\title{
Recommendation of Neurorehabilitation according to the Padovan-Method Neurofunctional Reorganisation $\circledast$ for treating neurodevelopmental disorders: a systematic review
}

Dimitri Vogel born Eisenmeier ( $\sim$ dimitri.vogel@uni-wh.de )

University of Witten/Herdecke: Universitat Witten/Herdecke https://orcid.org/0000-0003-0629-5893

Thomas Ostermann

University of Witten/Herdecke: Universitat Witten/Herdecke

Hannah Vogel

University of Witten/Herdecke: Universitat Witten/Herdecke

Kathrin Loskamp

University of Witten/Herdecke: Universitat Witten/Herdecke

Katharina Fetz

University of Witten/Herdecke: Universitat Witten/Herdecke

Research article

Keywords: neurological rehabilitation, neurodevelopmental disorders, rehabilitation of speech and language disorders, systematic review

Posted Date: March 10th, 2021

DOI: https://doi.org/10.21203/rs.3.rs-301600/v1

License: (c) (1) This work is licensed under a Creative Commons Attribution 4.0 International License. Read Full License 


\section{Abstract}

Background: The PADOVAN-METHOD NEUROFUNCTIONAL REORGANISATION® is a promising approach in speech therapy for treating neurodevelopmental disorders of traumatic or congenital origin. Its use is based on a long-time experience of certified therapists; however, its efficacy and safety has not yet been assessed in a systematic review. This report aims to gain evidence for the use of the therapy method.

Methods: Guidelines of PRISMA, the Cochrane Collaboration Handbook, MECIR and GRADE were followed. General databases (Cochrane Library, PubMed, AWMF, Anthromedics) and additional 38 databases including grey literature were searched. Hand search was also done and experts were contacted to retrieve unpublished manuscripts. All trials investigating the effect of the method in comparison to either no intervention, alternative as state of the art or placebo intervention in English, Portuguese and German language were included. No restriction regarding study design was applied. Data related to the intervention outcome and the study method was extracted and analysed idependently. Risk of Bias was assessed using ROBINS-I for non-RCTs, adherence to CAREGuidelines was analysed for case series or reports and keeping the Declaration of Helsinki was checked for all items. Results are presented both in evidence profiles and summary of findings tables according to GRADE.

Results: Amongst 98 records assessed for eligibility, and four studies and 14 case reports were identified as appropriate for analysis with a total of $n=196$ participants. Duration of reported interventions was between two days and two years. Microcephalia, down-syndrome, unspecified neurological disorders and myo-functional disorders were the main conditions of the patients with neurodevelopmental disorders. Only indirect overlapping of operationalised criteria was found; therefore conclusions are limited.

Conclusion: The Padovan-Method $\AA$ is a holistic therapy approach claiming feasibility to a large group of disorders making proof of efficacy difficult. An application of therapy according to the Padovan-Method ${ }^{\circledR}$ by trained therapists might be considered by clinicians (weak recommendation), and a contribution to the relief of symptoms or improvements of the conditions might be gained. Therefore, development and validation of therapy protocols and further investigation are required. PROSPERO Registration: CRD42020156124.

\section{Introduction}

\subsection{Background}

For treating orofacial dysfunctions regarding closure of mouth, tongue position and speech development in early childhood, the AWMF guideline ( $22 k$ ) for down syndrome in childhood and adolescence within the AWMF-framework (Association of Scientific Medical Societies; 1 ) names several therapy options. The Padovan-Method Neurofunctional Reorganisation ${ }^{\circledR}$ (short: Padovan-Method $\AA ; 2$ ) is one of the listed therapy options amongst others like Castillo Morales ${ }^{\circledR}$ Concept [3], NEPA (neurophysiological developmental formation) according to Pörnbacher, 2009 [4] and F.0.T.T. $®$ (Facio-oral-tract-therapy ${ }^{\circledR}, 5$ ). Whilst several studies regarding the Castillo Morales ${ }^{\circledR}$ Concept are presented and its application recommended in guidelines for children with abnormal mouth function or tongue protrusion [1], the Padovan-Method $\circledast$ only remains mentioned with no hint to efficiency [1].

The relevance and usefulness of oral myofunctional therapy in temporomandibular disorders was recently investigated and approved in a systematic review [6] and recommended as an early intervention $[1,7]$. The Padovan-Method $\AA$ is frequently used in children and young patients with myofunctional disorders [8]. This was shown in an inquiry by Ruben \& Wittich, 2014 [8], who gained expert evidence for the treatment of myofunctional disorders by reviewing existing therapy concepts ( $n=536$ experts) [8]. In this report, the Padovan-Method $\circledast$ is the second most used approach after the therapy according to Kittel [8]. Remarkably, Kittel herself recommends applying the Padovan-Method® alongside the self developed approach [9].

\subsection{Description of the intervention.}

The Padovan-Method $\AA$ was developed as a holistic approach by the speech therapist and waldorf school teacher Beatriz A. E. Padovan in the 1970s, integrating a broad range of neurological functions also described by Abad Bender, 2017 [10]. It is a rehabilitative approach in newborn, children and adults with neurodevelopmental disorders. Some information about the method can be found online [11-13] provided by the umbrella organisation of the PadovanMethod $\AA$ (Brazil)[1]. Older sources can also provide some aspects of the therapy [16-18]. The use of the Padovan-Method $\AA$ has been recorded in different countries such as Brazil, Canada, Germany, France, Spain, Greece and Switzerland amongst others [19].

Since no handbook exists covering both the theoretical approach and guidelines to the therapist, describing the model of intervention according the PadovanMethod $\circledast$ remains challenging. The UK society provides a digital brochure [19] on the method, and some details are described by Abad Bender, 2019 [20]. The concept is presented as a program which involves the entire body, hands, eyes and mouth $[19,20]$. Physiological movement patterns of ontogenetic development processes would serve as orientation [20], and adherence to rhythm and a change between tense and relaxation can be important characteristics $[19,20]$.

The concept is based on

- interdependencies of anthropological development phases and a rule-like running through development stages $[10,12,13,21]$ and

- neuroplasticity, its trainability and the idea to initiate, regulate and strengthen elementary functions and motions using movement exercises in a multidisciplinary setting in order to facilitate the progress of speech development as well as sensorimotor and higher cognitive functions [12, 20, 22].

Even if the assumption of functional and structural neuroplasticity is not new as a basic idea, the number of publications has risen considerably in recent years[2] and can be considered a fact more than a theory [23]. Mechanisms of neuroplasticity [24, 25] and its intervention-dependent trainability in the context 
of early brain lesions as well as rehabilitation after brain damage [26-29] are under examination. In poststroke patients, neuroplasticity has been shown [30] and a systematic review indicates the presence of neuroplasticity following intervention in children with congenital hemiplegia [31].

Assuming the presence of neuroplasticity [20, 22, 28, 32-34], this method can be seen as a combination of whole body physio- and logopaedic speech therapy $[10,35]$ following a hierarchic set of units addressing entire body systems (motoric functions of hands, arms and legs, coordination, arbitrary and automatic movements, reflex system), as well as mouth functions (breathing, suction, chewing, swallowing) [9, 36, 37], as well as considering sensory body and cognitive functions. Part of the concept is based on myofascial chains and their interconnection between different parts of the body [10, 38, 39]; details regarding the mouth-function-units can be found published by the founder [18]. One of the core aspects of the method is to accomplish the development to the upright by repeating the physiological development stages, i.e. roll, crawl, pull up and walk. [10, 16, 21, 40-43].

This construct leads to an a multi-indication suitability where study approaches regarding breathing and sleep apnoea [44, 45], sucking and feeding condition in preterm new-born babies [22, 46-48], myo-functional disorders [49] and also congenital syndromes [44, 47, 50-55] could be found. A contextualisation to other therapy approaches is beyond the scope of this article and can be found in publications by Jasmin, Beauregard, \& Tetreault, 2012, Finkbeiner, 2008 and Bergt, Kurtenbach, \& Finkbeiner, 2017 [39, 56, 57]. The target group of the Padovan-Method ${ }^{\circledR}$ includes patients of all ages following curative, supportive or preventive aims $[20,22,39,47,48,58]$.

Due to missing therapy guidelines, no clear information about the principal intervention design is available. Existing literature indicates a protocol with therapy sessions of 45-60 minutes each ranging from 2-7 times a week for a period of several weeks up to several months [10,35, 59] or even longer up to three years [60]. A certain set of equipment is required for the intervention and described by Abad Bender, 2017 [10], among others: climbing frame ('Padovan Stair'), hammock chair, self developed lounge-type chair ('Padovan Chair'), ortodontic elastics (rubber-ring), medical latex tube, oblate, pacifier, whistle, flute, party blower, spatula and scarf. The Padovan-Method ${ }^{\circledR}$ can be applied by people with healthcare degree [19], mainly logopaeds, physiotherapists, ergotherapists and osteopaths who have completed a multi-step qualification programme [19,61-63]. The Padovan-Method® is used in is used in hospitals as well as in therapists' private offices $[22,48]$.

\subsection{State of the art and description of the condition}

The Padovan-Method $\AA$ has only been published incompletely [18], and no comprehensive therapy guide is available. Nevertheless the concept was recently described exemplarily by Abad Bender, 2017 and 2019 [10, 20], Pereira, 2015 [22] and Treuenfels, 2003 [21].

The target patients of the therapy are those with neurodevelopmental disorders such as motoric impairment, language, learning and behavioural alterations, orofacial disorders leading to dysphagia and additionally other complications caused by brain damage, syndromes or other congenital reasons [12, 20-22, 35, $64,65]$. For a definition of neurodvelopmental disorders see Cioni, Inguaggiato, \& Sgandurra, 2016 [66]. The method appears in a few scientific publications in patients with orofacial or myofunctional disorders (dysphagia, closure of mouth, tongue position and speech development in early childhood; $21,67-70$; also related to down syndrome; 1 ; lack of coordination of sucking, breathing and swallowing; 22, 48), and neurological disfunctions or developmental disorders with different origin (autism; 43, 71; cerebral palsy; 48; microcephalia; 51-53, 72, stroke; 73; fatigue as well as mental and physical disability; 20, 39, 74, 75; habits; 76). A small increase of scientific publications including information on its effectiveness can be found in the past decade [48, 49, 55, 77-81].

\subsection{Why it is important to do this review}

The Padovan-Method $\AA$ remains a relatively unknown therapy approach. Data about the Padovan-Method $\AA$ is thin or not scientifically substantiated [10, $82-$ 84]. The non-academic background of the therapists (logopaeds, physiotherapists, ergotherapists; 10) might be one of the reasons for the lack of available trials. Whereas Starrost \& Schilling, 2013 [70] lists the approach in an overview article of therapy approaches in dysphagia [70], no publication concerning the Padovan-Method® met the inclusion criteria for a systematic review focusing interventions for oropharyngeal dysphagia by Morgan, Dodrill, \& Ward, 2012 [85].

In view of the burden of the targeted groups of patients, more evidence regarding potentially appropriate therapy methods is highly desired. An abstract anouncing a literature review about the Padovan-Method $\AA$ and its evidence was found [86]. Continuing or updating existing reviews is recommended by literature [87]. As no results of the announced review were available or published, we decided to develop this systematic review regarding the effectiveness of the Padovan-Method ${ }^{\circledR}$ which, to our knowledge, is the first on this topic. Adherence to the Preferred Reporting Items for Systematic Review and Meta-Analysis (PRISMA, 88), TheCochrane Collaboration Handbook [89], the Guidelines of the Grading and Recommendations Assessment, Development and Evaluation working group (GRADE, 90) and in parts to Methodological Expectations of Cochrane Intervention Review (MECIR, 91) was considered in the design.

\subsection{Objective}

This systematic review aims to discuss available scientifically published studies or case reports on the explicit application of a therapy according to the Padovan-Method ${ }^{\circledR}$ on newborns, children and adults. Due to the explorative character of this project, design restrictions regarding the included studies were dispensed. Both experimental studies and observational designs were of interest. Studies with either no intervention, alternative intervention as state of the art or placebo intervention were included. It is sought to clarify the application spectrum and effectiveness of the Padovan-Method® to gain evidence of usability.

\section{Methods}


While guidelines for creating systematic reviews in rehabilitative medicine have been nonexistent, guidelines are currently being worked out by the Cochrane Rehabilitation Group and the creation of recommendations is ongoing [92]. Future updates to this review will be able to take currently unavailable guidelines into account [92]. For now, available concepts were obeyed [93] to ensure methodologic quality [94] by following the available guidelines of PRISMA [88], TheCochrane Collaboration Handbook [89], MECIR in parts [91] and GRADE [90]. The review has been registered at PROSPERO database (registration number: CRD42020156124). A protocol following PRISMA-Protocols (PRISMA-P) [95] was developed and is currently under review [96].

\subsection{Eligibility criteria}

As the context of the Padovan-Method $\AA$ refers to rehabilitative medicine, difficulties were present [97] in setting up a PICOT search strategy (Patient problem, Intervention, Comparison, Outcome and Time, [93]) as needed for a systematic review [98]. Scientific reports on efficacy of the Padovan-Method $\AA$ meeting the hereinafter defined PICOT question were included.

\subsubsection{Participants.}

To define the target group ( $P$, patient) a set of relevant diagnoses for the Padovan-Method® would be needed but is not clearly provided by existing literature. Consequently, $P$ was set broadly as the following: All studies examining newborn, children and adults regardless sex and age (i) in a neuro-rehabilitative setting due to neuropsychomotoric disfunctions or development disorders, OR (ii) with orofacial or myofunctional disorders, OR (iii) with any other not yet listed diagnosis will be included.

\subsubsection{Intervention.}

All designs using the Padovan-Method ${ }^{\circledR}$ were of interest. If another treatment was applied in conjunction, those reports were included too. The interventions had to be applied by trained therapists [63]. No further limitations were set for duration of each therapy session, frequency and overall duration of the intervention.

\subsubsection{Comparators.}

With regard to the wide area of the intended review, several comparators were set. Comparison with either no intervention, alternative intervention as state of the art or placebo was analysed.

\subsubsection{Outcome.}

Consequently, the outcome $(O$, outcome $)$ is widespread and was likewise wide set, considering this review aims to investigate expectable results presented in existing studies. Improvement of condition or allevation of symtoms were of interest. Response to treatment regarding motoric functions, psychomotor development, speaking, swallowing and eating as well as suction were defined as primary outcomes. Definitions of outcomes were extracted as reported in the included studies. A list of rating instruments used in the included trials is presented in this review.

\subsubsection{Timing.}

Items were included regardless of length of intervention or follow up. This was decided due to expected little available data.

Summarizing, the following PICOT question was formulated: "In newborn, children and adults patients regardless sex and age (i) in a neuro-rehabilitative setting due to neuropsychomotoric disfunctions or development disorders, OR (ii) with orofacial or myofunctional disorders, OR (iii) with any other not yet listed diagnosis $(P)$, how does an application of the Padovan-Method $\circledast$ by trained therapists $(I)$ compared with either no intervention, alternative intervention as state of the art or placebo intervention $(C)$ affect the existing symptoms and quality of life $(O)$ within what time $(T)$ ?"

A recommendation for an updated PICOT question with special regards to $P$ and $O$ was developed.

\subsubsection{Study design.}

As a pilot search revealed, little data was available and no randomised controlled trials (RCT) were found [99]. This is not a rare situation in rehabilitation research [92, 97], and eligibility therefore was set to include all types of qualitative and quantitative intervention reports. Included items were RCTs, controlled (non-randomised) clinical trials (CCTs), cluster trials, controlled before-after (CBA) studies, prospective and retrospective comparative cohort studies and casecontrol, nested case-control studies (CCS) as well as case series (CS) and case reports (CR).

\subsubsection{Language.}

We conducted the search in English and included all results in English, as well as Portuguese and German, were taken in. Titles in other languages were identified and listed for further consideration. 


\subsubsection{Publication status.}

Scientific documents regardless their publication status (published, in preparation or unpublished manuscripts) were included.

\subsection{Information sources}

The publication search was carried out within general databases (MEDLINE via PubMed, Cochrane Library, AWMF, Embase, Epistemonikos, UpToDate, BIREME, SciLEO, DARE, SAGE, Scopus, SpeechBite, EBSCO/Ovid (CINAHL, Psyndex, TOC Premier, E-Journal Database, Psyclnfo, PsycArticles, PsycBooks)), and complementary and alternative medicine (CAM)-based databases [100] (Cambase, Otseeker, PEDro, Anthromedics). Additionally, clinical trial registers (CTR) were scanned (Cochrane Central Register of Controlled Trials CENTRAL, ISRCTN registry, WHO CTR, ANZCTR, Brazilian CTR, ChiCTR, ClinicalTrials.gov, India CTR, EU CTR, PACTR), as well as PROSPERO to find ongoing or recently completed trials/reviews. According to the protocol of this review [96], a hand search as well as grey literature was conducted to retrieve more relevant data [101-103]. Therefore, relevant databases were used (Google Scholar, GoogleBooks, Open Grey, NTIS, AHRQ, Gray Source Index, OpenDOAR). We inspected the references of all identified studies for more results. Additionally, we contacted the Society of the Padovan-Method $\AA$ Brazil $[14,15]$ and Germany [62] to identify further studies or missing information.

\subsection{Search strategy}

Regarding the thin data the search term was set up using "padovan" in title or abstract. It was adapted, as necessary, for each database. Exemplary, the term used in Cochrane Library was padovan[title] OR padovan[abstract]. The search was conducted from June 2019 until end of November 2019 . Some delay occurred during the project due COVID-19.

A re-run of the search prior to the final analysis (MEDLINE, Embase via Cochrane Library and PsycINFO) was carried out in August 2020.

\subsection{Study records}

\subsubsection{Data management.}

Results from different sources were collected in Excel first and duplicates removed by finding identical titles. MAXQDA (version 2018, Verbi GmbH) was used for data extraction and content analysis. Citavi (version 6, Swiss Academic Software GmbH) was used as a reference manager.

\subsubsection{Selection process.}

After removal of duplicates (DV), titles and abstracts of the remaining results were screened independently by two reviewers for further duplicates and eligibility check (DV, HV). In the case of disagreement, a third reviewer was consulted (TO). Ongoing, all selected items were retrieved if possible as full text to be fully analysed (DV) to identify those to be included in the systematic review.

\subsubsection{Data collection process.}

Data was extracted based on princples of PRISMA [88]. Further data extraction for study quality and ethical evaluation was based on ROBINS-I (a tool for assessing risk of bias in non-randomised studies of interventions,104, 105), the CARE-Guidelines [106] and the items proposed by Weingarten, Paul, \& Leibovici, 2004 [107]. For further description of ROBINS-I and CARE see section Study quality and risk of bias (section 2.6).

A standardised form and detailed instruction manual was developed (DV), piloted (DV), and introduced and explained to the second reviewer (KL). Authors of articles for which no full text was available or any other important data was missing were contacted electronically if contact details were identifiable.

\subsection{Data items}

Data was extracted with respect to reference, status of publication, country (where the treatment was carried out) , sample (number of participants), drop out, groups, blinding (if any), age of participants, diagnosis/indication (characteristics of the participants), diagnostic instruments, research design of the treatment study, duration per session $\left(D_{\mathrm{s}}\right)$, frequency, duration of overall intervention period $\left(D_{\mathrm{o}}\right)$, therapist (qualification) and main outcome, specification of the numerical result being assessed, length of follow-up, confounding domain(s), measured treatment outcome variable(s), co-Intervention(s). Consensus was sought in case of disagreements and if necessary, a third reviewer was consulted (HV). Relevant information for assessing ethical considerations, the study quality and risk of bias was extracted in the same work flow (see section Study quality and risk of bias and Ethical considerations).

\subsection{Outcomes}

Outcomes in the setting of rehabilitative medicine evidence are difficult to define [97]; therefore, little restriction regarding sought outcomes was given. All outcomes and data were extracted as reported (e.g. dichotomous, continuous). 


\subsubsection{Primary outcomes.}

Due to the explorative character of the current review, a list of outcomes could not be given in advance. Improvements of motoric functions, psychomotor development, speaking, swallowing and eating as well as suction were relevant. Expectable results by the Padovan-Method $\AA$ are presented in the results section, which can be used for further updates of the review. In terms of clarification of the potential outcomes, which might report various time points of the trial, we have decided to subdivide treatment indices as follows:

i. early response, between one and four weeks

ii. acute phase treatment response between six and 12 weeks

iii. follow-up response between four and six months

\subsubsection{Secondary outcomes.}

Secondary outcomes were set according to GRADE [90] as follows:

i. number of and reasons for dropping out of studies

ii. death

iii. adverse side-effects

iv. contra indications (i.e. certain conditions or diagnosis)

The number of drop-outs was used to define the acceptability of treatment and tolerability. Indicators regarding quality of life were extracted if available and taken into account in the summaries of findings tables.

\subsection{Study quality and risk of bias}

To assess the quality and risk of bias, we followed the recommended of the Cochrane Collaboration [89] and used ROBINS-I [104, 105] by two reviewers (DV, KL). ROBINS-I [104] uses different domains to assess the risk of bias: (1) bias due to confounding, (2) bias in selection of participants, (3) bias in classification of interventions, (4) bias due to deviations from intended interventions, (5) bias due to missing data, (6) bias in measurement of outcomes, (7) bias in selection of the reported result and (8) overall bias. The assessment was documented in a table and explanations given in the case of serial or critical risk of bias, and was assessed per study rather than per outcome [108]. To make these judgements, we used the criteria listed in ROBINS-I [104] for judging low risk, moderate risk, serious risk and critical risk of bias. See Table A1 (Appendix A) for the definition of each domain and for a description of the overall bias judgment both described by Sterne et al., 2016 [104]. For further quality assessment the adherence of case reports to the CARE-Guidelines [106] was judged instead. The CARE-Guidelines outline advise concerning the following domains: Keywords, Abstract, Introduction, Patient information, Clinical findings, Timeline, Diagnostic assessment, Therapeutic interventions, Follow-up and outcomes, Discussions, Patient Perspective [106]. According to Sanderson, Tatt, \& Higgins, 2007 [109], no scoring but only descriptive reports on adherence to CARE have been done [109]. Retraction statements and errata were checked if available for further information of limitation or potential exclusion[91]. As no RCTs were available, RoB 2 (Cochrane Collaboration tool for assessing the risk of bias; 110) was not applied.

\subsection{Data synthesis}

A model of how the intervention works was set up in the first step according to the findings.

Studies are described textually following the guidelines on the conduct of narrative synthesis in systematic reviews [111] and details of all included items are presented tabulated to develop a preliminary synthesis of the results.

To evaluate relationships in the data, studies were grouped according to similar characteristics.

\subsection{Meta-bias}

In order to evaluate if reporting or publication bias is present $[88,112]$, we determined whether protocols of studies are available and published before the start of the study. In case of included abstracts reporting about intended studies, we documented if the results are published to evaluate whether the results were reported as planned.

\subsection{Confidence in cumulative estimate}

To judge the quality of the evidence for all important outcomes GRADE methodology [90] was used. GRADE recommends evaluation of the quality of evidence of the outcomes by assessing the domains of risk of bias, consistency, directness, precision and publication bias before summarising the overall response to treatment, acceptability of treatment (drop-out due to any reason), quality of life, death, overall tolerability [90]. To define the overall quality of evidence and assigning grades we used the definitions according to GRADE [113]; also see Table A2 and A3 (Appendix A). GRADE evidence profiles (EP, 90) were set up to 
provide information on outcomes of each subgroup. The main findings were presented as 'Summary of findings'-tables providing relevant information regarding the quality of evidence, the effect of the interventions and the sum of available and included data on the main outcomes $[90,108,113-115]$.

\subsection{Ethical considerations}

No approval of an ethical committee for a systematic review was required as no patient data is processed.

Included trials were checked if they were approved by an ethics committee and informed consent was given. The ethical standard of all items and adherence to the Declaration of Helsinki [116] was outlined. See Table A4 (Appendix A) for the hereby used checklist for ethical assessment of trials in systematic reviews as proposed by Weingarten et al., 2004 [107].

Studies were included even though adherence to ethical standards were poor or simply not reported. This was done to reveal possible risk of bias due to unpublished trials [117] and to bring light in the little-noticed field of research regarding the Padovan-Method®.

\section{Results}

A total number of $n=533$ items were found using scientific databases ( $n=229)$, grey literature databases $(n=233)$, trial registries $(n=2)$ and other sources $(n$ = 69). See Table B1 (Appendix B) for a list of the databases used and the number of results. After removal of duplicates $(n=114)$, a total number of $n=419$ items were screened for titles and abstracts and exclusions were made where necessary $(n=321) .98$ titles were analysed for eligibility and exclusions $(n=$ 80) were made according to the protocol [96] for missing full text $(n=4)[78,79,81,86]$, whereas three of them were abstracts of relevant trials [78, 79, 81], and one of them was an announced review of the Padovan-Method $\AA$ [86]. The authors were contacted but no further full text was available. Other items did not meet inclusion criteria but contained information about basic principles of the Padovan-Method ${ }^{\circledR}(n=22)$ as primary literature $(n=8)[16,40-42,118-$ 121] or secondary literature $(n=14)[10,35,39,59,60,65,122-129]$, recommended the Padovan-Method $\circledast$ in a context-dependent manner $(n=29)[1,18,20$, $43,56,67,69,71,73-76,80,84,130-144]$, mentioned the therapy as a possible option for certain indications without any proof of evidence $(n=10)[7,70,83$, 145-151] or simply contained some unspecified information about the method $(n=7)$ [82, 152-157]. Due to manuscript language, eight potentially relevant items had to be excluded [37, 77, 158-163]. See Table B2 (Appendix B) for a reference list of excluded items. Finally, four studies (no RCT, one pseudo-RCT [49], one non-RCT/CCT [55], one CBA [44] and one retrospective self-compared cohort study [48]) and $n=14$ case documentations (10 CR [46, 47, 50-53, 72, 164-166] and 4 CS $[22,36,54,167])$ remained for inclusion. Divergent from the protocol, no further exclusion was made in the case of CS or CR with unclear documentation of the therapists qualification (therapy under supervision $[52,53,72]$ or $\mathrm{NI}[50,51,54,164-166])$. A flowchart following the PRISMA guidelines [168] was created to illustrate the process and is shown in Fig. 1. The characteristics of the sample are shown in Table 1 and an overview of the quantitatively evaluated primary outcomes is given in Table 2 .

Table 2. Table of primary outcomes quantitatively evaluated

\section{Primary outcomes}

early response, between one and four weeks

decrease of $\mathrm{DI}_{90}[44]$ acute phase treatment response between six and 12 weeks

changes of tongue- and lip coordination exercises [49]

swallowing examination [49]

position of tongue-tip whilst swallowing [49]

position of tongue edge whilst swallowing [49]

articulation (s-sound formation[169]) [49]

time to get up in the morning [170] long-term and follow-up response between four and six months (or more)

improvement condition of lips [36]

reduced habit of

- licking lips [36]

- biting objects [36]

improved

- sitting posture [36]

- swallowing patterns, [36]

improved axis symmetry of

- eyes, [36]

- zygomatic bone[36]

- shoulders. [36]

gained as ability

- pull the lips wide[36]

- move the tongue to the right or in a circle [36]

reduced lateral posture [36]

no preferred side of chewing [36]

rise of the AIMS Score [171] [54] 


\subsection{Study quality and risk of bias}

The risk of bias using ROBINS-I [104, 114] is presented in Table 3. See Tables D2-D5 (Appendix C) for details and authors judgement. Although [49] described the design as a pseudo-randomised controlled trial, it was not clear, to what extent it could be interpreted as randomised or non-randomised; therefore, we classified and rated it as non-RCT.

Table 3. Risk of bias ROBINS-I of the included studies

\begin{tabular}{|c|c|c|c|c|c|c|c|c|}
\hline $\begin{array}{l}\text { Author / } \\
\text { Year }\end{array}$ & 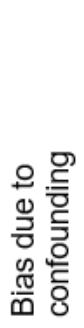 & 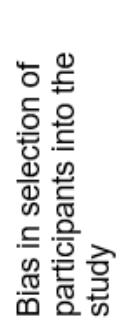 & 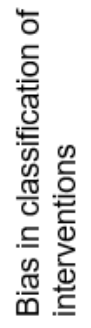 & 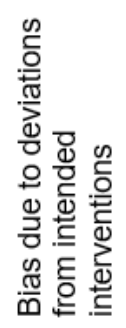 & 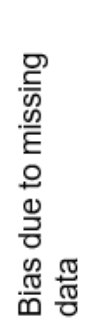 & 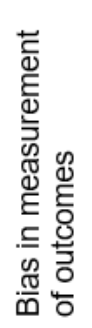 & 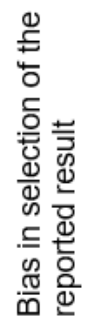 & 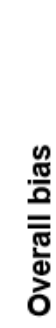 \\
\hline \multicolumn{9}{|l|}{$\begin{array}{l}\text { Bellingen } \\
2017 \text { [49] }\end{array}$} \\
\hline \multicolumn{9}{|l|}{$\begin{array}{l}\text { Lukowicz } \\
2019 \text { [44] }\end{array}$} \\
\hline \multicolumn{9}{|l|}{$\begin{array}{l}\text { Pereira et } \\
\text { al. } 2015 \text { [48] }\end{array}$} \\
\hline $\begin{array}{l}\text { Rodenacker } \\
2007 \text { [55] }\end{array}$ & & & & & & & $?$ & \\
\hline
\end{tabular}

Notes. Assessment according to the ROBINS-I tool [104]

+ low risk of bias. ? moderate risk of bias. $\times$ serious risk of bias. 1 critical risk of bias.

None of the included studies had a low risk of bias; two items were at moderate [44] or serious [49] risk of bias, and two other items had a critical risk of bias $[48,55]$. Bias due to confounding was present due to too short study design [44] and multi-therapy setting [48, 55]. Selection bias occurred due to retrospective design and selection into the study in relation to intervention [48]. Bias in classification of interventions was overall at low risk. Deviations from intended interventions caused moderate risk of bias due to un-balanced co-interventions $[48,55]$ and critical risk of bias due to potential effect of not controlled cointerventions [48]. Missing data for any participant led to a critical risk of bias [48]. Unclear conditions in measurements of outcomes were rated with moderate risk of bias due to observers knowledge of the intervention $[48,49]$ and serious risk of bias due to language barriers, limited condition of patients at certain measurements [55], and no available outcome data [48]. Bias in selection of reported results were detected as moderate bias due to no available study protocol [48, 49,55], serious due to deviations between methods and results section [49], and critical due to rare outcome data in the results section [48]. Limitations were set according to the overall risk of bias, if no further limitations existed. Imprecision was judged according to GRADE ${ }^{[113]}$ (see Table 4).

Table 4. Quality of evidence regarding risk of bias, limitations and imprecision 


\begin{tabular}{|llll|}
\hline Author (Year) & Risk of bias $^{\text {a }}$ & Limitations $^{\text {b }}$ & Imprecision $^{\text {b }}$ \\
\hline Bellingen 2017 [49] & serious risk & moderate & low \\
\hline Lukowicz 2019 [44] & moderate risk & low & very low \\
\hline Pereira et al. 2015 [48] & critical risk & high & high \\
\hline Rodenacker 2007 [55] & critical risk & high & moderate \\
\hline Barbosa 2019 [50] & - & high & high \\
\hline Braga 2019 [51] & - & high & high \\
\hline Buson 2019 [52] & - & high & high \\
\hline Carmo 2019 [53] & - & high & high \\
\hline Delmondes 2018 [47] & - & high & high \\
\hline Froitzheim 2010 [164] & - & high & high \\
\hline Großweischede 2000 [165] & - & moderate & high \\
\hline Kunert 2003 [166] & - & moderate & high \\
\hline Menezes 2019 [54] & - & moderate & moderate \\
\hline Oertel 2015 [36] & - & moderate & moderate \\
\hline Oliveira 2019 [72] & - & moderate & high \\
\hline Pereira 2015 [22] & - & high & high \\
\hline Pereira 2018 [167] & - & high \\
\hline Wilson 2016 [46] & - & moderate & \\
\hline
\end{tabular}

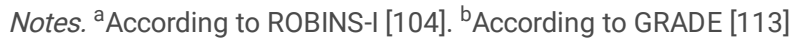

The results of the CARE [106] evaluation of the CS and CR were evaluated as shown in Table 5. No retraction statements were found. One CS was found including an erratum as appendix with some corrections of the manuscript (master thesis), taken into consideration by this work [36]. None of the included CS and CR completely fulfilled the CARE [106] recommendations. Critical limitations were present in all items regarding at least one of the following domains: 'Diagnostic assessment' [22, 47, 50-53, 164], 'Follow-up and outcomes' (all items) [22, 36, 46, 47, 50-54, 72, 164-167] and 'Discussion' [47, 50-53, 72, 164, 166]. Limitations of CS and CR where therefore considered to be moderate [36, 46, 54, 72, 165-167] or high [22, 47, 50-53, 164]. For an overview, see also Table 4.

\subsection{Ethics assessment}

Approval by an ethics committee was reported only in two papers [54, 172]; the results are summarised in Table 6. No information about agreement was found in all other items $[22,36,46-53,55,72,164-167]$. Patient informed consent given prior to the intervention was documented in four of the results [36, 48, 54, 165]. Lukowicz et al., 2019 [44] reported no patient informed consent had been required. Documentation was unclear in one case [166] and no information was found in the remaining items $[22,46,47,49-53,55,72,164,167]$.

\subsubsection{Funding.}

Only one item reported on sources of funding and stated to not have received any funding [44].

\subsubsection{Declaration of interest.}

Only one item had a declaration of interest declaring none [44].

\subsection{Textual descriptions of included items and reported outcomes}

The included studies and case reports are described textually in this section, providing general information about the setting, participants, indicating diagnoses, intervention, comparisons, variables and outcomes. If applicable, further information is presented in the Table 1.

\subsubsection{Studies.}


The included studies [44, 48, 49,55] covering the period from 2007 to 2019 were found published [44, 48, 49] or as grey literature [55]. For two of the published studies $[44,49]$, detailed underlying thesis manuscripts were available as grey literature $[45,170]$, which were used to gain further information about the studies. Three of the studies were carried out in Germany [44,55] and one in Brazil [48]. The setting was either clinical (inpatients) [44, 48] and ambulatory [49, 55], and the number of participants reanged from $n=10$ [55] to $n=92$ [48] and was $n=156$ in total. The age of the participants reached from 2 days [48] to 15 years [49]. Amongst the prospective trials [44, 49,55], a controlled setup was found in two cases [49, 55], one trial was retrospective, self-controlled and descriptive [48]. Indicating diagnosis were down syndrome [55], down syndrome with obstructive sleep apnoea [44], myo-functional disorders [49] and newborns with symptoms summarised as alterations in neurological examination or presenting difficulties in sucking [48]. Nevertheless, myo-functional disorders were also present in the three other studies in included patients $[44,48,55]$. Study drop-outs $(n=35)$ were reported due to upper respiratory infections, recording of less than three hours of sleep $(n=24$ [44]), death due to sepsis in the context of new-born $(n=7$ [48]), transfer $(n=2$ [48]), surgery $(n=1$ [48]) or too large off intervals between therapy sessions $\left(n=1\right.$ [49]). All therapists were documented to be qualified for the Padovan-Method ${ }^{8}$ [63]. The measured items were entirely heterogeneous without any conformity. The rating instruments used in the included papers are listed in Table C1 (Appendix C). Rodenacker, Ivdal, \& van Amsterdam, 2007 [55] used the motoric test (MOT 4-6[173]), speech development test ('Sprachentwicklungstest' SETK 3-5 [174]) and a parental questionnaire regarding the development of the participants and their influence on the family, self-developed by Rodenacker et al., 2007 [55]. Pereira et al., 2015 [48] documented and evaluated neurological examinations [48]. Bellingen, 2017 [49] used the lowa Oral Performance Instrument (IOPI) [175], assessment of mouth closure by therapists using a three point scale, lip strength using the MFT-'Lippenwage' (tool to strengthen and measure the muscles for closure of lip and mouth [176]), measurement of suction power and speed using the suction trainer developed by Beatriz A. E. Padovan and described at Abad Bender, 2017 [10], coordination of tongue and lips using certain tasks from a toolkit developed by and described at Kittel \& Förster, 2010 [177], swallowing examination using a own system with different types of fluid and colour [170], observation of teeth and jaw position by therapists [170], Bruininks-Oseretsky Test of motoric proficiency (BOT-2) [178], articulation ('Lautprüfbogen' LPB, [169]), therapists observation and parents questionnaire developed by the author described at Bellingen, 2017 [49] with the following items: time needed for homework, concentration during homework, difficulties with orthography, difficulties with building sentences, difficulties with finding the right words, building unstructured sentences, time to get up in the morning, awakening during night, needed time to fall asleep, preference of certain food-consistency, chewing [49]. Lukowicz et al., 2019 [44] used the mixed-obstructive-apnoea/hypopnoea index (MOAHI, 44, 45, defined as the sum of obstructive and mixed apnoea and hypopnea per hour of corrected estimated sleep time[1] (CEST) 44, 45), DI 3 (desaturation index $\geq 3 \%$, events per hour of corrected estimated sleep time [44, 45]), $\mathrm{Dl}_{90}$ (desaturation index $<90 \%$, events per hour of corrected estimated sleep time $[44,45])$, arterial oxygen saturation (SpO) [44].

In all studies, the core intervention were therapy sessions according to the Padovan-Method $\AA$. The duration of the sessions were 45 minutes [44, 49] (NI: [48, 55]), with application frequency varying in all studies between three times a day [44], five times per week [48], two times per week [49] and in one case accelerating from one to two times per week [55].The intervention periods were heterogeneous with one week [44], 10 weeks [55], 11 weeks [49] and due the retrospective setup two days to five months [48].

The trials resulted in heterogeneous outcomes. Statistically significant changes of tongue- and lip coordination exercises (tongue exercise 2 [177] likelihoodratio test (LR) $x^{2}(2, n=12), p=0.001$ [49]; lip exercise 1[177]: LR $\left.x^{2}(n=12), p=0.005\right)$ [49], swallowing examination (swallowing fluids[170] t-Test for independent samples: $t(10)=-5.331, p<0.000$ [49], position of tongue-tip whilst swallowing[170] $\mathrm{t}-$ Test for independent samples: $t(10)=-3.429, p=0.006$ [49], position of tongue edge whilst swallowing [170] t-Test for independent samples: $t(10)=-9.163, p<0.001$ [49]) [49], articulation (s-sound formation[169] t-Test for independent samples: $t(10)=-2.525, p=0.010)[49]$ and time to get up in the morning (parental questionnaire, Chi-square test $x^{2}(3, n=12, p=0.023)[170]$, decrease of $\mathrm{DI}_{90}(2,7(S D 4.5)$ to $2.1(S D 3.7) \mathrm{p}<0.05)$ [44]. Not statistically significant, but described as noticeable, was an increase of lip strength (MFT-'Lippenwage'[176] T1 = initial examination: 500-1017g; T2 = examination after intervention: 850-1367g) [49], and a subjective boost of development described by some of the parents [55]. No data provided, and thereby only descriptively reported, were the following: a shortening of hospital stay, avoidance of gastrostomy and palliative procedure of feeding for discharge of the treated new-borns [48]. Furthermore, no statistically significant effect of the PadovanMethod ${ }^{\circledR}$ on obstructive sleep apnoea in down syndrome patients was shown [44], and no difference between therapy methods according to PadovanMethod $\circledast$ and Psychomotor Performance Therapy was revealed [55]. Moreover, a change of the tongue pressure, lip strength, suction power and speed, quality of mouth closure, physiologically swallowing of food, fine and gross motor skills was not shown or not evaluable due to small sampling size [49]. None of the studies had a follow-up testing or documentation.

\subsubsection{Case Reports.}

The included case reports $[22,36,46,47,50-54,72,164-167]$ covering the period from 2000 to 2019 were found as described above for other studies used. Nine of the cases were collected in Brazil [22, 47, 50-54, 72, 167], three in Germany [36, 165, 166], one in Great Britain [46] and one did not provide any information about the country [164]. The context of the cases were university [51-53, 72], inpatients $[22,46,47,54]$ and ambulatory setting $[36,165,166]$ (no information provided $[50,164,167])$. The number of participants ranged from $n=1$ to $n=11$ [22] and was $n=40$ in total. The items contained four case series $[22,36,54,167]$ and ten single case reports $[46,47,50-53,72,164-166]$. The age of the participants ranged between five days [22] to 28 years [46]. Indicating diagnosis were microcephalia (with total $n=14$ in six case reports [50-54, 72]), neonatal hypoxic-ischemic encephalopathy ( $n=10$ [22]), myo-functional disorder $(n=8$ [36]), foetal alcohol syndrome ( $n=2$ [167]), neurological alteration by kernicterus $(n=1$ [22]), speech development disorder $(n=1$ [166]), audiogenic dyslalia ( $n=1$ [165]), treacher collins syndrome $(n=1$ [47]), tetra paresis and open bite $(n=1$ [164]) and brain injury ( $n=1$ [46]). Study drop-outs ( $n$ = 5) were reported in one case series due to lack of time to adhere to the therapy protocol [36]. The therapists were either certified for the Padovan-Method $\AA$ $[22,36,46,47,167]$, under supervision $[52,53,72]$ or had no information provided $[50,51,54,164-166]$.

The measured items were heterogeneous without any conformity. See Table C1 (Appendix C) for the rating instruments utilized. (Menezes, Menezes, Lopes, Pereira, \& Tabosa, 2019 [54] used the Alberta Infant Motor Scale (AIMS [171]) and dichotomous assessment of physical assessment (grab objects, reflux, don't follow objects, lack of cervical control, convulsion/spasm, lack of thoracical control [54]) analysed descriptively. Oertel, 2015 [36] used a logopaedic

Page $10 / 66$ 
assessment tool developed for quality assessment in logopaedic therapies ('Kölner Diagnostikbogen' described at [180]), the report sheet from the results and progress log for neurofunctional reorganization ('Befund- und Verlaufsprotokoll zur Neurofunktionellen Reorganisation' IPVP [129, 181]) and a clarification of therapeutic objectives sheet ('Therapeutische Auftragsklärung' following [180]). The case report of Wilson, Dhamapurkar, \& Rose, 2016 [46] is mainly descriptive, but the used tools were the Wessex Head Injury Matrix (WHIM [182]) and the JFK Coma Recovery Scale-Revised (CRS-R [183]), and throughout the hospital stay replaced by the Putney Auditory Comprehension Screening Test (PACST [184]), the Functional Assessment Measure (FAM [185]) and the Functional Independence Measure (FIM [186]). No information about measured variables was given in any other item $(11)[22,47,50-53,72,164-167]$.

Within all reports, patients received therapy sessions according to the Padovan-Method®. The duration of each session was 45-60 minutes [36, 46, 51, 52, 72, $166]$ or not specified [22,47,50,53,54, 164, 165, 167], with application frequencies of 1 or 2 times per week $(1-2 / w)$ [36, 46, 54, 72, 165], 5-6/w, [47, 53] and 7/w [50-52] (NI: [22, 164, 166, 167]). The intervention periods were between five days [47] and two years [165] (NI: [46]). In some case reports, other therapies were applied too and are to be accounted as confounding domains (kinesiology [51, 52], osteopathy or physiotherapy [36], multi-disciplinary setting [46], use of a lip-cheek-tongue trainer ('Lippen-Wangen-Zungen (LWZ)-Trainer' [187]) [36], manual therapy not further specified [50]).

The reports presented again heterogeneous results. Statistically significant changes were presented in two case reports [36, 54], though had moderately imprecise documentation according to GRADE Rating [188]. Fisher's exact test [172] and Wilcoxon Test [189] was used to measure statistical significance between first and third (last) examination [36] and revealed the following results: no preferred side of chewing $(p=0.025)$, condition of lips ( $p=0.024)$, pull the lips wide gained as ability $(p=0.046)$, move the tongue to the right or in a circle gained as ability (each $p=0.046)$, reduced habit of licking lips $(p=0.034)$, habit of biting objects reduced $(p=0.038)$, improved sitting posture $(p=0.046)$, reduced lateral posture $(p=0.020)$, improved swallowing patterns $(p=0.026)$, improved axis symmetry of eyes $(p=0.038)$, zygomatic bone $(p=0.025)$ and shoulders $(p=0.026)$. A rise of the AIMS Score ([171]) between the first and third testing was described and postulated as statistically significant without a provided confidence interval (t-Test $t(8)=2.927, p=0.19 \mathrm{Cl}$ : NI, [54]) [54].

Not statistically significant but noticeable effects such as reducing dysphagia and bronchial aspirations, spasms, improvement of the abilities to roll, crawl and sit were reported [54], albeit imprecisely [188]. An improvement of the body condition (tone, posture, axial symmetry, occurrence of tension and pain) was qualitatively described as observed changes between initial and final testing [36]. A rise of the CRS-R [182] from three (T1: 4 months post injury, equal to vegetative state [183]) to eight (T2: 14 months post injury) was documented [46]. Throughout the hospital stay of the reported case, CRS-R [183] and WHIM [182] were discontinued because of ceiling both tests [46] followed by measuring PACST [184], FAM [185]) and FIM [46, 186] with no further information regarding development of numbers. A high bias of missing data (according to GRADE [190]) exists as only results of the CRS-R [183] are reported [46]. Progress in verbal expression and improvement in cognition and speech within a multimodal therapy setting was qualitatively reported [46].

No other reports provided any measurements, but reported improvements in the fields of psycho- and motoric development, speech and vegetative functions. Details are listed in Tables D20 and D21 (Appendix C). One report described a case but did not contain explicit results [166]. One of the reports mentioned a follow-up after 3 years without detailed testing showing improved motorial and speech development (high risk of bias due to confounding domains: physiotherapy and speech therapy as no Padovan-Therapy ${ }^{\circledR}$ had been available) [47].

The results of the studies and case reports were used to define the primary and secondary outcomes (see Table 2 and Appendix C Tables D20-21). Statistically significant outcomes are listed separately (see Table 2). To extract the early response from acute phase treatment, response the length of intervention was used (cut-of duration of treatment process $\leq 1$ month [22, 47, 48, 55, 167] and $\leq 3$ months for acute phase treatment [22, 49-53, 167], > 3 months for longterm response [36, 46, 47, 54, 72, 164, 165]). As some of the included trails or reports extended over a long period, by derogation from the protocol [96], the section 'follow-up response between four and six months' was extended to 'long-term and follow-up response between four and six months and more'. Secondary outcomes in the case of drop-outs were listed in the Table C21 (Appendix C). The reported deaths in seven cases [48] were caused by sepsis of preterm babies. No adverse side effects or contra indications were found in any of the included trials or reports.

\title{
3.4 Evaluation of relationships and subgroup analysis
}

Despite possible methodological weaknesses in the included items, relationships and subgroup analysis were evaluated for diagnosis, outcomes, comparison and duration of the intervention.

There was some accumulation of leading diagnoses in of the studies:

\author{
i. microcephalia $[50-54,72]$ \\ ii. down-syndrome $[44,55]$ \\ iii. neurological disorders (high heterogeneity) $[22,44,46-48,50-55,72,164-167]$ \\ iv. myo-functional disorders $[36,44,48,49,55]$
}

Due to a heterogenic setting and inclusion criteria (addressing inconsistency [191]), differences in study population, intervention protocol, and measured outcomes (addressing indirectness [192]), a comparison or subgroup analysis for indication diagnoses cannot expect a high or moderate ranking according to GRADE-Guidelines [90]. Nevertheless, a GRADE evidence profile (EP) [90] was set up for I-IV regarding the outcome 'condition improvement or alleviation of symptoms'.

Additional analysis of the potential outcomes of the studied therapy approach was carried out with consideration of the limitations, risk of bias and methodological weaknesses. Therefore the three domains of outcomes formulated in the initial PICOT question [96] (see the introduction) were addressed:

A. motoric dysfunction

Page 11/66 
B. neuropsychomotoric development disorder

C. oro-facial or myo-functional disorder

D. any other not yet listed diagnoses

By analysing the outcomes (see Tables 2 and D21 of Appendix C), it is found that speech or articulation difficulties are addressed several times and was therefore set as separate type of outcome (D). For each of the outcome domains (A-D), several primary outcomes (see Table C21 of Appendix C) can be assigned, whereas each primary outcome can be assigned to one or more outcome domains. Mapping all primary outcomes led to a subdivision of (A) into (A.i) motoric development and coordination and (A.ii) posture and axial symmetry impairment. (C) contains (IV) as per inclusion criteria, and was the destination for all outcomes in the context of swallowing or eating, excluding speech or articulation, as this was domain (D). Table C22 (Appendix C) shows the assignment of the primary outcomes and the relevant papers. The GRADE evidence profiles (EP) [90] for each subgroup are listed in Tables 7 (I-IV) and 8 (A-D).

Regarding the comparison of intervention, little data is available, as most of the included papers do not provide a control group or placebo. To their credit, developing a placebo for hands-on therapy is challenging. Only two of the included studies had a control group [49, 55], and all other items have to therefore be considered observational studies in terms of GRADE-Evidence rating [90].

The outcome of the PICOT question 'modify the existing symptoms and quality of life within what time' contains the treatment duration as a variable. Within the included studies, the duration of the applied therapy varied greatly, reaching from few days to multiple years. Outcomes were qualitatively described as partly emerging already after a few therapy sessions with additional results visible after at least a few months (see Tables 2 and D20 of Appendix C). Building subgroups for further analysis was not considered due to heterogeneity, very serious indirectness [192] and inconsistency [191].

\subsection{Confidence in cumulative estimate}

The EP of (I), (II), (III) and (A-D) summaries of findings according to GRADE [90] are shown in Tables 9 (I), 10 (II), 11 (III) and 12-15 (A-D). (IV) is not presented separately as included in (C) (Table 14). A downrating was inevitable in all items due to inconsistency, indirectness, imprecision and risk of bias regarding an evaluation of evidence and in most of the cases, due to study design, small sample sizes, heterogeneity and methodological weaknesses. The absence of a large magnitude effect, dose response in more than one item or confounders minimizing the effect in more than one item an uprating was not to be considered. Consequently, the GRADE quality rating [113] was very low for every defined item (very uncertain about the estimate of effect). This might confuse involved therapists and trainers, but should be seen in the scientific context and high standard of evaluation this review is based on. This is not intended for discouragement but rather to encourage future research and study design with high quality standards. Table 16 contains the derived PICOT recommendations for clinicians.

\subsection{Meta-bias}

Publication bias is present and possibly serious. During the research process, announcements for trials [81], trial reports [78, 79] and a systematic review [86] were found as conference poster or abstracts without any hint for full-text publication. Requests for more information provided no further data. Even though 14 of the included items were published, only three of the included items were found through database research (MEDLINE via PubMed [44], Embase [166], EBSCO/Ovid TOC Premier [49]), whereas all others were found searching grey literature, cross-reference or offline research throughout a network of therapists. The language used by the authors was English only in six cases [22, 44, 46-48,55]. The accessibility of many items was restricted, aside from the included items composed in Portuguese [50-54, 72, 167] or German [36, 49, 164, 165]; other items were only available in French [37, 77, 158-162] or Spanish [163].

Outcome reporting bias is present but difficult to estimate, no study protocol or trial register was found. In two cases of published articles [44, 49] a prior thesis manuscript was available $[45,170]$ to provide more information on outcome as in the final article. Deficits in presentation of results were present in a large number of included items (see Tables 3-5).

\subsection{PICOT Recommendation}

The PICOT question was used to build recommendations regarding the included studies, case reports and analysis of the data considering the EP and SoF of each outcome (see Tables 8-15 and Table 16 Appendix Large Tables).

[Placeholder Table 16. Clinical recommendations]

\subsection{Updated PICOT-question}

Derived from results of the review and the information from the umbrella organisation of the Padovan-Method® (Brazil) [12], an overview of the target group $(P)$ can be set as stated in Table C23 (Appendix C), adding information from articles identified through research process but not included into the analysis due to research character $[10,21]$.

The updated PICOT review question for further research is presented in Table C24 (Appendix C). 


\section{Discussion}

\subsection{Summary of main results}

The Padovan-Method ${ }^{\circledR}$ is a rehabilitation approach used for neuro-rehabilitation globally. Its effects in general, compared to other therapies or placebo has, to our knowledge, not yet been assessed by a systematic review. Moreover, the number of available studies about the method is very low. In this work, a total of $n$ $=18$ reports and $n=196$ participants indicate a possible contribution to a relief of symptoms or improvements of condition, mainly in the context of mouth functions (swallowing, lip and tongue movement).

\subsubsection{Clinical implications.}

The available material now provides substance for strong recommendations, showcasing the absence of adverse effects, the resolution of symptoms and the reported improvements of quality of life are as desirable outcomes [193]. As shown in Table 16 (Appendix Large Tables), in all listed symptomclusters (A-D) or diagnoses (I-III) application of therapy according to the Padovan-Method® by trained therapists might be considered by clinicians (weak recommendation) and a relief of some symptoms might be possible within a time span from a few days to 24 months.

For all recommendations, further research is highly recommended to reduce the uncertainty.

\subsubsection{Evaluation of side effects and contraindications.}

Study quality and methodology implicate a reporting bias on potential side effects and contraindications of the therapy approach. The included studies provide poor information on the presence of side effects or contraindications (see Table C21 of Appendix C), and a considerable amount of participants dropped out due to infection reasons ( $n=24$ upper respiratory infections [44], $n=7$ sepsis [48]). The data presented in the studies is too thin and does not provide any epidemiological context, making comparisons to general numbers difficult. Further, it is imperative to consider the cases of death. As the recruiting of patients was done within a neonatal intensive care unit [48], higher mortality rates compared to population in general is possible. Additionally, reference numbers are difficult to draw in, as many details and the place of study are not clear or not provided. In a study from 2018 carried out in Brazil, a neonatal mortality rate with sepsis involvement reported 2.3 deaths per one thousand live births [194]. Given this context, the mortality in the cited study [48] appears high and further explanation would have been highly desired.

Even though no contraindications for the application of the Padovan-Method® were found in the included trials or reports, precaution is required in the case of broken bones. According to oral presentations during the annual conference of the German Padovan-Method® association (2019), instability and fracture of dens axis alike other spine instability are strict contraindications to the therapy.

\subsubsection{Acceptability.}

The available data provides only limited information about acceptability of the treatment, as comparison is difficult due to the fact of missing control groups in most of the included studies. $n=40$ drop-outs due to any reason in $n=187$ treated patients (213 drop-outs per 1000) can be considered an indicator for acceptability and compliance, although it presents a very indirect measurement.

\subsection{Overall completeness and applicability of evidence}

Although most of the included studies are published, only a small number of items underwent a peer review. Reliability and applicability of the results remain unclear, underlined by the fact, that the study with the lowest risk of bias [44] (see Table 3) presented only a marginal effect.

We emphasise that there is not sufficient information on side-effects and contraindications in the included material. It remains open if these outcomes were not measured or not reported, as protocols are not available.

\subsection{Quality of evidence}

As it is difficult to develop trials in rehabilitative medicine especially with high level of evidence [97], it was not surprising, that there was not RCTs amongst the included results. Nevertheless, an adherence to recommendations for trial setup and reporting could be expected, but revealed methodological flaws in most of the included items. Outcome measurement was difficult to compare due to different rating instruments used. The presentation of results was also sometimes narrative. Concluding, according to our 'summary of findings' Tables (I-III), the evidence on 'response to treatment' was very low, 'overall tolerability', 'acceptability of treatment' was only moderate, 'quality of life' was low, and no sufficient data on the other a priori defined outcome of the 'Summary of findings' tables, 'death due to intervention side effects' was provided.

\subsection{Agreements and disagreements with other studies or reviews}

To our knowledge, no systematic review has investigated the effect of therapies according to the Padovan-Method®. Neto, José Ribeiro da Silva et al., 2016 [86] published an abstract stating a planned review, but it was not found to be published. Several articles or hints are found published promoting positive 
effects of the Padovan-Method $\AA$ [1, 18, 20, 43, 56, 67, 69, 71, 73-76, 80, 84, 130-144], though without providing underlying studies. Ruben et al., 2014 [8] present results of an expert inquiry for treating myo-functional disorders where the Padovan-Method® was the second most used approach [8], and Klocke, Korbmacher, \& Kahl-Nieke, 2000 [7] claim a multidisciplinary approach referring to the ideas of the Padovan-Method $\circledast$ in the context of treating myo-functional disorders [7]. Starrost \& Schilling, 2013[70] list and explain several methods for treating dysphagia including the Padovan-Method $\circledast$ [70] enumerated also by the AWMF guideline for down syndrome in childhood for treating orofacial dysfunctions regarding closure of mouth, tongue position and speech development in early childhood [1].

Nevertheless, critical voices are also present. Candel \& Bonilla, 2016 [82] provide an informational brochure about the Padovan-Method $®$ in the context of down syndrome, ultimately advising against the method [82] due to lack of evidence. Suchodoletz mentions the method in several of his works [83, 84, 143, $150,151]$ and criticises the theoretical fundament of the method as outdated, and is critical of the method due to missing evidence of its effectiveness in learning disabilities [83]. One of the included studies suggests nearly no effect, ableit limitations were given due to too short intervention protocol [44]. This systematic review comes to the conclusion, that the Padovan-Method $\circledast$ might be considered by clinicians if indicated, and a relief of some symptoms might be possible, but further research and higher quality studies are necessary (see Table 16 Appendix Large Tables).

\subsection{Authors conclusions}

This systematic review was developed to establish preliminary evidence on the use of the Padovan-Method®. Considering the little available literature about the method, its potential outcomes or suggested treatment protocol, the inclusion criteria of this review were wide-ranging allowing for the exploration of multiple facets of this particular approach.

Summarizing this review, the Padovan-Method ${ }^{\circledR}$ therapy approach is observed in several small-scale studies and case reports. Methodological weaknesses were present in all items and accordingly rated or commented in the text. Whilst there were more studies not fulfilling the inclusion criteria, the included material allows at least a weak recommendation for the Padovan-Method $\AA$ in patients with certain neuro-rehabilitative needs with a possible alleviation of symptoms.

No statement can be given regarding the theoretical framework and model of intervention as it remains a theoretical concept, and its proof was not the intent of this work and further investigation on this method is incumbent to large-scale studies.

Thus a need for higher-grade methodological studies is indispensable to gain certainty what patients benefit most from the Padovan-Method®. In conducting up new trials, special attention should be paid to the methodological challenges in rehabilitative medicine [195]. The selection of outcomes and relevant measurements, definition of intervention protocol and handling with drop-outs or missing data can enable a comparison of results between studies in order to gain more certainty regarding evidence.

For measuring neurodevelopmental outcomes, standardised and validated tests should be considered according to the age of the target group. Exemplarily named might be the Bayley Scales of Infant and Toddler Development, Third Edition [196], the McCarthy Scale of Children's Abilities (MCSA) [197] or Raven's Coloured Progressive Matrices and Trail Making Tests [198] as exemplarily described and applied by Karakosta, Margetaki et al. [199], SETK 3-5 [174], PACST [184] amongst others.

An adherence to a methodological framework, such as CONSORT [200] or CONSORT extensions for adaptive designs [201], adaptation for N-of-1 [202] or rehabilitation medicine [203] as well as CARE-Guidelines [106, 204] for case reports or the STROBE statement for observational studies (cohort, case-control studies, cross-sectional studies) [205] is highly recommended. This includes reporting on received funding and declaring competing interests, which was rare in papers on hand.

According to the little reporting on ethical considerations or adherence to the Declaration of Helsinki [116], it is inevitable to point out that further studies have to improve on reporting on ethical aspects. Using the work of Weingarten et al., 2004 [107] can help on this issue.

Regarding clear therapy description and how-to manuals further research is necessary and it is strongly recommended to present more details on duration, frequency and intervention period of the therapy. The author's group in this systematic review is currently working on a delphi process to gain a treatment recommendation [206]. The knowledge of experienced trainers is needed. a subsequent set of studies will be required to proof the recommendations.

Regarding the training and certification process of the Padovan-Method® some clarifications are necessary. There seem to be no restrictions to take part and complete the certification courses; hence a basic qualification in the therapeutic area should be the minimum to ensure quality and safety of the therapeutic process.

\subsection{Patient and public involvement}

There is no patient and public involvement in the conduction of this systematic review. It is for use for academic and clinical audiences, patients' associations and policy makers. Guideline developers may be influenced in order to improve outcomes for patients according to review results.

\subsection{Limitations}


Limitations are given due to the difficulties of evidence in rehabilitative medicine and missing concepts [92, 97]. The small available scientific background of the therapy approach made it difficult to set up a well dfined PICOT Question.

The language restrictions led to further reduction of included items.

The inclusion of studies despite the poor reporting on ethical standards has to be considered critically, but may help to improve further investigation projects. Updates of this systematic review should handle this topic more stringently.

There was a small amount of available data and deficient reporting, as in many cases, study results were not precisely documented. Results were partly incomplete and contained methodologic flaws. Classification of the items were often difficult due to unclear design, population or outcomes. Inconsistency, indirectness and publication bias made clear outcomes difficult. These aspects hindered drawing precise conclusions.

The described drop-outs due to death caused by sepsis in preterm new-born intensive care babies [48] should be examined more closely and put in relation to general mortality numbers.

More research is highly recommended and might have an impact on the confidence of evidence of the therapy according to the Padovan-Method ${ }^{\circ}$.

\section{Abbreviations}

- AIMS, Alberta Infant Motor Scale

- amb, ambulant

- AWMF, Association of Scientific Medical Societies

- BOT-2, Bruininks-Oseretsky Test of motoric proficiency

- BRA, Brazil

- C, comparator

- $\mathrm{c}$, in children

- CAM, complementary and alternative medicine

- CARE, Consensus-based clinical case reporting

- CBA, controlled before-after study

- CCS, nested case-control study

- CCT, controlled (non-randomised) clinical trials

- CEST, corrected estimated sleep time

- $\mathrm{Cg}$, control group

- ci, co-interventions

- $\mathrm{Cl}$, confidence interval

- CONSORT, Consolidated Standards of Reporting Trials

- CR, case report

- CRS-R, JFK Coma Recovery Scale-Revised

- CS, case series

- CT, computer tomography

- CTR, clinical trial registers

- d, days

- de, German

- DI, desaturation index

- $D_{O}$, duration of overall intervention

- $D_{S^{\prime}}$ duration of each intervention session

- EEG, electroencephalogram

- en, English

- EP, evidence profile

- O.T.T.®, Facio-oral-tract-therapy ${ }^{\circledR}$

- FAM, Functional Assessment Measure

- FIM, Functional Independence Measure

- GBR, United Kingdom of Great Britain and Northern Ireland

- GER, Germany

- GRADE, Grading and Recommendations Assessment, Development and Evaluation working group

- I, intervention 
- e., that is to say

- Ig, intervention group

- ip, inpatient

- impr, improvement of motoric functions

- IOPI, lowa Oral Performance Instrument

- IPVP, ‘Befund- und Verlaufsprotokoll zur Neurofunktionellen Reorganisation'

- LPB, 'Lautprüfbogen'

- LR, Likelihood Ratio

- LWZ, 'Lippen-Wangen-Zungen (LWZ)-Trainer' / lip-cheek-tongue trainer

- $M$, mean

- m, months

- MECIR, Methodological Expectations of Cochrane Intervention Review

- MOAHI, mixed-obstructive-apnoea/hypopnoea index

- MOT, 'Motoriktest' / test of motoric function

- MRI, magnetic resonance imaging

- $\mathrm{N}$, no

- $n$, sample size

- NEPA, neurophysiological developmental formation

- newb, new-born

- NI, no information provided

- NR, not relevant

- O, outcome

- P, patient

- $p$, $\mathrm{p}$-value

- PICOT, Patient problem, Intervention, Comparison, Outcome and Time

- PN, partly no

- PRISMA, Preferred Reporting Items for Systematic Review and Meta-Analysis

- PRISMA-P, Preferred Reporting Items for Systematic Review and Meta-Analysis protocols

- progr, progress

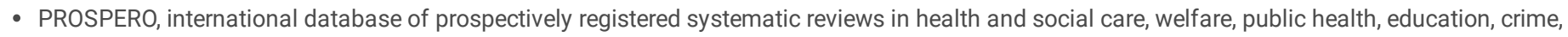
justice, and international development, where there is a health related outcome

- pt, Portuguese

- pub, published

- PY, partly yes

- q, qualified

- RCT, randomised controlled trials

- RoB 2, Cochrane Collaboration tool for assessing the risk of bias

- ROBINS-I, tool for assessing risk of bias in non-randomised studies of interventions

- $S D$, standard deviation

- SETK, 'Sprachentwicklungstest' / speech development test

- SoF, summary of findings

- SpO, arterial oxygen saturation

- STROBE, STrengthening the Reporting of OBservational studies in Epidemiology

- $t$, t-Test

- T1, initial examination

- T2, examination after intervention

- univ, university

- unp, unpublished

- w, weeks

- WHIM, Wessex Head Injury Matrix

- $x^{2}$, chi-squared

- $y$, years 
- $\mathrm{Y}$, yes

\section{Declarations}

\section{Ethics approval and consent to participate}

Not applicable.

\section{Consent for publication}

Not applicable.

\section{Availability of data and materials}

All data generated or analysed during this study is included in this published article and its supplementary information files.

\section{Competing interest}

The authors declare that they have no conflict of interests.

\section{Support}

The project team received support in form of access to articles and grey literature by experts of the Society of the Padovan-Method $\AA$ Brazil and the German association of the Padovan-Method®

\section{Funding}

This systematic review did not receive any funding

\section{Authors' contribution}

DV and KF developed the search strategy. DV performed systematic searches, screened titles and abstracts for duplicates and was the major contributor in writing the manuscript. Screening for eligibility was done by DV and HV. KL was implicated as a second independent reviewer of the literature. DV and KL extracted the data. HV and KF were consulted as third reviewers in case of disagreement. TO had an advisory function and mainly contributed to structure the manuscript. All authors read and approved the final manuscript.

\section{Acknowledgments}

Our thank goes to the following persons or institutions for providing difficult to find literature. N. Abad-Bender, I. Bezerra Costa, G. Finkbeiner, S. Padovan, H. v. Treuenfels, Society of the Padovan-Method $\AA$ Brazil and the German Association of the Padovan-Method ${ }^{\circledR}$.

Many thanks to: Prof. Dr. Thomas Ostermann and M. Sc. Katharina Fetz for their care and supervision, Prof. Dr. Friedrich Edelhäuser for his important suggestions.

My warmest thank goes to my beloved Hannah.

\section{Amendments}

If amendments to the protocol [96] were necessary, we will note the date of each amendment as well as the description of the change and the rationale in this section.

\section{Date of most recent amendment.}

01 September 2020

\section{Date of most recent SUBSTANTIVE amendment.}

01 September 2020 


\section{What's New.}

Due to the Sars-CoV-2 pandemic there are delays in the process and the schedule therefore had to be changed. Further restrictions were also made regarding the included studies. Only studies in English, Portuguese and German will now be included.

Conference abstracts were not included because they could not provide sufficient information.

The EPPI reviewer was not used due to difficulties in functionality and compatibility of operating platforms.

As some of the included trails or reports extended over a long period, by derogation from the protocol [96], the section 'follow-up response between four and six months' was extended to 'long-term and follow-up response between four and six months and more'.

The assessment of reporting on ethical standards was expanded according to [107] and [117] as the analysis of the included trials revealed relevant shortcomings on this topic.

\section{References}

1. Rohrer T, Jung A-M, Muche-Borowski (Methodik/AWMF) C, Wilken E, Mehl B, Hammersen G, et al. Down-Syndrom im Kindes- und Jugendalter: Konsensbasierte Leitlinie (S2k) der Deutschen Gesellschaft für Kinder- und Jugendmedizin (DGKJ) und der beteiligten Fachgesellschaften, Berufsverbände und weiterer Organisationen. AWMF online www.awmf.org/leitlininien/detail/Il/027-051.html. 2016.

2. Padovan BAE. Neurofunctional reorganization in myo-osteo-dentofacial disorders: complementary roles of orthodontics, speach and myofunctional therapy. J Matern Fetal Neonatal Med. 1995;21:33-40.

3. Türk C, Brockmöller K, editors. Das Castillo-Morales-Konzept: 5 Tabellen. Stuttgart: Thieme; 2012.

4. Pörnbacher T. Kau-, Trink- und Schluckstörungen im Säuglings- und Kindesalter. In: Böhme G, Benecke P, editors. Sprach-, Sprech-, Stimm- und Schluckstörungen. 4th ed. München: Elsevier Urban \& Fischer; 2009. p. 367-391.

5. Nusser-Müller-Busch R. Die Therapie des Facio-Oralen Trakts: F.O.T.T. nach Kay Coombes. 3rd ed. Berlin, Heidelberg: Springer-Verlag Berlin Heidelberg; 2011.

6. Melis M, Di Giosia M, Zawawi KH. Oral myofunctional therapy for the treatment of temporomandibular disorders: A systematic review. Cranio. $2019: 1-7$. doi:10.1080/08869634.2019.1668996.

7. Klocke A, Korbmacher H, Kahl-Nieke B. Der Status der myofunktionellen Therapie im Rahmen der interdisziplinären Zusammenarbeit aus der Sicht des Muskelfunktionstherapeuten. Sprache · Stimme · Gehör. 2000;24:38-43. doi:10.1055/s-2000-11066.

8. Ruben L, Wittich C. Evidenzbasierte Behandlung Myofunktioneller Störungen. Forum Logopädie. 2014;28:22-9.

9. Kittel AM. Myofunktionelle Therapie. 11th ed. Idstein: Schulz-Kirchner Verlag; 2014.

10. Abad Bender N. Myofunktionelle Therapie in der Padovan-Methode®: Neurofunktinelle Reorganisation. Sprachtherapie aktuell: Forschung - Wissen Transfer: Schwerpunkthtema: Intensive Sprachtherapie (4). 2017:1-18. doi:10.14620/stadbsl171109.

11. Histórico - Método Padovan®. 2020. https://metodopadovan.com/historico/. Accessed 29 Aug 2020.

12. Aplicação - Método Padovan. 2020. https://metodopadovan.com/aplicacao/. Accessed 29 Aug 2020.

13. O Método - Método Padovan®. 2020. https://metodopadovan.com/o-metodo/. Accessed 29 Aug 2020.

14. Pró Sinapse | Núcle Didáctico Padovan - Brasilien. Dachorganisation der Padovan-Methode®. http://site.prosinapse.com.br. Accessed 20 Aug 2019.

15. Método Padovan®. 2020. https://metodopadovan.com. Accessed 29 Aug 2020.

16. Padovan BAE. Reorganização Neurofuncional-Método Padovan. Jornal Brasileiro de Ortodontia e Ortopedia Maxilar. 1997:3-11.

17. Padovan BAE. Dos Pés à Cabeça (Andar, Falar e Pensar). Chão e Gente. Instituto ELO de Economia Associativa, Botucatu-SP, set. 1997:9-10.

18. Padovan BAE. Reeducação mioterápica nas pressões atípicas de língua: diagnóstico e terapêutica. Revista ortodontia de São Paulo. 1976;9.

19. Salerno L. The Padovan Method $®$ UK - Training Program The most versatile holistic therapeutic approach. 2018. http://www.padovanmethod.co.uk/thepadovan-method/digital-brochure.html. Accessed 1 Aug 2020.

20. Abad Bender N. Die Padovan-Methode ${ }^{\circledR}$ : Neurofunktionelle Reorganisation in der Ergotherapie. Praxis Ergotherapie. 2019;32:142-9.

21. Treuenfels $\mathrm{H}$ von. Training natürlicher Muskelfunktionen. Die Neurofunktionelle Reorganisation (NRF) bei Cranio-mandibulären Dysfunktionen (CMD). GZM-Praxis und Wissenschaft. 2003;8:12-6.

22. Pereira LM. Padovan Method as Early Stimulation in Neonatal Intensive Care Unit. Internacional Archives Of Medicine 2015. doi:10.3823/1765.

23. Dan B. Neuroscience underlying rehabilitation: what is neuroplasticity? Dev Med Child Neurol. 2019;61:1240. doi:10.1111/dmcn.14341.

24. Gulyaeva NV. Molecular Mechanisms of Neuroplasticity: An Expanding Universe. Biochemistry Mosc. 2017;82:237-42. doi:10.1134/S0006297917030014.

25. Sailor KA, Schinder AF, Lledo P-M. Adult neurogenesis beyond the niche: its potential for driving brain plasticity. Curr Opin Neurobiol. 2017;42:111-7. doi:10.1016/j.conb.2016.12.001.

26. Zotter S, Haberlandt E, Gottwald T, Kaufmann L. Funktionelle Neuroplastizität bei zwei Jugendlichen mit ausgeprägten frühkindlichen strukturellen Hirnschädigungen. Zeitschrift für Neuropsychologie 2007. doi:10.1024/1016-264X.17.4.225.

27. Schlaug G, Forgeard M, Zhu L, Norton A, Norton A, Winner E. Training-induced neuroplasticity in young children. Ann N Y Acad Sci. 2009;1169:205-8. doi:10.1111/j.1749-6632.2009.04842.x.

Page $18 / 66$ 
28. Han K, Chapman SB, Krawczyk DC. Cognitive Training Reorganizes Network Modularity in Traumatic Brain Injury. Neurorehabil Neural Repair. 2019:1545968319868710. doi:10.1177/1545968319868710.

29. Kleim JA, Jones TA. Principles of Experience-Dependent Neural Plasticity: Implications for Rehabilitation After Brain Damage. J Speech Lang Hear Res. 2008;51:35. doi:10.1044/1092-4388(2008/018).

30. Gauthier LV, Taub E, Perkins C, Ortmann M, Mark VW, Uswatte G. Remodeling the brain: plastic structural brain changes produced by different motor therapies after stroke. Stroke. 2008;39:1520-5. doi:10.1161/STROKEAHA.107.502229.

31. Inguaggiato E, Sgandurra G, Perazza S, Guzzetta A, Cioni G. Brain reorganization following intervention in children with congenital hemiplegia: a systematic review. Neural Plast. 2013;2013:356275. doi:10.1155/2013/356275.

32. Williams PTJA, Jiang Y-Q, Martin JH. Motor system plasticity after unilateral injury in the developing brain. Dev Med Child Neurol. 2017;59:1224-9. doi:10.1111/dmen.13581.

33. Prosperini L, Di Filippo M. Beyond clinical changes: Rehabilitation-induced neuroplasticity in MS. Mult Scler. 2019;25:1348-62. doi:10.1177/1352458519846096.

34. Dimyan MA, Cohen LG. Neuroplasticity in the context of motor rehabilitation after stroke. Nat Rev Neurol. 2011;7:76-85. doi:10.1038/nrneurol.2010.200.

35. Hoke F, Abad Bender N. Interview. Die Padovan-Methode. Friederike Hoke interviewte Nicole Abad Bender. Logos interdisziplinär. 2011;19:301.

36. Oertel F. Therapeutische Effekte der Padovan-Methode auf PatientInnen mit myofunktioneller Störung - eine Reihe von Einzelfallanalysen; 2015.

37. Ars C, Chaudoye-Kimmes A. Apports et limites de la méthode Padovan dans la prise en charge des troubles d'oralité des jeunes enfants porteurs de trisomie 21: étude de cas cliniques de trois enfants de 1 à 4 ans: En vue de l'obtention du Certificat de Capacité d'Orthophonie [Thesis]. Faculté de médecine Université Lille 2: Lille; 2013.

38. Richter P, Hebgen E. Triggerpunkte und Muskelfunktionsketten: In der Osteopathie und Manuellen Therapie. 4th ed. Stuttgart: Haug; 2015.

39. Finkbeiner G. Myofunktionelle Störungen Vergleich klassischer Ansichten mit der Neurofunktionellen Reorganisation nach Padovan [Diplomarbeit]. HalleWittenberg: Martin-Luther-Universität Halle-Wittenberg; 2008.

40. Padovan BAE. Die Entwicklung der Bewegung als Grundlage für die Sprache. Weleda-Nachrichten. 1982:11-4.

41. Padovan BAE. Réorganisation neurofonctionnelle (Méthode Padovan). Les cahiers de médecine anthroposophique. 1995:50-64.

42. Padovan BAE. Reorganização Neurofuncional - Método Padovan.: Temas sobre Desenvolvimento. São Paulo: Memnon - Edições científicas. 1994;17:13-21.

43. Lemer PS. Outsmarting autism: Updated and expanded : build healthy foundations for communication, socialization, and behavior at all ages. Berkeley, California: North Atlantic Books; 2019.

44. Lukowicz M von, Herzog N, Ruthardt S, Quante M, Iven G, Poets CF. Effect of a 1-week intense myofunctional training on obstructive sleep apnoea in children with Down syndrome. Arch Dis Child. 2019;104:275-9. doi:10.1136/archdischild-2018-315064.

45. Herzog NE. Polygraphische Evaluation des kurzfristigen Effekts der myofunktionellen Therapie bei Kindern mit Down Syndrom [Inaugural-Dissertation]. Tübingen: Eberhard Karls Universität zu Tübingen; 2018.

46. Wilson BA, Dhamapurkar SK, Rose A. Surviving Brain Damage After Assault: From Vegetative State to Meaningful Life. London: Taylor and Francis; 2016.

47. Delmondes EL de, Albuquerque LTCd, Pereira LM. Neurorehabilitation with Padovan Method in a Newborn with Treacher Collins Syndrome: A Case Report: A Case Report. AIMJ. 2018;3:1-7. doi:10.14295/aimj.v3i5.41.

48. Pereira LM, Vileicar DC, Sales SB, Alves, Maria do Socorro Landim Rodrigues, Pereira, Jamile de Melo Casado, Alves LML, et al. Padovan Method of Neurofunctinal Reorganization As a Way for Neurological Recovery in Newborns. Internacional Archives Of Medicine. 2015;8:1-6. doi:10.3823/1829.

49. Bellingen V. Wirksamkeit der Padovan-Methode® bei MFS. Forum Logopädie. 2017;31:16. doi:10.2443/skv-s-2017-53020170203.

50. Barbosa JS, Mota JS, Oliveira AKd, Braga CG, Rocha KQdS, Nascimento RPd, et al. Tratamento Fisioterapêutico Na Melhorada Qualidade De Vida De Pacientes Portadores De Microcefalia: Relato De Caso. In: Soares BM, Campanholi LL, editors. Fundamentos e Práticas da Fisioterapia 9: Antonella Carvalho de Oliveira; 2019. p. 181-188. doi:10.22533/at.ed.56519070321.

51. Braga CG, Rocha KQdS, Fonseca KKB, Barbosa JS, Mota JS, Belizario IMLdO. Relato De Caso: Intervenção Fisioterapêutica Em Paciente Com Microcefalia Congênita Por Zika Vírus. In: Soares BM, Campanholi LL, editors. Fundamentos e Práticas da Fisioterapia 9: Antonella Carvalho de Oliveira; 2019. p. 147-152. doi:10.22533/at.ed.56519070317.

52. Buson AIC, Amaral AFd, Oliveira AKd, Monteiro LS, Taddeo PdS, Paredes PFM, Belizário IMLdO. Verivicação Do Efeito Da Estimulação Precoce Em Criança Com Diagnóstico De Microcefalia Congênita Por Zika Vírus: Um Estudo De Caso. In: Soares BM, Campanholi LL, editors. Fundamentos e Práticas da Fisioterapia 9: Antonella Carvalho de Oliveira; 2019. p. 189-193. doi:10.22533/at.ed.56519070322.

53. Carmo CGd, Sampaio IO, Melo BLd, Aguiar PC, Monteiro NC, Belizário IMLdO. A Importância Da Fisioterapia Em Paciente Com Microcefalia Congênita Por Zika Vírus: Relato De Caso. In: Soares BM, Campanholi LL, editors. Fundamentos e Práticas da Fisioterapia 9: Antonella Carvalho de Oliveira; 2019. p. 16. doi:10.22533/at.ed.5651907031.

54. Menezes MIdN, Menezes MNdN, Lopes SMF, Pereira LM, Tabosa TÁCdN. Avaliação dos efeitos do método Padovan® no desenvolvimento neuropsicomotor de crianças com microcefalia: série de casos. Acervo Saúde. 2019:e1509. doi:10.25248/reas.e1509.2019.

55. Rodenacker K, Ivdal H, van Amsterdam H. Neurofunctional Reorganisation according to Padovan and Psychomotor Performance Therapy in children with Down Syndrome [Thesis]. Amsterdam: Hoogeschool van Amsterdam; 2007.

56. Jasmin E., Beauregard F., Tetreault S. Neuromaturationnal intervention approaches: Analysis of theoretical and scientific foundations. ANAE Approche Neuropsychol. Apprentiss. Enfant. 2012;24:76-85.

Page 19/66 
57. Bergt A, Kurtenbach S, Finkbeiner G. "SP1-Kinder" - Eine heterogene Diagnosegruppe. Praxis Sprache. 2017;62:201-8.

58. Lasagno AGS. O método Padovan TM de reorganização neurofuncional. In: Centro Reichiano \& Volpi Psicologia Corporal, editor; Curitiba: Centro Reichiano; 2014.

59. Moser-Dobis C. Neurofunktionelle Reorganisation - Die "Padovan Methode" als therapeutische Möglichkeit in der Sprachrehabilitation? Sprachheilarbeit : Fachzeitschrift für Sprachheilpädagogik und akademische Sprachtherapie. 2011;56:18-22.

60. Bucheli-Zemp I. Ein "merkwürdiger" Therapieansatz: Ganzheitliche Entwicklungstherapie mit Funktioneller Entspannung nach Marianne Fuchs und Neurofunktioneller Reorganisation nach Padovan. L.O.G.O.S. interdisziplinär. 2008;16:120-6.

61. ProLog Wissen. Padovan-Methode. 2016. https://docplayer.org/14078650-Padovan-methode-neurofunktionelle-reorganisation.html.

62. Gesellschaft der Padovan-Methode - deutschsprachiger Raum e.V. Gesellschaft der Padovan-Methode. http://padovan-gesellschaft.de/.

63. A Formação - Método Padovan®. 2020. https://metodopadovan.com/a-formacao/. Accessed 29 Aug 2020.

64. Pfeiffer S. Padovan-Therapeuten setzen sich für Qualitätssicherung ein. (German). Forum Logopädie. 2011;25:52.

65. Wennekers-Rodenacker M, Abad Bender N. Anmerkungen zum Artikel: „Neurofunktionelle Reorganisation - Die „Padovan-Methode" als therapeutische Möglichkeit in der Sprachrehabilitation" von Christine Moser- Dobis Sprachheilarbeit 56, 1, 2011, S. 18ff. Sprachheilarbeit : Fachzeitschrift für Sprachheilpädagogik und akademische Sprachtherapie. 2011;56:223.

66. Cioni G, Inguaggiato E, Sgandurra G. Early intervention in neurodevelopmental disorders: underlying neural mechanisms. Dev Med Child Neurol. 2016;58 Suppl 4:61-6. doi:10.1111/dmcn.13050.

67. Treuenfels H von, editor. Gesund beginnt im Mund: Warum Zähneknirschen zu Rückenschmerzen führt und Lachen den Blutdruck reguliert. München: Knaur MensSana; 2017.

68. Carbone Irujo L. Tratamiento Temprano de las Maloclusiones sin Aparatología Funcional: Presentación de Dos Casos Clínicos. Int. J. Odontostomat. 2014;8:253-60. doi:10.4067/S0718-381X2014000200018.

69. Hahn V, Hahn H. Myofunktionelle Störungen. In: Grohnfeldt M, editor. Lexikon der Sprachtherapie: Kohlhammer Verlag; 2007. p. $206-207$.

70. Starrost U, Schilling B. Therapiekonzepte in der Dysphagietherapie - ein Überblick. neuroreha. 2013;05:176-83. doi:10.1055/s-0033-1363037.

71. Limbrock J. Mundmotorik: Empfehlungen für Babys und Kleinkinder mit Störungen der oralen Funktion. Osteopathische Medizin. 2017;18:38-41. doi:10.1016/S1615-9071(17)30083-7.

72. Oliveira AKd, Nascimento RPd, Melo MPBd, Pinheiro AA, Buson AIC, Belizário IMLdO. Abordagem Fisioterapêutica em Paciente com Microcefalia Congênita por Zika Vírus: Relato de Caso. In: Soares BM, Campanholi LL, editors. Fundamentos e Práticas da Fisioterapia 9: Antonella Carvalho de Oliveira; 2019. p. 19-30. doi:10.22533/at.ed.5651907033.

73. Dhamapurkar SK, Rose A, Florschutz G, Wilson BA. The natural history of continuing improvement in an individual after a long period of impaired consciousness: The story of I.J. Brain Inj. 2016;30:230-6. doi:10.3109/02699052.2015.1094132.

74. Costa, lolanda Bezerra. O que é a Disfagia. 2017.

75. Montpetit L. Breaking Free from Persistent Fatigue. London: Jessica Kingsley Publishers; 2012.

76. Grohnfeldt M, editor. Lexikon der Sprachtherapie: Kohlhammer Verlag; 2007.

77. Gauthier C, Boudreault NL, Gilbert C, Perras H, Désilets J, Filiatrault A, Jasmin E. La méthode Padovan® de réorganisation neurofonctionnelle auprès des enfants présentant un trouble de l'acquisition de la coordination : une étude exploratoire mixte. Revue Francophone de Recherche en Ergothérapie 2016. doi:10.13096/rfre.v2n1.24.

78. Jutras AE, Boyer JA, Borduas V, Pandev-Girard B, Robitaille-Beaumier EL, Larivière N, Jasmin E. The Padovan ${ }^{\mathrm{TM}}$ Neurofunctional Reorganization Method: Exploring Its Application, Effects, and Appreciation in Children With Autism Spectrum Disorder [French]; 2012.

79. Millette C, Guillem F, Stip E. The Effects Of Neurofunctional Reorganization Therapy On Corporal Schema And Sensory Integration In Schizophrenic Patients: A PILOT STUDY. Schizophrenia Research. 2010;117:319. doi:10.1016/j.schres.2010.02.541.

80. Bäuml DM. Síndrom de Down: A Intervenção Humana e Tecnológica: Linguagem - Leitura - Excrita. Florianópolis; 2007.

81. Costa do Nascimento, Tereza Á, Pereira LM, Soares Dias P, Ferreira Lopes SM, das Neves Menezes, Maria Isabelle. Efeitos Do Método Padovan No Tratamento De Crianças Com Microcefalia. 2016. http://portal.estacio.br/media/5460/efeitos-do-método-padovan-no-tratamento-de-crianças-commicrocefalia.pdf.

82. Candel I, Bonilla C. El método Padovan...¿es recomendable?: opinión de los expertos en Atención Temprana de Down España. 2016. https://www.sindromedown.net/noticia/articulo-el-metodo-padovan-es-recomendable/. Accessed 14 Jul 2019.

83. Suchodoletz W von, Amorosa H. Therapie der Lese-Rechtschreib-Störung (LRS): Traditionelle und alternative Behandlungsmethoden im Überblick. 2nd ed. Stuttgart: Kohlhammer; 2006.

84. Suchodoletz W von. Sprech- und Sprachstörungen. Göttingen, Bern, Wien: Hogrefe; 2013.

85. Morgan AT, Dodrill P, Ward EC. Interventions for oropharyngeal dysphagia in children with neurological impairment. Cochrane Database Syst Rev. 2012;10:CD009456. doi:10.1002/14651858.CD009456.pub2.

86. Neto, José Ribeiro da Silva, Picanço KRT, Moreira YP, Andrade AC de, Oliveira CA de, de Almeida, Ariely Nunes Ferreira. Efeito do Método Padovan em Ambientes Clínicos:: Uma Revisão da Literatura. Cadernos de Educação, Saúde e Fisioterapia. 2016;3:18. doi:10.18310/2358-8306.v3n6supl.

87. Garner P, Hopewell S, Chandler J, MacLehose H, Schünemann HJ, Akl EA, et al. When and how to update systematic reviews: consensus and checklist. BMJ. 2016;354:i3507. doi:10.1136/bmj.i3507. 
88. Shamseer L, Moher D, Clarke M, Ghersi D, Liberati A, Petticrew M, et al. Preferred reporting items for systematic review and meta-analysis protocols (PRISMA-P) 2015: elaboration and explanation. BMJ. 2015;350:g7647. doi:10.1136/bmj.g7647.

89. Higgins JPT, Thomas, J., Chandler, J., Cumpston M, Li T, Page MJ, Welch VA(e). Cochrane Handbook for Systematic Reviews of Interventions version 6.0 (updated July 2019). 2019. www.training.cochrane.org/handbook.

90. Guyatt GH, Oxman AD, AkI EA, Kunz R, Vist G, Brozek J, et al. GRADE guidelines: 1. Introduction-GRADE evidence profiles and summary of findings tables. J Clin Epidemiol. 2011;64:383-94. doi:10.1016/j.jclinepi.2010.04.026.

91. Higgins JPT, Lasserson T, Chandler J, Tovey D, Thomas J, Flemyng E, Churchill R. Methodological Expectations of Cochrane Intervention Reviews. https://community.cochrane.org/mecir-manual.

92. Negrini S, Arienti C, Kiekens C. Cochrane Rehabilitation and the future of systematic reviews in developmental rehabilitation. Dev Med Child Neurol. 2019;61:1241. doi:10.1111/dmcn.14337.

93. Stillwell SB, Fineout-Overholt E, Melnyk BM, Williamson KM. Evidence-based practice, step by step: asking the clinical question: a key step in evidencebased practice. Am J Nurs. 2010;110:58-61. doi:10.1097/01.NAJ.0000368959.11129.79.

94. Colquhoun HL, Jesus TS, O'Brien KK, Tricco AC, Chui A, Zarin W, et al. Scoping Review on Rehabilitation Scoping Reviews. Arch Phys Med Rehabil. 2020;101:1462-9. doi:10.1016/j.apmr.2020.03.015.

95. Moher D, Shamseer L, Clarke M, Ghersi D, Liberati A, Petticrew M, et al. Preferred reporting items for systematic review and meta-analysis protocols (PRISMA-P) 2015 statement. Syst Rev. 2015;4:1. doi:10.1186/2046-4053-4-1.

96. Eisenmeier D, Ostermann T, Vogel H, Fetz K. (under review) Protocol: Neurorehabilitation according to Padovan-Method(r) for preventing and treating development disorders: protocoll for a systematical review. Logopedics Phoniatrics Vocology.

97. Negrini S. Evidence in Rehabilitation Medicine: Between Facts and Prejudices. Am J Phys Med Rehabil. 2019;98:88-96. doi:10.1097/PHM.0000000000001033.

98. Schardt C, Adams MB, Owens T, Keitz S, Fontelo P. Utilization of the PICO framework to improve searching PubMed for clinical questions. BMC Med Inform Decis Mak. 2007;7:16. doi:10.1186/1472-6947-7-16.

99. Vogel D, Ostermann T, Vogel H, Fetz K. Update: Development of an expert-consensus-based treatment recommendation for the PADOVAN-METHOD $\AA$ in neurorehabilitation.: Posterpresentation. The Online Journal of Scientific Poster 2020. doi:10.13140/RG.2.2.28377.34408.

100. Boehm K, Raak C, Vollmar HC, Ostermann T. An overview of 45 published database resources for complementary and alternative medicine. Health Info Libr J. 2010;27:93-105. doi:10.1111/j.1471-1842.2010.00888.x.

101. Hopewell S, Clarke M, Lefebvre C, Scherer R. Handsearching versus electronic searching to identify reports of randomized trials. Cochrane Database Syst Rev. 2007:MR000001. doi:10.1002/14651858.MR000001.pub2.

102. National Insitutes of Health. Literature Search: Databases and Gray Literature. 2019. https://www.nihlibrary.nih.gov/services/systematic-reviewservice/literature-search-databases-and-gray-literature.

103. Shpilko I. Locating grey literature on communication disorders. Med Ref Serv Q. 2005;24:67-80. doi:10.1300/J115v24n03_06.

104. Sterne JAC, Hernán MA, Reeves BC, Savović J, Berkman ND, Viswanathan M, et al. ROBINS-I: a tool for assessing risk of bias in non-randomised studies of interventions. BMJ. 2016;355:i4919. doi:10.1136/bmj.i4919.

105. Sterne JAC, Higgins JPT, Elbers RG, Reeves, BC and the development group for ROBINS-. Risk Of Bias In Non-randomized Studies of Interventions (ROBINS-I): detailed guidance. 2016. http://www.riskofbias.info. Accessed 16 Oct 2019.

106. Riley DS, Barber MS, Kienle GS, Aronson JK, Schoen-Angerer T von, Tugwell P, et al. CARE guidelines for case reports: explanation and elaboration document. J Clin Epidemiol. 2017;89:218-35. doi:10.1016/j.jclinepi.2017.04.026.

107. Weingarten MA, Paul M, Leibovici L. Assessing ethics of trials in systematic reviews. BMJ. 2004;328:1013-4. doi:10.1136/bmj.328.7446.1013.

108. Guyatt GH, Oxman AD, Vist G, Kunz R, Brozek J, Alonso-Coello P, et al. GRADE guidelines: 4. Rating the quality of evidence-study limitations (risk of bias). J Clin Epidemiol. 2011;64:407-15. doi:10.1016/j.jclinepi.2010.07.017.

109. Sanderson S, Tatt ID, Higgins JPT. Tools for assessing quality and susceptibility to bias in observational studies in epidemiology: a systematic review and annotated bibliography. Int J Epidemiol. 2007;36:666-76. doi:10.1093/ije/dym018.

110. Sterne JAC, Savović J, Page MJ, Elbers RG, Blencowe NS, Boutron I, et al. RoB 2: a revised tool for assessing risk of bias in randomised trials. BMJ. 2019;366:14898. doi:10.1136/bmj.14898.

111. Popay J, Roberts H, Sowden A, Petticrew M, Arai L, Rodgers M, et al. Guidance on the conduct of narrative synthesis in systematic reviews: A product from the ESRC Methods Programme: Lancaster University; 2006.

112. Dwan K, Altman DG, Arnaiz JA, Bloom J, Chan A-W, Cronin E, et al. Systematic review of the empirical evidence of study publication bias and outcome reporting bias. PLoS ONE. 2008;3:e3081. doi:10.1371/journal.pone.0003081.

113. Guyatt GH, Oxman AD, Vist GE, Kunz R, Falck-Ytter Y, Alonso-Coello P, Schünemann HJ. GRADE: an emerging consensus on rating quality of evidence and strength of recommendations. BMJ. 2008;336:924-6. doi:10.1136/bmj.39489.470347.AD.

114. Schünemann HJ, Cuello C, AkI EA, Mustafa RA, Meerpohl JJ, Thayer K, et al. GRADE guidelines: 18. How ROBINS-I and other tools to assess risk of bias in nonrandomized studies should be used to rate the certainty of a body of evidence. J Clin Epidemiol. 2019;111:105-14. doi:10.1016/j.jclinepi.2018.01.012.

115. Schünemann HJ, Brożek J, Guyatt G, Oxman AD. GRADE Handbook. https://gdt.gradepro.org/app/handbook/handbook.html. Accessed 26 Aug 2020. 
116. World Medical Association. Ethics Unit. WMA DECLARATION OF HELSINKI - ETHICAL PRINCIPLES FOR MEDICAL RESEARCH INVOLVING HUMAN SUBJECTS. 2018. https://www.wma.net/policies-post/wma-declaration-of-helsinki-ethical-principles-for-medical-research-involving-human-subjects/.

117. Vergnes J-N, Marchal-Sixou C, Nabet C, Maret D, Hamel O. Ethics in systematic reviews. J Med Ethics. 2010;36:771-4. doi:10.1136/jme.2010.039941.

118. Padovan BAE. Wie wichtig ist die Kommunikation für die Plastizität des Nervensystems? Neurofunktionelle Reorganisation - Padovan-Methode.: Kongressbeitrag. In: Wege zur Kommunikation: Kongressband. I. Kongress der Diplomierten Logopädinnen für Österreich - September 1996. Wien; 1997. p. 37.

119. Padovan BAE. El método Padovan como sistema terapéutico para las alteraciones funcionales orales y paraorales. In: ; 2007.

120. Padovan BAE. Método Padovan-Reorganização Neurofuncional. Vila Velha: Above publicações. 2013.

121. Padovan BAE. Terapia Miofuncional Orofacial - Método Padovan (Reorganização Neurofuncional): Segundo Artigo. Guadeloupe; März 1996.

122. Clinique Evolution LaSalle. Methode Padovan. http://cliniqueevolution.ca/en/padovan-method. Accessed 27 Aug 2020.

123. Falcão de Almeida J, Torrieri Nigro A, Pereira dos Santos C, de Oliveira Martinez, Maria Lúcia, Ghelman R. A fenomenologia de Goethe aplicada ao método Padovan de reorganização neurofuncional: Goethe's phenomenology applied to the Padovan method of neurofunctional reorganization. Arte Médica Ampliada. 2017;37:95-9.

124. Feliu Bas T. El mètode Padovan de reorganització neurofuncional (rnf): Cap a una logopèdia integrativa. logopèdia Revista del Collegi de Logopedes de Catalunya. 2013;24:8-10.

125. Franzke R. Neurofunktionelle Reorganisation nach Padovan. In: Kesper G, Achenbach B, editors. Sensorische Integration und Lernen: Grundlagen, Diagnostik und Förderung. München: Reinhardt; 2002.

126. Gurfinkel V, Grotti AZ. Método Padovan da Reorganização Neurofuncional.

127. Júnior P. Com o método Padovan todo o sistema nervoso é estimulado Entrevista com lolanda Bezerra Costa. 2010.

128. Pereira dos Santos C, Torrieri Nigro A, Falcão de Almeida J, de Oliveira Martinez, Maria Lúcia, Ghelman R. O método Padovan de reorganização neurofuncional sob a ótica da fenomenologia da trimembração pela medicina antroposófica: The Padovan method of neurofunctional reorganization from the perspective of the threefold phenomenology of anthroposophic medicine. Arte Médica Ampliada. 2017;37:115-7.

129. Schönfeld A. Ist es möglich, ganzheitlich orientierte Therapiemethoden in ihrer gesamten Dimension diagnostisch zu erfassen, um diese im Rahmen der evidenzbasierten Medizin nach wissenschaftlichen Kriterien zu evaluieren?: Eine quantitative Datenanalyse am exemplarischen Beispiel der Neurofunktionellen Reorganisation (NFR®) nach Beatriz Padovan [Bachelor Thesis]. Hamburg: Hamburger Fernhochschule; 2013.

130. Grohnfeldt M. Beratung, Therapie und Rehabilitation. Stuttgart: Kohlhammer; 2003.

131. Treuenfels H von. Der Beitrag der Systemischen Kieferorthopädie für Schlaf und Gesundheit. Zeitschrift für Komplementärmedizin. 2014;06:23-9. doi:10.1055/s-0034-1386739.

132. Treuenfels H von. Die neue Biognathe Orthese und Padovan Übungen. GZM Praxis und Wissenschaft;7:65.

133. Frazão AP, Pereira LM, Silva, Maria das Graças Nascimento, Correira CMS, Silton, Alda Lúcia Afonso Ferreira. Estimulação Neurofuncional dos Cinco Sentidos com o Método Padovan [Thesis]. Juazeiro do Norte: Faculdade de Medicina Estácio de Juazeiro do Norte-CE; 2012.

134. Cadoux L. La Rehabilitation Neuro-Functionelle Chez Les Enfants Porteurs De Trisomie 21: Thèse Pour Le Diplôme De Docteur En Chirurgie Dentaire [Thesis]. Toulouse: Université Toulouse III; 2017.

135. Levrini L, Lorusso P, Caprioglio A, Magnani A, Diaféria G, Bittencourt L, Bommarito S. Model of oronasal rehabilitation in children with obstructive sleep apnea syndrome undergoing rapid maxillary expansion: Research review. Sleep Sci. 2014;7:225-33. doi:10.1016/j.slsci.2014.11.002.

136. Hahn V. Oral stereognosis and orofacial dyskinesia: A clinical investigation. Sprache · Stimme · Gehör. 1997;21:185-91.

137. Klein S. Orofaciale Dysfunktion - ein interdisziplinäres Aufgabenfeld mit spezieller Berücksichtigung der "Integrierten Myo-neurotherpie" von Beatriz Alves de Edmir Padovan: Diplomarbeit im Fach Heilpädagogik vorgelegt für die Diplomprüfung [Diplomarbeit]. Köln: Universität zu Köln; 1995.

138. Weinrich M, Zehner H. Phonetische und phonologische Störungen bei Kindern: Aussprachetherapie in Bewegung. 5th ed. Berlin, Heidelberg, s.I.: Springer Berlin Heidelberg; 2017.

139. Machado OD-V, Grande S, Menezes E, Fróes do Nascimento L, Jungen R. Projekt zur Krisensituation der Spitalüberlastungen in Brasilien - Einführung der Anthroposophischen Medizin im öffentlichen Staats - spital Andaraí, Rio de Janeiro, Brasilien. Der Merkurstab. 69;2016:60-1.

140. Rocher S. Reeducation D'Une Langue Basse Parla Methode Padovan [Travail de Fin d'Etudes]. Villle de Liège: Ecole Supérierue de Logopedie; 2011.

141. Ullrich D, Ullrich K, Marten M. Schulentwicklung bei Kindern mit schweren Sprachentwicklungsstörungen Nachbeobachtung bis zu 15 Jahren nach Entlassung aus Sprachheilkindergärten. Laryngorhinootologie. 2009;88:647-52. doi:10.1055/s-0029-1220945.

142. Kesper G, Achenbach B, editors. Sensorische Integration und Lernen: Grundlagen, Diagnostik und Förderung. München: Reinhardt; 2002.

143. Suchodoletz W von. Sprech- und Sprachentwicklungsstörungen. In: Petermann F, editor. Lehrbuch der Klinischen Kinderpsychologie. 7th ed. Göttingen: Hogrefe; 2013. p. 229-243.

144. Błeszyński JJ. Wczesna interwencja-różne podejścia, ujęcia, definicje. Różne nie znaczy sprzeczne.

145. Bigenzahn W, Fischman L. Orofaziale Dysfunktionen im Kindesalter: Grundlagen, Klinik, Ätiologie, Diagnostik und Therapie. 2nd ed. Stuttgart: Thieme; 2003.

146. Brzozowska-Misiewicz I. Metoda neurofunkcjonalnej reorganizacji wg Padovan. In: ; 2014. p. 49-54.

147. Meilinger M. Untersuchung ausgewählter Aspekte myofunktioneller Störungen im Vorschulalter. München: Utz Wiss; 1999.

148. Sadowska J, Dragun G, Gutowska A, Szczepaniak R. Znaczenie prawidłowej postawy ciała podczas ćwiczeń logopedycznych. In: ; 2016. p. 25-70.

Page 22/66 
149. Suchodoletz W von. Lese-Rechtschreib-Störung (LRS) - Fragen und Antworten: Eine Orientierungshilfe für Betroffene, Eltern und Lehrer. 1st ed. Stuttgart: Kohlhammer; 2007.

150. Suchodoletz W von. Alternative Therapiemethoden. In: Suchodoletz W von, editor. Therapie von Entwicklungsstörungen: Was wirkt wirklich? Göttingen, Bern, Wien, Paris, Oxford, Prag, Toronto, Cambridge, Mass., Amsterdam, Kopenhagen, Stockholm: Hogrefe; 2010. p. 231-254.

151. Suchodoletz W von. Sprachentwicklungsstörungen. In: Hoffmann GF, Lentze MJ, Spranger J, Zepp F, editors. Pädiatrie. Berlin, Heidelberg: Springer Berlin Heidelberg; 2015. p. 1-4. doi:10.1007/978-3-642-54671-6_282-1.

152. Doering W, Doering W, Dose G, Stadelmann M. Sinn und Sinne im Dialog. Der Kongreß zur Wahrnehmung. 2. bis 4. März 1995, Marburg. Dortmund: Borgmann; 1996.

153. Kannegiesser-Leitner C, Warnke R. Hemoencephalography: A Practical Approach to Neurofeedback Training. In: International Society for Neurofeedback and Research, editor. Neuroconnections: A joint newsletter from the ISNR \& the AAPB Neurofeedback Division. San Rafael, CA: ISNR. p. 23-29.

154. Marjorie S. La Méthode Padovan pour votre enfant autiste. 2014. http://site.prosinapse.com.br/wpcontent/uploads/prosinapse_site/2016/12/laméthodepourvotreenfantautiste.pdf.

155. Montpetit L. La réorganisation neuro-fonctionnelle. Le Lundi.

156. Padovan S. L'efficacité de la Méthode Padovan de réorganisation neuro-fonctionnelle. inmare. 2007.

157. Vaineau A-L. La méthode Padovan, c'est quoi ? 2016. http://site.prosinapse.com.br/wpcontent/uploads/prosinapse_site/2016/12/laméthodepadovan.pdf.

158. Bernard S, Colomb M, Pallas E, Richel M. Myasthénie et réorganisation neurofonctionnelle méthode Padovan: Etude de cas. Toulouse: Université Toulouse III Paul Sabatier.

159. Chamussy L. Ostéopathie et méthode Padovan, vers une complémentarité chez les enfants en difficulté [Memoire]. Lyon: ISOstéo; 17.07.2011.

160. Jausas P. Prise en charge orthophonique de la deglutition atypique par la Methode Padovan®. Quelles critiques?: en vue de l'obtention du certificat de capacité d'orthophonie [Thesis]. Poitiers: Université de Poitiers Faculté de médecine et de pharmacie École d'orthophonie; 2013.

161. Le Pottier M. Troubles envahissants du développement et réorganisation neurofonctionnelle méthode Padovan: quels apports pour la prise en charge orthophonique?: étude longitudinale de la prise en charge orthophonique de sujets TED dans le cadre de la méthode Padovan: Etude longitudinale de la prise en charge orthophonique de sujets TED dans le cadre de la méthode Padovan. [Mémoire présenté pour l'obtention du Certificat de Capacité d'Orthophonie]. Lille: Université de Lille II; 2010.

162. Loyer N. Influences posturales et neurophysiologiques sur les fonctions oro-faciales: étude de prises en charge en réorganisation neuro-fonctionnelle dans le cadre de pathologies lourdes. Strasbourg: Université Louis Pasteur; 2011.

163. Morral Subirà À, Pallàs Troyano F. Padovan desde una óptica relacional: una experiencia con niños pequeños con TEA: Padovan Method From a Relational Perspective: An Experience With Little Children With ASD. Revista Iberoamericana de Psicomotricidad y Técnicas Corporales. 2017;42:163-75.

164. Froitzheim R, Richter J. Neurofunktionelle Reorganisation nach Beatriz A.E. Padovan anhand eines Fallbeispiels: Beiheft zur DVD [Bachelor Thesis]. Amsterdam: Hoogeschool van Amsterdam; 2010.

165. Großweischede K. Die Bedeutung der Padovan-Methode in der Sprachheilpädagogik: Theoretische Grundlagen, Konzeptdiskussion, Praxisrelevanz mit Falldarstellung [Diplomarbeit]. Köln: Universität zu Köln; 2000.

166. Kunert N. Die "Neurofunktionelle Reorganisation" nach Padovan. Forum Logopädie. 2003;17:20-5.

167. Pereira LM, Vileicar DC, Uchôa MMA. Neuro-rehabilitation with the Padovan method® in newborn babies with fetal alcoholic syndrome: report of 2 cases: report of 2 cases. J Health Biol Sci. 2018;6:214. doi:10.12662/2317-3076jhbs.v6i2.1769.p214-216.2018.

168. Moher D, Liberati A, Tetzlaff J, Altman DG. Preferred reporting items for systematic reviews and meta-analyses: the PRISMA statement. BMJ. 2009;339:b2535. doi:10.1136/bmj.b2535.

169. Frank G, Grziwotz P. Lautprüfbogen: Sprachheilzentrum Ravensburg; 1985.

170. Bellingen V. Gesamtheitliche Behandlung myofunktioneller Störungen. Wirksamkeitsstudie zur Padovan-Methode®. Kieferorthopädie. 2016;30:389-96.

171. Manacero S, Nunes ML. Evaluation of motor performance of preterm newborns during the first months of life using the Alberta Infant Motor Scale (AIMS). J Pediatr (Rio J). 2008;84:53-9. doi:10.2223/JPED.1741.

172. Fisher RA. Statistical methods for research workers. Statistical methods for research workers. 1934.

173. Zimmer R, Volkamer M. Motoriktest für vier-bis sechsjährige Kinder: Mot 4-6; Manual: Beltz-Test; 1984.

174. Grimm H, Aktas M, Frevert S. SETK 3-5: Sprachentwicklungstest für drei-bis fünfjährige Kinder [Language development test for three to five year old children; German version]. Göttingen: Hogrefe. 2001.

175. IOPI Medical LLC. lowa Oral Performance Instrument: users manual. 2008. http://www.iopimedical.com. Accessed 22 Aug 2020.

176. Büttner F. Die quantitative Untersuchung des motorischen Systems (Q-Motor) bei Kindern mit orofazialer Dysfunktion. Berlin: FU Berlin; 2018.

177. Kittel AM, Förster AT. Übungsblocks Myofunktionelle Therapie: Ruhelageübungen, Körperübungen, Zungenübungen, Lippenübungen, Ansaugübungen, Schluckübungen, Intervallbehandlung. 8th ed. Idstein: Schulz-Kirchner; 2010.

178. Bruininks RH, Bruininks BD. BOT2: Bruininks-Oseretsky test of motor proficiency: AGS Publishing; 2005.

179. Arthasana S. Auswirkungen einer chirurgischen Intervention auf die Polysomnographie bei Säuglingen und Kleinkindern mit obstruktivem Schlafapnoesyndrom. 2016.

180. Giel B, Tillmanns-Karus M. Kölner Diagnostikbogen für Myofunktionelle Störungen. Dortmund: Verlag Modernes Lernen; 2004.

181. Finkbeiner G, Metzner, Pfeiffer, Schönfeld A. Befund- und Verlaufsprotokoll zur Neurofunktionellen Reorganisation IPVP: unpublished 2012.

Page 23/66 
182. Shiel A, Horn SA, Wilson BA, Watson MJ, Campbell MJ, McLellan DL. The Wessex Head Injury Matrix (WHIM) main scale: a preliminary report on a scale to assess and monitor patient recovery after severe head injury. Clin Rehabil. 2000;14:408-16. doi:10.1191/0269215500cr326oa.

183. Giacino JT, Kalmar K, Whyte J. The JFK Coma Recovery Scale-Revised: measurement characteristics and diagnostic utility. Arch Phys Med Rehabil. 2004;85:2020-9. doi:10.1016/j.apmr.2004.02.033.

184. Beaumont JG, Marjoribanks J, Flury S, Lintern T. Putney auditory comprehension screening test (PACST). Bury St. Edmunds, UK: Thames Valley Test Company. 2002.

185. Hall KM, Hamilton BB, Gordon WA, Zasler ND. Characteristics and comparisons of functional assessment indices: disability rating scale, functional independence measure, and functional assessment measure. The Journal of Head Trauma Rehabilitation. 1993.

186. Granger CV, Hamilton BB, Keith RA, Zielezny M, Sherwin FS. Advances in functional assessment for medical rehabilitation. Topics in geriatric rehabilitation. 1986;1:59-74.

187. Codoni S, Spirgi-Gantert I, Jackowski J von. Funktionsorientierte Logopädie: Der Einfluss von Haltung und Bewegung auf Schlucken, Sprechen und Sprache: Springer-Verlag; 2018.

188. Balshem H, Helfand M, Schünemann HJ, Oxman AD, Kunz R, Brozek J, et al. GRADE guidelines: 3. Rating the quality of evidence. J Clin Epidemiol. 2011;64:401-6. doi:10.1016/j.jclinepi.2010.07.015.

189. Wilcoxon F. Individual Comparisons by Ranking Methods. In: Kotz S, Johnson NL, editors. Breakthroughs in Statistics. New York, NY: Springer New York; 1992. p. 196-202. doi:10.1007/978-1-4612-4380-9_16.

190. Guyatt GH, Ebrahim S, Alonso-Coello P, Johnston BC, Mathioudakis AG, Briel M, et al. GRADE guidelines 17: assessing the risk of bias associated with missing participant outcome data in a body of evidence. J Clin Epidemiol. 2017;87:14-22. doi:10.1016/j.jclinepi.2017.05.005.

191. Guyatt GH, Oxman AD, Kunz R, Woodcock J, Brozek J, Helfand M, et al. GRADE guidelines: 7. Rating the quality of evidence-inconsistency. J Clin Epidemiol. 2011;64:1294-302. doi:10.1016/j.jclinepi.2011.03.017.

192. Guyatt GH, Oxman AD, Kunz R, Woodcock J, Brozek J, Helfand M, et al. GRADE guidelines: 8. Rating the quality of evidence-indirectness. J Clin Epidemiol. 2011;64:1303-10. doi:10.1016/j.jclinepi.2011.04.014.

193. Andrews J, Guyatt G, Oxman AD, Alderson P, Dahm P, Falck-Ytter Y, et al. GRADE guidelines: 14. Going from evidence to recommendations: the significance and presentation of recommendations. J Clin Epidemiol. 2013;66:719-25. doi:10.1016/j.jclinepi.2012.03.013.

194. Alves JB, Gabani FL, Ferrari RAP, Tacla MTGM, Linck Júnior A. SEPSE NEONATAL: MORTALIDADE EM MUNICÍPIO DO SUL DO BRASIL, 2000 A 2013. Rev. paul. pediatr. 2018;36:132-40. doi:10.1590/1984-0462/;2018;36;2;00001.

195. Page P, Hoogenboom B, Voight M. IMPROVING THE REPORTING OF THERAPEUTIC EXERCISE INTERVENTIONS IN REHABILITATION RESEARCH. Int J Sports Phys Ther. 2017;12:297-304.

196. Bayley N. Bayley Scales of Infant and Toddler Development: Administration Manual. 3rd ed. United States of America: Psychorp; 2006.

197. McCarthy D. McCarthy scales of children's abilities (MSCA): Psychological Corporation; 1972.

198. Raven JC. Raven's Coloured Progressive matrices Manual. San Antonio: TX: Harcourt Assessment; 1998.

199. Karakosta P, Margetaki K, Fthenou E, Kampouri M, Kyriklaki A, Koutra K, et al. Cord Leptin is Associated with Neuropsychomotor Development in Childhood. Obesity (Silver Spring). 2019;27:1693-702. doi:10.1002/oby.22571.

200. Moher D, Schulz KF, Altman D. The CONSORT statement: revised recommendations for improving the quality of reports of parallel-group randomized trials. JAMA. 2001;285:1987-91. doi:10.1001/jama.285.15.1987.

201. Dimairo M, Pallmann P, Wason J, Todd S, Jaki T, Julious SA, et al. The Adaptive designs CONSORT Extension (ACE) statement: a checklist with explanation and elaboration guideline for reporting randomised trials that use an adaptive design. BMJ. 2020;369:m115. doi:10.1136/bmj.m115.

202. Shamseer L, Sampson M, Bukutu C, Schmid CH, Nikles J, Tate R, et al. CONSORT extension for reporting N-of-1 trials (CENT) 2015: explanation and elaboration. J Clin Epidemiol. 2016;76:18-46. doi:10.1016/j.jclinepi.2015.05.018.

203. Boutron I, Altman DG, Moher D, Schulz KF, Ravaud P. CONSORT Statement for Randomized Trials of Nonpharmacologic Treatments: A 2017 Update and a CONSORT Extension for Nonpharmacologic Trial Abstracts. Ann Intern Med. 2017;167:40-7. doi:10.7326/M17-0046.

204. Gagnier JJ, Kienle G, Altman DG, Moher D, Sox H, Riley D. The CARE Guidelines: Consensus-based Clinical Case Reporting Guideline Development. Glob Adv Health Med. 2013;2:38-43. doi:10.7453/gahmj.2013.008.

205. Elm E von, Altman DG, Egger M, Pocock SJ, Gøtzsche PC, Vandenbroucke JP. The Strengthening the Reporting of Observational Studies in Epidemiology (STROBE) statement: guidelines for reporting observational studies. J Clin Epidemiol. 2008;61:344-9. doi:10.1016/j.jclinepi.2007.11.008.

206. Eisenmeier D, Ostermann T, Vogel H, Fetz K. Development of an expert consensus based treatment recommendation for the PADOVAN METHOD $\AA$ in neurorehabilitation: Conference Abstract. Neurologie \& Rehabilitation. 2019;25:64-5. doi:10.14624/NR1912001.

207. Jurek-Schick A. Request: congress band 1997 of logopaedic congress vienna 04.08.2020.

\section{Appendix}

\section{Appendix Large Tables}

Table 16. Clinical recommendations 


\begin{tabular}{|c|c|c|}
\hline \multicolumn{2}{|c|}{ Condition / Outcome } & PICOT Recommendation \\
\hline I & Microcephalia & $\begin{array}{l}\text { In patients with microcephalia an application of therapy according to the Padovan-Method® by trained therapists might be } \\
\text { considered by clinicians (weak recommendation) and a relief of some symptoms might be possible within a time span } \\
\text { from } 2 \text { to } 12 \text { months. Further research and investigation are highly recommended in order to reduce the uncertainty of } \\
\text { effect. }\end{array}$ \\
\hline II & Down-Syndrome & $\begin{array}{l}\text { In patients with down-syndrome disorders an application of therapy according to the Padovan-Method@ by trained } \\
\text { therapists might be considered by clinicians (weak recommendation) and a relief of some symptoms might be possible } \\
\text { within a time span from a few weeks to } 6 \text { months. Further research and investigation are highly recommended in order to } \\
\text { reduce the uncertainty of effect. }\end{array}$ \\
\hline III & $\begin{array}{l}\text { Neurological } \\
\text { disorders }\end{array}$ & $\begin{array}{l}\text { In patients with neurological disorders an application of therapy according to the Padovan-Method® by trained therapists } \\
\text { might be considered by clinicians (weak recommendation) and a relief of some symptoms might be possible within a time } \\
\text { span from a few days to } 24 \text { months. Further research and investigation are highly recommended in order to reduce the } \\
\text { uncertainty of effect. }\end{array}$ \\
\hline IV & $\begin{array}{l}\text { Myo-functional } \\
\text { disorders }\end{array}$ & See section $(C)$ in this table. \\
\hline$A$ & Motoric dysfunction & $\begin{array}{l}\text { In patients with motoric dysfunction an application of therapy according to the Padovan-Method } \circledast \text { by trained therapists } \\
\text { might be considered by clinicians (weak recommendation) and a relief of some symptoms might be possible within a time } \\
\text { span from a few days to } 24 \text { months. Further research and investigation are highly recommended in order to reduce the } \\
\text { uncertainty of effect. }\end{array}$ \\
\hline $\mathrm{B}$ & $\begin{array}{l}\text { Neuropsychomotoric } \\
\text { development } \\
\text { disorder }\end{array}$ & $\begin{array}{l}\text { In patients with neuropsychomotoric development disorder an application of therapy according to the Padovan-Method@ } \\
\text { by trained therapists might be considered by clinicians (weak recommendation) and a relief of some symptoms might be } \\
\text { possible within a time span from a few days to } 24 \text { months. Further research and investigation are highly recommended in } \\
\text { order to reduce the uncertainty of effect. }\end{array}$ \\
\hline $\begin{array}{l}\mathrm{C} \\
\text { (IV) }\end{array}$ & $\begin{array}{l}\text { Orofacial- or } \\
\text { myo-functional } \\
\text { disorder }\end{array}$ & $\begin{array}{l}\text { In patients with orofacial or myo-functional disorders an application of therapy according to the Padovan-Method@ by } \\
\text { trained therapists might be considered by clinicians (weak recommendation) and a relief of some symptoms might be } \\
\text { possible within a time span from a few days to } 24 \text { months. Further research and investigation are highly recommended in } \\
\text { order to reduce the uncertainty of effect. }\end{array}$ \\
\hline $\mathrm{D}$ & $\begin{array}{l}\text { Speech or } \\
\text { articulation } \\
\text { difficulties }\end{array}$ & $\begin{array}{l}\text { In patients with speech or articulation difficulties an application of therapy according to the Padovan-Method® by trained } \\
\text { therapists might be considered by clinicians (weak recommendation) and a relief of some symptoms might be possible } \\
\text { within a time span from a few days to } 24 \text { months. Further research and investigation are highly recommended in order to } \\
\text { reduce the uncertainty of effect. }\end{array}$ \\
\hline
\end{tabular}

Notes. For all recommendations further research is highly recommended and has a large potential in order to reduce the uncertainty.

Appendix A: Definitions

Table A1. Definition of overall judgement about risk of bias

\begin{tabular}{|c|c|c|}
\hline Level & Description & Criterion \\
\hline $\begin{array}{l}\text { Low risk of } \\
\text { bias }\end{array}$ & $\begin{array}{l}\text { The study is comparable to a well-performed randomized } \\
\text { trial. }\end{array}$ & The study is judged to be at low risk of bias for all domains. \\
\hline $\begin{array}{l}\text { Moderate } \\
\text { risk of bias }\end{array}$ & $\begin{array}{l}\text { The study provides sound evidence for a non-randomized } \\
\text { study but cannot be considered comparable to a well- } \\
\text { performed randomized trial. }\end{array}$ & The study is judged to be at low or moderate risk of bias for all domains \\
\hline $\begin{array}{l}\text { Serious risk } \\
\text { of bias }\end{array}$ & The study has some important problems. & $\begin{array}{l}\text { The study is judged to be at serious risk of bias in at least one domain, but } \\
\text { not at critical risk of bias in any domain. }\end{array}$ \\
\hline $\begin{array}{l}\text { Critical risk } \\
\text { of bias }\end{array}$ & $\begin{array}{l}\text { The study is too problematic to provide any useful } \\
\text { evidence and should not be included in any synthesis. }\end{array}$ & The study is judged to be at critical risk of bias in at least one domain. \\
\hline $\begin{array}{l}\text { No } \\
\text { Information }\end{array}$ & $\begin{array}{l}\text { No information on which to base a judgement about risk of } \\
\text { bias. }\end{array}$ & $\begin{array}{l}\text { There is no clear indication that the study is at serious or critical risk of bias } \\
\text { and there is a lack of information in one or more key domains of bias (a } \\
\text { judgement is required for this). }\end{array}$ \\
\hline
\end{tabular}

Notes. Source: Supplement of Sterne JAC, Hernán MA, Reeves BC, et al. [104]

Table A2. Definition of quality according to GRADE

\begin{tabular}{|ll|}
\hline Term & Description \\
\hline high & further research is very unlikely to change our confidence in the estimate of effect \\
\hline moderate & further research is likely to have an important impact on our confidence in the estimate of effect and may change the estimate \\
\hline low & further research is very likely to have an important impact on our confidence in the estimate of effect and is likely to change the estimate \\
\hline very low & very uncertain about the estimate of effect \\
\hline
\end{tabular}

Notes. Source: [113]

Table A3. Reasons for grading down

Page 25/66 


\begin{tabular}{|ll|}
\hline Reason & Decrease \\
\hline Study limitation for risk of bias & Serious (-1) or very serious (-2) \\
\hline Inconsistency between study results & \\
\hline Uncertainty about directness & \\
\hline Imprecision of the result & \\
\hline
\end{tabular}

Notes. Source: [90]

Table A4. Guide for ethical assessment of trials in systematic reviews

\begin{tabular}{|c|c|}
\hline Issue & Description \\
\hline \multirow[t]{9}{*}{ Goal related considerations } & Is there a clear declaration on financial support in all trials? \\
\hline & Is there a statement that relates to potential conflicts of interest in all trials? \\
\hline & . Justification- \\
\hline & Could the results have been obtained by laboratory or animal experiments? \\
\hline & Were any of the trials superfluous? \\
\hline & Was the size of the study sufficient to achieve adequate statistical power? \\
\hline & . $\quad$ Publication bias- \\
\hline & How many of the identified trials remained unpublished? \\
\hline & Is bias detectable by funnel plot analysis? ${ }^{a}$ \\
\hline Duty related considerations & Were the comparators appropriate? If a placebo was used, was it justified? \\
\hline \multirow[t]{7}{*}{ Rights related considerations } & S $\quad$ Safety- \\
\hline & Was the risk for participants appropriate to the importance of the research? \\
\hline & Was appropriate follow up care assured? \\
\hline & Was informed consent obtained? \\
\hline & When participants had reduced competence, were appropriate measures taken to protect their best interests? \\
\hline & Were adequate steps taken to prevent unauthorised access to personal \\
\hline & and clinical data? \\
\hline Global considerations & Was the study approved by a research ethics committee? \\
\hline
\end{tabular}

Notes. Source: Weingarten et al. 2004 [107], p. 1013.

${ }^{\mathrm{a}}$ Not applied.

\section{Appendix B: Databases and excluded sources}

Table B1. Databases searched, number of results 


\begin{tabular}{|c|c|}
\hline Database $^{a}$ & Search results \\
\hline Pubmed & $12 / 1^{b}$ \\
\hline Cochrane Library & $0 / 0^{b}$ \\
\hline Embase & 17 \\
\hline Cambase & 1 \\
\hline Epistemonikos & 0 \\
\hline Uptodate & 0 \\
\hline CINAHL & 2 \\
\hline Psyndex & 5 \\
\hline TOC Premier & 27 \\
\hline E-Journals Database & 34 \\
\hline Psyclnfo & $1 / 0^{\mathrm{b}}$ \\
\hline PsycArticles & 0 \\
\hline PsycBooks & 0 \\
\hline AWMF & 9 \\
\hline BIREME & 15 \\
\hline SciELO & 1 \\
\hline SpeechBITE & 6 \\
\hline Otseeker & 0 \\
\hline Pedro & 0 \\
\hline DARE and NHS EED & 1 \\
\hline Sagepub & 0 \\
\hline Scopus & 95 \\
\hline Anthromedics & 1 \\
\hline PROSPERO & 1 \\
\hline NTIS - central resource for government-funded scientific, technical, engineering, and business related information. & 0 \\
\hline AHRQ - agency for healthcare research and quality & 0 \\
\hline Gray Source Index & 0 \\
\hline OpenDOAR - directory of academic repositories & 0 \\
\hline International Clinical Trials Registry Platform - from the World Health Organization & 0 \\
\hline Australian New Zealand Clinical Trials Registry & 0 \\
\hline Brazilian Clinical Trials Registry & 1 \\
\hline Chinese Clinical Trial Registry- & 0 \\
\hline ClinicalTrials.gov - U.S. and international federally and privately supported clinical trials registry and results database & 0 \\
\hline Clinical Trials Registry - India & 0 \\
\hline EU clinical Trials Register & 1 \\
\hline Pan African Clinical Trials Registry & 0 \\
\hline Open Gray & 3 \\
\hline ISRCTNregistry & 0 \\
\hline GoogleScholar & 230 \\
\hline Hand search & 69 \\
\hline
\end{tabular}


Notes. ${ }^{\text {aD }}$ atabases were searched from the date of inception to the search date. ${ }^{\mathrm{b}}$ Re-run of the search $27^{\text {th }}$ August 2020.

Table B2. References excluded, reason

Page 28/66 
Abad Bender, N. (2017). Myofunktionelle Therapie in der Padovan-Methode ${ }^{\circledR}$ : Neurofunktinelle Reorganisation. Sprachtherapie Aktuell: Forschung - Wissen - Transfer: Schwerpunkthtema: Intensive Sprachtherapie (4). (09), 1-18. https://doi.org/10.14620/stadbsl171109
Items containir general inform about the Padc Method®

Discussion par recommending Padovan-Meth

Abad Bender, N. (2019). Die Padovan-Methode® : Neurofunktionelle Reorganisation in der Ergotherapie. Praxis Ergotherapie, 32(3), 142149.

Ars, C., \& Chaudoye-Kimmes, A. (2013). Apports et limites de la méthode Padovan dans la prise en charge des troubles d'oralité des jeunes enfants porteurs de trisomie 21: étude de cas cliniques de trois enfants de 1 à 4 ans. Certificat de Capacité d'Orthophonie: Universitätsintern. Retrieved from http://pepite.univ-lille2.fr/notice/view/UDSL2-workflow-4435

Bäuml, D. M. (2007). Síndrom de Down: A Intervenção Humana e Tecnológica: Linguagem - Leitura - Excrita. Tese de Doutorado. Florianópolis.

Bernard, S., Colomb, M., Pallas, E., \& Richel, M. Myasthénie et réorganisation neurofonctionnelle méthode Padovan: Etude de cas. Université Toulouse III Paul Sabatier, Toulouse.

Bigenzahn, W., \& Fischman, L. (2003). Orofaziale Dysfunktionen im Kindesalter: Grundlagen, Klinik, Ätiologie, Diagnostik und Therapie (2., überarb. und erw. Aufl.). Forum Logopädie. Stuttgart: Thieme.

Błeszyński, J. J. Wczesna interwencja-różne podejścia, ujęcia, definicje. Różne nie znaczy sprzeczne.

Brzozowska-Misiewicz, I. (2014). Metoda neurofunkcjonalnej reorganizacji wg Padovan. In Forum Logopedy.

Bucheli-Zemp, I. (2008). Ein "merkwürdiger" Therapieansatz: Ganzheitliche Entwicklungstherapie mit Funktioneller Entspannung nach Marianne Fuchs und Neurofunktioneller Reorganisation nach Padovan. L.O.G.O.S. Interdisziplinär, 16(2), 120-126. Retrieved from http://31.12.57.70/libero/WebOpac.cls?

VERSION=2\&ACTION=DISPLAY\&RSN=10033861\&DATA=HSW\&TOKEN=FeUqgSMKr9464\&Z=1\&SET=1

Cadoux, L. La Rehabilitation Neuro-Funkctionelle Chez Les Enfants Porteurs De Trisomie 21 (Manuscript). Université Toulouse III, Toulouse.

Candel, I., \& Bonilla, C. (2016). El método Padovan...ंes recomendable?: opinión de los expertos en Atención Temprana de Down España: Profesionales del ámbito de la Atención Temprana dan su opinión sobre este controvertido método de estimulación para niños con síndrome de Down. Retrieved from https://www.sindromedown.net/noticia/articulo-el-metodo-padovan-es-recomendable/

Study - exclud $\epsilon$ to language res

Discussion par recommending Padovan-Meth

Study - exclud $\epsilon$ to language res

Mentioning $\mathrm{Pa}$ Method $\circledast$

Discussion par recommending Padovan-Meth

Mentioning $\mathrm{Pa}$ Method $\circledast$

Items containir general inform about the Padc Method $\AA$

Discussion par recommending Padovan-Meth

Unspecified information ab method

Chamussy, L. (2011). Ostéopathie et méthode Padovan, vers une complémentarité chez les enfants en difficulté(Memoire). ISOstéo, Lyon.

Clinique Evolution LaSalle. Methode Padovan: How to reorganize your neurofunctions. Retrieved from http://cliniqueevolution.ca/en/padovan-method

Items containir general inform: about the Padc Method ${ }^{\circ}$

Costa do Nascimento, Tereza Á, Pereira, L. M., Soares Dias, P., Ferreira Lopes, S. M., \& das Neves Menezes, Maria Isabelle (2016). Efeitos Do Método Padovan No Tratamento De Crianças Com Microcefalia. online available abstact of study results. Retrieved from

Study

anouncement/ http://portal.estacio.br/media/5460/efeitos-do-método-padovan-no-tratamento-de-crianças-com-microcefalia.pdf

- no fulltext av

Costa, \& lolanda Bezerra (2017). O que é a Disfagia. Retrieved from http://site.prosinapse.com.br/wpcontent/uploads/prosinapse_site/2017/09/oqueéadisfagia.pdf

Discussion par recommending Padovan-Meth

Dhamapurkar, S. K., Rose, A., Florschutz, G., \& Wilson, B. A. (2016). The natural history of continuing improvement in an individual after a long period of impaired consciousness: The story of I.J. Brain Injury, 30(2), 230-236. https://doi.org/10.3109/02699052.2015.1094132

Discussion par recommending Padovan-Meth

Doering, W. [Waltraud], Doering, W. [Winfried], Dose, G., \& Stadelmann, M. (1996). Sinn und Sinne im Dialog. Der Kongreß zur Wahrnehmung. 2. bis 4. März 1995, Marburg. Dortmund: Borgmann.

Unspecified information $a b$ method

Falcão de Almeida, J., Torrieri Nigro, A., Pereira dos Santos, C., de Oliveira Martinez, Maria Lúcia, \& Ghelman, R. (2017). A fenomenologia de Goethe aplicada ao método Padovan de reorganização neurofuncional: Goethe's phenomenology applied to the Padovan method of neurofunctional reorganization. Arte Médica Ampliada, 37(3), 95-99. Retrieved from http://abmanacional.com.br/wpcontent/uploads/2019/01/37-3-Me\%CC\%81todo-Padovan.pdf

Feliu Bas, T. (2013). El mètode Padovan de reorganització neurofuncional (rnf): Cap a una logopèdia integrativa. Logopèdia Revista Del Collegi De Logopedes De Catalunya, 24, 8-10. Retrieved from https://www.clc.cat/pdf/module_26/10001978/Logopedia24 quqRSRETW2qbKKFw9Ubq_ca.pdf

Items containir general inform about the Padc Method ${ }^{\circledR}$

Items containir general inform about the Padc Method $\circledast$

Finkbeiner, G. (2008). Myofunktionelle Störungen Vergleich klassischer Ansichten mit der Neurofunktionellen Reorganisation nach Items containir general inform about the Padc Method $\circledast$ 
Franzke, R. (2002). Neurofunktionelle Reorganisation nach Padovan. In G. Kesper \& B. Achenbach (Eds.), Heilpädagogik. Sensorische Integration und Lernen: Grundlagen, Diagnostik und Förderung. München: Reinhardt.
Items containir general inform: about the Padc Method®

Discussion par recommending Padovan-Meth

Frazão, A. P., Pereira, L. M., Silva, Maria das Graças Nascimento, Correira, C. M. S., \& Silton, Alda Lúcia Afonso Ferreira (2012). Estimulação Neurofuncional dos Cinco Sentidos com o Método Padovan. Thesis (Bacharel em Medicina).

Gauthier, C., Boudreault, N. L., Gilbert, C., Perras, H., Désilets, J., Filiatrault, A., \& Jasmin, E. (2016). La méthode Padovan ${ }^{\circledR}$ de réorganisation neurofonctionnelle auprès des enfants présentant un trouble de l'acquisition de la coordination : une étude exploratoire mixte. Revue Francophone de Recherche en Ergothérapie. Advance online publication. https://doi.org/10.13096/rfre.v2n1.24

Grohnfeldt, M. [M.] (Ed.) (2007). Lexikon der Sprachtherapie: Kohlhammer Verlag.

Study - exclud $\epsilon$ to language res

Discussion par recommending Padovan-Meth

Grohnfeldt, M. [Manfred] (2003). Beratung, Therapie und Rehabilitation. Lehrbuch der Sprachheilpädagogik und Logopädie: / Manfred Grohnfeldt (Hrsg.); Bd. 4. Stuttgart: Kohlhammer.

Gurfinkel, V., \& Grotti, A. Z. Método Padovan da Reorganização Neurofuncional. Retrieved from http://site.prosinapse.com.br/wpcontent/uploads/prosinapse_site/2016/12/sobrativivianegurfinkel.pdf

Hahn V. (1997). Oral stereognosis and orofacial dyskinesia: A clinical investigation. Sprache $\cdot$ Stimme $\cdot$ Gehör, 21(4), $185-191$.

Discussion par recommending Padovan-Meth

Items containir general inform: about the Padc Method ${ }^{\circledR}$

Discussion par recommending Padovan-Meth

Hahn, V., \& Hahn, H. (2007). Myofunktionelle Störungen. In M. Grohnfeldt (Ed.), Lexikon der Sprachtherapie (pp. 206-207). Kohlhammer Verlag.

Discussion par recommending Padovan-Meth

Hoke, F., \& Abad Bender, N. (2011). Interview. Die Padovan-Methode. Friederike Hoke interviewte Nicole Abad Bender. Logos interdisziplinär, 19(4), 301. Retrieved from http://www.zbmed.de/ccmedimages/2011/ZBMED-201112155157-5.pdf

Jasmin E., Beauregard F., \& Tetreault S. (2012). Neuromaturationnal intervention approaches: Analysis of theoretical and scientific foundations. ANAE - Approche Neuropsychologique Des Apprentissages Chez L'enfant, 24(116), 76-85.

Jausas, P. (2013). Prise en charge orthophonique de la deglutition atypique par la Methode Padovan®. Quelles critiques? Certificat de Capacité d'Orthophonie: Universitätsintern. Retrieved from nuxeo.edel.univ-poitiers.fr/nuxeo/site/esupversions/7b7e2634-3868-402bb668-705cc208bf81

Júnior, P. (2010). Com o método Padovan todo o sistema nervoso é estimulado Entrevista com lolanda Bezerra Costa. Retrieved from http://site.prosinapse.com.br/wp-content/uploads/prosinapse_site/2016/12/entrevistaiolandabezerra.pdf

Jutras, A. E., Boyer, J. A., Borduas, V., Pandev-Girard, B., Robitaille-Beaumier, E. L., Larivière, N., \& Jasmin, E. (2012). The Padovan ${ }^{2 m}$ Neurofunctional Reorganization Method: Exploring Its Application, Effects, and Appreciation in Children With Autism Spectrum Disorder [French]. Symposium annuel des programmes d'ergothérapie et de physiothérapie de l'Université de Sherbrooke. Retrieved from https://www.usherbrooke.ca/readaptation/fileadmin/sites/readaptation/documents/Resumes_de_recherches/La_methode_Pandovan.pdf

Kannegiesser-Leitner, C., \& Warnke, R. Hemoencephalography: A Practical Approach to Neurofeedback Training. In International Society for Neurofeedback and Research (Ed.), Neuroconnections: A joint newsletter from the ISNR \& the AAPB Neurofeedback Division (pp. 23-29). San Rafael, CA. Retrieved from https://docs.wixstatic.com/ugd/cba323_13cb20b8c4ee4b1c8e8c8135440d51c7.pdf

Kesper, G., \& Achenbach, B. (Eds.) (2002). Heilpädagogik. Sensorische Integration und Lernen: Grundlagen, Diagnostik und Förderung. München: Reinhardt.

Klein, S. (1995). Orofaciale Dysfunktion - ein interdisziplinäres Aufgabenfeld mit spezieller Berücksichtigung der "Integrierten Myoneurotherpie" von Beatriz Alves de Edmir Padovan: Diplomarbeit im Fach Heilpädagogik vrogelegt für die Diplomprüfung, Köln.

Klocke, A., Korbmacher, H., \& Kahl-Nieke, B. (2000). Der Status der myofunktionellen Therapie im Rahmen der interdisziplinären Zusammenarbeit aus der Sicht des Muskelfunktionstherapeuten. Sprache · Stimme - Gehör, 24(1), 38-43. https://doi.org/10.1055/s-200011066

Le Pottier, M. (2010). Troubles envahissants du développement et réorganisation neurofonctionnelle méthode Padovan: quels apports pour la prise en charge orthophonique?: étude longitudinale de la prise en charge orthophonique de sujets TED dans le cadre de la méthode Padovan: Etude longitudinale de la prise en charge orthophonique de sujets TED dans le cadre de la méthode Padovan. (Mémoire présenté pour l'obtention du Certificat de Capacité d'Orthophonie). Université de Lille II, Lille.

Lemer, P. S. (2019). Outsmarting autism: Updated and expanded : build healthy foundations for communication, socialization, and behavior at all ages. Berkeley, California: North Atlantic Books.
Items containir general inform about the Padc Method $\AA$

Discussion par recommending Padovan-Meth

Study - exclud $\epsilon$ to language res

Items containir general inform about the Padc Method $\circledast$

Study anouncement/ - no fulltext av

Unspecified information ab method

Discussion par recommending Padovan-Meth

Discussion par recommending Padovan-Meth

Mentioning $\mathrm{Pa}$ Method $\circledast$

Study - exclud $\epsilon$ to language res

Discussion par recommending Padovan-Meth 
Levrini, L., Lorusso, P., Caprioglio, A., Magnani, A., Diaféria, G., Bittencourt, L., \& Bommarito, S. (2014). Model of oronasal rehabilitation in children with obstructive sleep apnea syndrome undergoing rapid maxillary expansion: Research review. Sleep Science (Sao Paulo, Brazil), 7(4), 225-233. https://doi.org/10.1016/j.slsci.2014.11.002

Limbrock, J. (2017). Mundmotorik: Empfehlungen für Babys und Kleinkinder mit Störungen der oralen Funktion. Osteopathische Medizin, 18(3), 38-41. https://doi.org/10.1016/S1615-9071(17)30083-7

Loyer, N. (2011). Influences posturales et neurophysiologiques sur les fonctions oro-faciales: étude de prises en charge en réorganisation neuro-fonctionnelle dans le cadre de pathologies lourdes. Université Louis Pasteur, Strasbourg.

Machado, O. D.-V., Grande, S., Menezes, E., Fróes do Nascimento, L., \& Jungen, R. (69). Projekt zur Krisensituation der Spitalüberlastungen in Brasilien - Einführung der Anthroposophischen Medizin im öffentlichen Staats - spital Andaraí, Rio de Janeiro, Brasilien. Der Merkurstab, 2016(1), 60-61. Retrieved from https://www.anthromedics.org/DMS-20591-DE

Marjorie, S. (2014). La Méthode Padovan pour votre enfant autiste. Retrieved from http://site.prosinapse.com.br/wpcontent/uploads/prosinapse_site/2016/12/laméthodepourvotreenfantautiste.pdf

Discussion par recommending Padovan-Meth

Discussion par recommending Padovan-Meth

Study - exclud $\epsilon$ to language res

Discussion par recommending Padovan-Meth

Unspecified information ab method
Meilinger, M. (1999). Untersuchung ausgewäh/ter Aspekte myofunktioneller Störungen im Vorschulalter. Zugl.: München, Univ., Diss, 1999. Medizin. München: Utz Wiss.

Millette, C., Guillem, F., \& Stip, E. (2010). The Effects Of Neurofunctional Reorganization Therapy On Corporal Schema And Sensory Integration In Schizophrenic Patients: A PILOT STUDY. Schizophrenia Research, 117(2-3), 319.

https://doi.org/10.1016/j.schres.2010.02.541

Montpetit, L. (2012). Breaking Free from Persistent Fatigue. London: Jessica Kingsley Publishers. Retrieved from http://site.ebrary.com/lib/alltitles/docDetail.action?doclD $=10572470$

Montpetit, L. La réorganisation neuro-fonctionnelle. Le Lundi. Retrieved from http://site.prosinapse.com.br/wpcontent/uploads/prosinapse_site/2016/12/psychosanté.pdf

Morral Subirà, À., \& Pallàs Troyano, F. (2017). Padovan desde una óptica relacional: una experiencia con niños pequeños con TEA: Padovan Method From a Relational Perspective: An Experience With Little Children With ASD. Revista Iberoamericana de Psicomotricidad y Técnicas Corporales, 42, 163-175.

Moser-Dobis, C. (2011). Neurofunktionelle Reorganisation - Die "Padovan Methode" als therapeutische Möglichkeit in der Sprachrehabilitation? Sprachheilarbeit : Fachzeitschrift für Sprachheilpädagogik und akademische Sprachtherapie, 56(1), 18-22.

Neto, José Ribeiro da Silva, Picanço, K. R. T., Moreira, Y. P., Andrade, A. C. de, Oliveira, C. A. de, \& de Almeida, Ariely Nunes Ferreira (2016). Efeito do Método Padovan em Ambientes Clínicos:: Uma Revisão da Literatura. Cadernos De Educação, Saúde E Fisioterapia, $3(6 s u p l), 18$. https://doi.org/10.18310/2358-8306.v3n6supl

Padovan, B. A. E. (1976). Reeducação mioterápica nas pressões atípicas de língua: diagnóstico e terapêutica (H. von Treuenfels, Trans.) [Die Schluckfehlfunktion.]. Revista Ortodontia De São Paulo, 9(1+2).

Padovan, B. A. E. (1982). Die Entwicklung der Bewegung als Grundlage für die Sprache. Weleda-Nachrichten. (148), 11-14.

Padovan, B. A. E. (1994). Reorganização Neurofuncional - Método Padovan.: Temas sobre Desenvolvimento. São Paulo: Memnon Edições Científicas, 17(3), 13-21. Retrieved from

https://docplayer.com.br/storage/64/51446212/1553038060/Pu56n2W0MQs53DNe50tDUQ/51446212.pdf

Padovan, B. A. E. (1995). Réorganisation neurofonctionnelle (Méthode Padovan). Les Cahiers De Médecine Anthroposophique, 68.

Padovan, B. A. E. (1996, March). Terapia Miofuncional Orofacial - Método Padovan (Reorganização Neurofuncional): Segundo Artigo. Congresso Internacional de Fonoaudiologia de Guadeloupe, Guadeloupe. Retrieved from http://site.prosinapse.com.br/wpcontent/uploads/prosinapse_site/2016/12/1996-Terapia-iofuncional-Orofacial.pdf

Padovan, B. A. E. (1997a). Reorganização Neurofuncional-Método Padovan. Jornal Brasileiro De Ortodontia E Ortopedia Maxilar. (10), 311. Retrieved from https://sincroniayoga.com/wp-content/uploads/2016/05/Beatriz-Padovan-article.pdf

Padovan, B. A. E. (1997b). Wie wichtig ist die Kommunikation für die Plastizität des Nervensystems? Neurofunktionelle Reorganisation Padovan-Methode.: Kongressbeitrag. In Wege zur Kommunikation: Kongressband. I. Kongress der Diplomierten Logopädinnen für Österreich - September 1996. (Vol. 1, p. 37). Wien. ${ }^{a}$
Mentioning Pa Method®

Study anouncement/ - no fulltext av

Discussion par recommending Padovan-Meth

Unspecified information ab method

Study - exclud $\epsilon$ to language res

Items containir general inform about the Padc Method ${ }^{\circledR}$

Systematic Re anouncement/

- no fulltext av

Discussion par recommending Padovan-Meth

Items containir general inform about the Padc Method ${ }^{\circledR}$

Items containir general inform about the Padc Method $\AA$

Items containir general inform: about the Padc Method $\circledast$

Items containir general inform about the Padc Method ${ }^{\circledR}$

Items containir general inform about the Padc Method $\circledast$

Items containir general inform about the Padc Method $\circledast$ 
Padovan, B. A. E. (2007). El método Padovan como sistema terapéutico para las alteraciones funcionales orales y paraorales. In Congreso Interno Ortopedia y Ortodoncia. Montevideo, IUCEDDU.

Padovan, B. A. E. (2013). Método Padovan-Reorganização Neurofuncional. Vila Velha: Above Publicações.

Items containir general inform: about the Padc Method $\circledast$

Padovan, S. (2007). L'efficacité de la Méthode Padovan de réorganisation neuro-fonctionnelle. Inmare.

Pereira dos Santos, C., Torrieri Nigro, A., Falcão de Almeida, J., de Oliveira Martinez, Maria Lúcia, \& Ghelman, R. (2017). 0 método Padovan de reorganização neurofuncional sob a ótica da fenomenologia da trimembração pela medicina antroposófica: The Padovan method of neurofunctional reorganization from the perspective of the threefold phenomenology of anthroposophic medicine. Arte Médica Ampliada, 37(4), 115-117. Retrieved from http://abmanacional.com.br/wp-content/uploads/2019/01/37-4-Me\%CC\%81todo-Padovan.pdf

Items containir general inform about the Padc Method ${ }^{\circ}$

Rocher, S. (2011). Reeducation D'Une Langue Basse Parla Methode Padovan (Travail de Fin d'Etudes). Ecole Supérierue de Logopedie, Villle de Liège.

Discussion par recommending Padovan-Meth

Rohrer, T., Jung, A.-M., Muche-Borowski (Methodik/AWMF), C., Wilken, E., Mehl, B., Hammersen, G., ... Wachowsky, M. (2016). DownSyndrom im Kindes- und Jugendalter: Konsensbasierte Leitlinie (S2k) der Deutschen Gesellschaft für Kinder- und Jugendmedizin (DGKJ) und der beteiligten Fachgesellschaften, Berufsverbände und weiterer Organisationen. AWMF Online Www.Awmf.Org/leitlininien/detail/II/027-051.Html. Retrieved from https://www.awmf.org/uploads/tx_szleitlinien/027-051I_S2k_DownDiscussion par recommending Padovan-Meth Syndrom-Kinder-Jugendliche_2016-09-verlaengert.pdf

Sadowska, J., Dragun, G., Gutowska, A., \& Szczepaniak, R. (2016). Znaczenie prawidłowej postawy ciała podczas ćwiczeń logopedycznych. In Forum Logopedyczne

Schönfeld, A. (2013). Ist es möglich, ganzheitlich orientierte Therapiemethoden in ihrer gesamten Dimension diagnostisch zu erfassen, um diese im Rahmen der evidenzbasierten Medizin nach wissenschaftlichen Kriterien zu evaluieren?: Eine quantitative Datenanalyse am exemplarischen Beispiel der Neurofunktionellen Reorganisation (NFR®) nach Beatriz Padovan. Bachelorarbeit. Hamburg: Universitätsintern.

Starrost, U., \& Schilling, B. (2013). Therapiekonzepte in der Dysphagietherapie - ein Überblick. Neuroreha, 05(04), $176-183$. https://doi.org/10.1055/s-0033-136303

Suchodoletz, W. von (2007). Lese-Rechtschreib-Störung (LRS) - Fragen und Antworten: Eine Orientierungshilfe für Betroffene, Eltern und Lehrer (1. Aufl.). Rat \& Hilfe. Stuttgart: Kohlhammer.

Suchodoletz, W. von (2010). Alternative Therapiemethoden. In W. von Suchodoletz (Ed.), Therapie von Entwicklungsstörungen: Was wirkt wirklich? (pp. 231-254). Göttingen, Bern, Wien, Paris, Oxford, Prag, Toronto, Cambridge, Mass., Amsterdam, Kopenhagen, Stockholm: Hogrefe.

Suchodoletz, W. von (2013a). Sprech- und Sprachentwicklungsstörungen. In F. Petermann (Ed.), Lehrbuch der Klinischen Kinderpsychologie (7th ed., pp. 229-243). Göttingen: Hogrefe.

Mentioning $\mathrm{Pa}$ Method®

Items containir general inform: about the Padc Method $\circledast$

Mentioning $\mathrm{Pa}$ Method $\AA$

Mentioning $\mathrm{Pa}$ Method ${ }^{\circledR}$

Mentioning $\mathrm{Pa}$ Method ${ }^{\circ}$

Discussion par recommending Padovan-Meth

Suchodoletz, W. von (2013b). Sprech- und Sprachstörungen. Leitfaden Kinder- und Jugendpsychotherapie: Band 18. Göttingen, Bern, Wien: Hogrefe.

Suchodoletz, W. von (2015). Sprachentwicklungsstörungen. In G. F. Hoffmann, M. J. Lentze, J. Spranger, \& F. Zepp (Eds.), Pädiatrie (pp. 14). Berlin, Heidelberg: Springer Berlin Heidelberg. https://doi.org/10.1007/978-3-642-54671-6_282-1

Suchodoletz, W. von, \& Amorosa, H. (2006). Therapie der Lese-Rechtschreib-Störung (LRS): Traditionelle und alternative Behandlungsmethoden im Überblick (2., überarb. und erw. Aufl.). Klinische Psychologie Kindes- u. Jugendalter. Stuttgart: Kohlhammer. Retrieved from http://www.content-select.com/index.php?id=bib_view\&ean=9783170227453

Treuenfels, H. von (2014). Der Beitrag der Systemischen Kieferorthopädie für Schlaf und Gesundheit. Zeitschrift Für Komplementärmedizin, 06(04), 23-29. https://doi.org/10.1055/s-0034-1386739

Treuenfels, H. von (Ed.) (2017). Gesund beginnt im Mund: Warum Zähneknirschen zu Rückenschmerzen führt und Lachen den Blutdruck reguliert (Originalausgabe). München: Knaur MensSana.

Treuenfels, H. von. Die neue Biognathe Orthese und Padovan Übungen. GZM Praxis Und Wissenschaft, 7(1), 65.

Ullrich, D., Ullrich, K., \& Marten, M. (2009). Schulentwicklung bei Kindern mit schweren Sprachentwicklungsstörungen Nachbeobachtung bis zu 15 Jahren nach Entlassung aus Sprachheilkindergärten [Long-term school-development of children with impaired language skills: 15-years follow up after dismissal from child care centres with speech therapy]. Laryngo- rhino- otologie, 88(10), 647-652. https://doi.org/10.1055/s-0029-1220945

Vaineau, A.-L. (2016). La méthode Padovan, c'est quoi ? Retrieved from http://site.prosinapse.com.br/wpcontent/uploads/prosinapse_site/2016/12/laméthodepadovan.pdf
Discussion par recommending Padovan-Meth

Mentioning $\mathrm{Pa}$ Method ${ }^{\circledR}$

Mentioning $\mathrm{Pa}$ Method $\circledast$

Discussion par recommending Padovan-Meth

Discussion par recommending Padovan-Meth

Discussion par recommending Padovan-Meth

Discussion par recommending Padovan-Meth

Unspecified information ab method 
Weinrich, M., \& Zehner, H. (2017). Phonetische und phonologische Störungen bei Kindern: Aussprachetherapie in Bewegung (5. Aufl. 2017).

Praxiswissen Logopädie. Berlin, Heidelberg, s.I.: Springer Berlin Heidelberg. https://doi.org/10.1007/978-3-662-52773-3

Discussion par recommending Padovan-Meth

Wennekers-Rodenacker, M., \& Abad Bender, N. (2011). Anmerkungen zum Artikel: „Neurofunktionelle Reorganisation - Die „PadovanMethode" als therapeutische Möglichkeit in der Sprachrehabilitation" von Christine Moser- Dobis Sprachheilarbeit 56, 1, 2011, S. 18ff.

Sprachheilarbeit : Fachzeitschrift Für Sprachheilpädagogik Und Akademische Sprachtherapie, 56(4), 223.

Items containir general inform: about the Padc Method ${ }^{\circ}$

Notes. ${ }^{\text {a }}$ The existence of this resource is doubtful. Although published papers of the last decades cite this article, it was available nowhere. An inquiry at the Austrian association of logopaedics resulted, that there was no such congress. Nevertheless the reference is listed here to highlight this case [207].

\section{Appendix C: Rating instruments and authors judgments}

Table C1. Rating instruments used 


\begin{tabular}{|c|c|c|}
\hline Rating instrument & Source of description & Application \\
\hline AIMS (Alberta Infant Motor Scale) & described by [171] & $\begin{array}{l}\text { utilised in } \\
{[54]}\end{array}$ \\
\hline Arterial oxygen saturation (SpO) & & $\begin{array}{l}\text { utilised in } \\
{[44]}\end{array}$ \\
\hline Assessment of mouth closure by the therapists using a three point scale & described by [49] & $\begin{array}{l}\text { utilised in } \\
{[49]}\end{array}$ \\
\hline BOT-2 (Bruininks-Oseretsky Test of motoric proficiency) & described by [178] & $\begin{array}{l}\text { utilised in } \\
{[49]}\end{array}$ \\
\hline Coordination of tongue and lips using certain tasks from a toolkit & developed and described by [177] & $\begin{array}{l}\text { utilised in } \\
\text { [49] }\end{array}$ \\
\hline $\mathrm{DI}_{3}$ (desaturation index $\geq 3 \%$, events per hour of corrected estimated sleep time) & described by $[44,45]$ & $\begin{array}{l}\text { utilised in } \\
{[44]}\end{array}$ \\
\hline $\mathrm{DI}_{90}$ (desaturation index $<90 \%$, events per hour of corrected estimated sleep time & described by $[44,45]$ & $\begin{array}{l}\text { utilised in } \\
\text { [44] }\end{array}$ \\
\hline FAM (Functional Assessment Measure) & described by [185] & $\begin{array}{l}\text { utilised in } \\
{[46]}\end{array}$ \\
\hline FIM (Functional Independence Measure) & described by [186] & $\begin{array}{l}\text { utilised in } \\
\text { [46] }\end{array}$ \\
\hline IOPI (lowa Oral Performance Instrument) & described by [175] & $\begin{array}{l}\text { utilized in } \\
{[49]}\end{array}$ \\
\hline $\begin{array}{l}\text { IPVP ('Befund- und Verlaufsprotokoll zur Neurofunktionellen Reorganisation' / report sheet from } \\
\text { the results and progress log for neurofunctional reorganization) }\end{array}$ & described by $[129,181]$ & $\begin{array}{l}\text { utilised in } \\
{[36]}\end{array}$ \\
\hline JFK Coma Recovery Scale-Revised (CRS-R) & described by [183] & $\begin{array}{l}\text { utilised in } \\
\text { [46] }\end{array}$ \\
\hline $\begin{array}{l}\text { Kölner Diagnostikbogen (logopaedic assessment tool developed for quality assessment in } \\
\text { logopaedic therapies) }\end{array}$ & described by [180] & $\begin{array}{l}\text { utilised in } \\
{[36]}\end{array}$ \\
\hline LPB ('Lautprüfbogen' / articulation) & described by [169] & $\begin{array}{l}\text { utilised in } \\
\text { [49], }\end{array}$ \\
\hline $\begin{array}{l}\text { Measurement of suction power and speed using the suction trainer developed by Beatriz A. E. } \\
\text { Padovan }\end{array}$ & described by [10] & $\begin{array}{l}\text { utilised in } \\
{[49]}\end{array}$ \\
\hline $\begin{array}{l}\text { MFT-Lippenwage (lip strength using a tool to strengthen and measure the muscles for closure of } \\
\text { lip and mouth }\end{array}$ & described by [176] & $\begin{array}{l}\text { utilised in } \\
{[49]}\end{array}$ \\
\hline MOAHI (mixed-obstructive-apnoea/hypopnoea index) & $\begin{array}{l}\text { described by [179]; adapted as the } \\
\text { sum of obstructive and mixed } \\
\text { apnoeas and hypopneas per hour of } \\
\text { corrected estimated sleep time (CEST) } \\
\text { described by }[44,45]\end{array}$ & $\begin{array}{l}\text { utilised in } \\
\text { [44] }\end{array}$ \\
\hline МОТ 4-6 & described by [173] & $\begin{array}{l}\text { utilised in } \\
\text { [55] }\end{array}$ \\
\hline Neurological examinations & & $\begin{array}{l}\text { utilised in } \\
{[48]}\end{array}$ \\
\hline Observation of teeth and jaw position by therapists & described by [170] & $\begin{array}{l}\text { utilised in } \\
\text { [49] }\end{array}$ \\
\hline PACST (Putney Auditory Comprehension Screening Test) & described by [184] & $\begin{array}{l}\text { utilised in } \\
{[46]}\end{array}$ \\
\hline $\begin{array}{l}\text { Parental questionnaire regarding the development of the participants and their influence on the } \\
\text { family, self-developed }\end{array}$ & described by [55] and & $\begin{array}{l}\text { utilised in } \\
{[55]}\end{array}$ \\
\hline $\begin{array}{l}\text { Physical assessment (grab objects, reflux, don't follow objects, lack of cervical control, } \\
\text { convulsion/spasm, lack of thoracical control) }\end{array}$ & described by [54] & $\begin{array}{l}\text { utilised in } \\
{[54]}\end{array}$ \\
\hline SETK 3-5 ('Sprachentwicklungstest' / speech development test) & described by [174] & $\begin{array}{l}\text { utilised in } \\
{[55]}\end{array}$ \\
\hline Swallowing examination using a system with different types of fluid and colour & described by [170] & $\begin{array}{l}\text { utilised in } \\
\text { [49] }\end{array}$ \\
\hline 'Therapeutische Auftragsklärung' (a clarification of therapeutic objectives sheet) & following [180] & $\begin{array}{l}\text { utilised in } \\
{[36]}\end{array}$ \\
\hline $\begin{array}{l}\text { Therapists observation and parents questionnaire with the following items: time needed for } \\
\text { homework, concentration during homework, difficulties with orthography, difficulties with building } \\
\text { sentences, difficulties with finding the right words, building unstructured sentences, time to get up } \\
\text { in the morning, awakening during night, needed time to fall asleep, preference of certain food- } \\
\text { consistency, chewing }\end{array}$ & developed and described by [49] & $\begin{array}{l}\text { utilised in } \\
{[49]}\end{array}$ \\
\hline
\end{tabular}




\begin{tabular}{|ll|}
\hline Rating instrument & Source of description \\
\hline WHIM (Wessex Head Injury Matrix) & described by [182] \\
\hline
\end{tabular}

Table C2. Risk of bias, limitations and imprecision assessment Bellingen 2017

\begin{tabular}{|c|c|c|}
\hline Item & $\begin{array}{l}\text { Authors' } \\
\text { judgement }\end{array}$ & Support for judgement \\
\hline Bias due to confounding & Low risk & No obvious bias due to confounding. \\
\hline $\begin{array}{l}\text { Bias in selection of } \\
\text { participants }\end{array}$ & Low risk & No obvious bias in selection of participants. \\
\hline $\begin{array}{l}\text { Bias in classification of } \\
\text { interventions }\end{array}$ & Low risk & No obvious bias in classification of interventions. \\
\hline $\begin{array}{l}\text { Bias due to deviations from } \\
\text { intended interventions }\end{array}$ & Low risk & No obvious bias due deviations from intended interventions. \\
\hline Bias due to missing data & Low risk & No obvious bias due to missing data. \\
\hline $\begin{array}{l}\text { Bias in measurement of } \\
\text { outcomes }\end{array}$ & $\begin{array}{l}\text { Moderate } \\
\text { risk }\end{array}$ & $\begin{array}{l}\text { Outcome assessors aware of the intervention received. IOPI-tool turned out not to be appropriate to measure } \\
\text { outcome on pressure of tongue [170]. }\end{array}$ \\
\hline $\begin{array}{l}\text { Bias in selection of the } \\
\text { reported result }\end{array}$ & $\begin{array}{l}\text { Serious } \\
\text { risk }\end{array}$ & $\begin{array}{l}\text { A protocol is missing, to verify, that the reported results cover all intended outcomes. Outcomes are not } \\
\text { presented completely in the published version [49] in comparison to an older version [170]. }\end{array}$ \\
\hline Limitations & Moderate & Limitations are given due to a number of self-developed and not yet validated questionnaires and testing's. \\
\hline Imprecision & Low & $\mathrm{Cl}$ not defined in publication. \\
\hline
\end{tabular}

Notes. Authors' judgement and support for judgement regarding Bellingen 2017 [49].

Table C3. Risk of bias, limitations and imprecision assessment - Lukowicz 2019

\begin{tabular}{|lll|}
\hline Item & $\begin{array}{l}\text { Authors' } \\
\text { judgement }\end{array}$ & Support for judgement \\
\hline Bias due to confounding & $\begin{array}{l}\text { Moderate } \\
\text { risk }\end{array}$ & Effect of intervention might be confounded due to very short intervention protocol (one week). \\
\hline Bias in selection of participants & Low risk & No obvious bias in selection of participants. \\
\hline $\begin{array}{l}\text { Bias in classification of } \\
\text { interventions }\end{array}$ & Low risk & No obvious bias in classification of interventions. \\
\hline $\begin{array}{l}\text { Bias due to deviations from } \\
\text { intended interventions }\end{array}$ & Low risk & No obvious bias due deviations from intended interventions. \\
\hline $\begin{array}{l}\text { Bias due to missing data } \\
\begin{array}{l}\text { Bias in measurement of } \\
\text { outcomes }\end{array}\end{array}$ & Low risk & No obvious bias due to missing data. \\
\hline $\begin{array}{l}\text { Bias in selection of the reported } \\
\text { result }\end{array}$ & $\begin{array}{l}\text { Moderate } \\
\text { risk }\end{array}$ & $\begin{array}{l}\text { Outcome assessors aware of the intervention received. } \\
\text { from the published version [44] to an older version [45]. }\end{array}$ \\
\hline $\begin{array}{l}\text { Limitations } \\
\text { Imprecision }\end{array}$ & Low & \begin{tabular}{l} 
Limitation due to short study setup. \\
\hline
\end{tabular} \\
\hline
\end{tabular}

Notes. Authors' judgement and support for judgement regarding Lukowicz 2019 [44].

Table C4. Risk of bias, limitations and imprecision assessment - Pereira et al. 2015 


\begin{tabular}{|c|c|c|}
\hline Item & $\begin{array}{l}\text { Authors' } \\
\text { judgement }\end{array}$ & Support for judgement \\
\hline Bias due to confounding & $\begin{array}{l}\text { Critical } \\
\text { risk }\end{array}$ & Multi modal therapy setup making confounding not controllable. \\
\hline $\begin{array}{l}\text { Bias in selection of } \\
\text { participants }\end{array}$ & $\begin{array}{l}\text { Serious } \\
\text { risk }\end{array}$ & Selection of participants not clearly defined. Different time points of start of follow up and start of intervention. \\
\hline $\begin{array}{l}\text { Bias in classification of } \\
\text { interventions }\end{array}$ & Low risk & No obvious bias in classification of interventions. \\
\hline $\begin{array}{l}\text { Bias due to deviations } \\
\text { from intended } \\
\text { interventions }\end{array}$ & $\begin{array}{l}\text { Critical } \\
\text { risk }\end{array}$ & Substantial imbalances in important co-interventions and lacking of appropriate analysis. \\
\hline Bias due to missing data & $\begin{array}{l}\text { Critical } \\
\text { risk }\end{array}$ & No data of outcomes measurement was available at all. \\
\hline $\begin{array}{l}\text { Bias in measurement of } \\
\text { outcomes }\end{array}$ & $\begin{array}{l}\text { Serious } \\
\text { risk }\end{array}$ & $\begin{array}{l}\text { Outcome assessors aware of the intervention received. Measurement was subjective and no parameters were } \\
\text { documented. }\end{array}$ \\
\hline $\begin{array}{l}\text { Bias in selection of the } \\
\text { reported result }\end{array}$ & $\begin{array}{l}\text { Critical } \\
\text { risk }\end{array}$ & $\begin{array}{l}\text { A protocol is missing, to verify, that the reported results cover all intended outcomes. As almost none } \\
\text { measurements or parameters of outcomes were documented, strong suspicion of selective reporting is present. }\end{array}$ \\
\hline Limitations & High & Unclear intervention protocol and missing outcome values. \\
\hline Imprecision & High & No operationalizable values and data available regarding outcomes. Results presented in prose. \\
\hline
\end{tabular}

Notes. Authors' judgement and support for judgement regarding Pereira et al. 2015 [48].

Table C5. Risk of bias, limitations and imprecision assessment - Rodenacker 2007

\begin{tabular}{|c|c|c|}
\hline Item & $\begin{array}{l}\text { Authors' } \\
\text { judgement }\end{array}$ & Support for judgement \\
\hline $\begin{array}{l}\text { Bias due to } \\
\text { confounding }\end{array}$ & $\begin{array}{l}\text { Critical } \\
\text { risk }\end{array}$ & $\begin{array}{l}\text { Setup was multimodal. Confounding interventions were not controlled in the analysis. Participants were partly } \\
\text { bilingual making interaction between advisor and participant difficult. Measurements were partly affected by } \\
\text { participants having a flu. }\end{array}$ \\
\hline $\begin{array}{l}\text { Bias in selection of } \\
\text { participants }\end{array}$ & Low risk & No obvious bias in selection of participants. \\
\hline $\begin{array}{l}\text { Bias in classification } \\
\text { of interventions }\end{array}$ & Low risk & No obvious bias in classification of interventions. \\
\hline $\begin{array}{l}\text { Bias due to deviations } \\
\text { from intended } \\
\text { interventions }\end{array}$ & $\begin{array}{l}\text { Moderate } \\
\text { risk }\end{array}$ & Co-interventions were not balanced across all participants. \\
\hline $\begin{array}{l}\text { Bias due to missing } \\
\text { data }\end{array}$ & Low risk & No obvious bias due to missing data. \\
\hline $\begin{array}{l}\text { Bias in measurement } \\
\text { of outcomes }\end{array}$ & $\begin{array}{l}\text { Serious } \\
\text { risk }\end{array}$ & $\begin{array}{l}\text { Outcome assessors aware of the intervention received. Language barriers between assessors and participants } \\
\text { made the measurements difficult. }\end{array}$ \\
\hline $\begin{array}{l}\text { Bias in selection of } \\
\text { the reported result }\end{array}$ & $\begin{array}{l}\text { Moderate } \\
\text { risk }\end{array}$ & A protocol is missing, to verify, that the reported results cover all intended outcomes. \\
\hline Limitations & High & Limitations due to multimodal setup and confounding interventions. \\
\hline Imprecision & Moderate & $\begin{array}{l}\mathrm{Cl} \text { was set to } 95 \% \text { but measurement of outcomes underlying a serious risk of bias as well as present risk of bias } \\
\text { due to confounding. }\end{array}$ \\
\hline
\end{tabular}

Notes. Authors' judgement and support for judgement regarding Rodenacker 2007 [55].

Table C6. Limitations and imprecision assessment-Barbosa 2019 


\begin{tabular}{|c|c|c|}
\hline Item & Authors' judgement & Support for judgement \\
\hline Limitations & High & $\begin{array}{l}\text { More than two items of the CARE-Guideline regarding each of the following domains not documented: } \\
\text { - } \quad \text { diagnostic assessment } \\
\text { - } \quad \text { follow-up and outcomes } \\
\text { - } \quad \text { discussion } \\
\text { Insufficient adherence to the CARE-domain 'patient perspective'. }\end{array}$ \\
\hline Imprecision & High & No operationalizable values and data available regarding outcomes. Results presented in prose. \\
\hline
\end{tabular}

Notes. Authors' judgement and support for judgement regarding Barbosa 2019 [50].

Table C7. Limitations and imprecision assessment - Braga 2019

\begin{tabular}{|c|c|c|}
\hline Item & Authors' judgement & Support for judgement \\
\hline Limitations & High & $\begin{array}{l}\text { More than two items of the CARE-Guideline regarding each of the following domains not documented: } \\
\text { - } \quad \text { diagnostic assessment } \\
\text { - } \quad \text { follow-up and outcomes } \\
\text { - } \quad \text { discussion } \\
\text { Timeline partly missing. } \\
\text { Insufficient adherence to the CARE-domain 'patient perspective'. }\end{array}$ \\
\hline Imprecision & High & No operationalizable values and data available regarding outcomes. Results presented in prose. \\
\hline
\end{tabular}

Notes. Authors' judgement and support for judgement regarding Braga 2019 [51].

Table C8. Limitations and imprecision assessment - Buson 2019

\begin{tabular}{|c|c|c|}
\hline Item & Authors' judgement & Support for judgement \\
\hline Limitations & High & $\begin{array}{l}\text { More than two items of the CARE-Guideline regarding each of the following domains not documented: } \\
\text { - } \quad \text { diagnostic assessment } \\
\text { - follow-up and outcomes } \\
\text { Tiscussion } \\
\text { Timeline partly missing. } \\
\text { Insufficient adherence to the CARE-domain 'patient perspective'. }\end{array}$ \\
\hline Imprecision & High & No operationalizable values and data available regarding outcomes. Results presented in prose. \\
\hline
\end{tabular}

Notes. Authors' judgement and support for judgement regarding Buson 2019 [52].

Table C9. Limitations and imprecision assessment - Carmo 2019

\begin{tabular}{|c|c|c|}
\hline Item & Authors' judgement & Support for judgement \\
\hline Limitations & High & $\begin{array}{l}\text { More than two items of the CARE-Guideline regarding each of the following domains not documented: } \\
\text { - } \quad \text { diagnostic assessment } \\
\text { - } \quad \text { dillow-up and outcomes } \\
\text { Timeline partly missing. } \\
\text { Insufficient adherence to the CARE-domain 'patient perspective'. }\end{array}$ \\
\hline Imprecision & High & No operationalizable values and data available regarding outcomes. Results presented in prose. \\
\hline
\end{tabular}


Notes. Authors' judgement and support for judgement regarding Carmo 2019 [53].

Table C10. Limitations and imprecision assessment - Delmondes 2018

\begin{tabular}{|c|c|c|}
\hline Item & Authors' judgement & Support for judgement \\
\hline Limitations & High & $\begin{array}{l}\text { More than two items of the CARE-Guideline regarding each of the following domains not documented: } \\
\text { - } \quad \text { diagnostic assessment } \\
\text { - } \quad \text { follow-up and outcomes } \\
\text { Timeline missing. } \\
\text { Insufficient adherence to the CARE-domain 'patient perspective'. }\end{array}$ \\
\hline Imprecision & High & No operationalizable values and data available regarding outcomes. Results presented in prose. \\
\hline
\end{tabular}

Notes. Authors' judgement and support for judgement regarding Delmondes 2018 [47].

Table C11. Limitations and imprecision assessment - Froitzheim 2010

\begin{tabular}{|c|c|c|}
\hline Item & Authors' judgement & Support for judgement \\
\hline Limitations & High & $\begin{array}{l}\text { More than two items of the CARE-Guideline regarding each of the following domains not documented: } \\
\text { - diagnostic assessment } \\
\text { - follow-up and outcomes } \\
\text { Tiscussion } \\
\text { Insufficient adherence to the CARE-domain 'patient perspective'. }\end{array}$ \\
\hline
\end{tabular}

Notes. Authors' judgement and support for judgement regarding Froitzheim 2010 [164].

Table C12. Limitations and imprecision assessment - Großweischede 2000

\begin{tabular}{|lll|}
\hline \multicolumn{2}{|l|}{ Authors' judgement } & Support for judgement \\
\hline Limitations & Moderate & More than two items of the CARE-Guideline regarding the domain 'diagnostic assessment'. \\
\hline Imprecision & High & No operationalizable values and data available regarding outcomes. Results presented in prose. \\
\hline
\end{tabular}

Notes. Authors' judgement and support for judgement regarding Großweischede 2000 [165].

Table C13. Limitations and imprecision assessment - Kunert 2003

\begin{tabular}{|c|c|c|}
\hline Item & Authors' judgement & Support for judgement \\
\hline Limitations & Moderate & $\begin{array}{l}\text { More than two items of the CARE-Guideline regarding each of the following domains not documented: } \\
\text { - } \quad \text { follow-up and outcomes } \\
\text { - discussion } \\
\text { Timeline missing. } \\
\text { Limited adherence to the CARE-domain 'patient perspective'. }\end{array}$ \\
\hline Imprecision & High & No operationalizable values and data available regarding outcomes. Results presented in prose. \\
\hline
\end{tabular}

Notes. Authors' judgement and support for judgement regarding Kunert 2003 [166].

Table C14. Limitations and imprecision assessment - Menezes 2019

Page 38/66 


\begin{tabular}{|c|c|c|}
\hline Item & $\begin{array}{l}\text { Authors' } \\
\text { judgement }\end{array}$ & Support for judgement \\
\hline Limitations & Moderate & $\begin{array}{l}\text { More than two items of the CARE-Guideline regarding each of the following domains not documented: } \\
\text { - } \quad \text { diagnostic assessment } \\
\text { - } \quad \text { follow-up and outcomes }\end{array}$ \\
\hline Imprecision & Moderate & $\begin{array}{l}\text { Operationalizable values and data available regarding outcomes available. Methodology not precise and detailed } \\
\text { analysis missing. }\end{array}$ \\
\hline
\end{tabular}

Notes. Authors' judgement and support for judgement regarding Menezes 2019 [54].

Table C15. Limitations and imprecision assessment - Oertel 2015

\begin{tabular}{|lll|}
\hline Item & $\begin{array}{c}\text { Authors' } \\
\text { judgement }\end{array}$ & Support for judgement \\
\hline Limitations & Moderate & More than two items of the CARE-Guideline regarding the domain 'follow-up and outcomes'. \\
\hline Imprecision & Moderate & $\begin{array}{l}\text { Operationalizable values and data available regarding outcomes available. Methodology not precise and detailed analysis } \\
\text { missing. Confounding comparison of outcome measurements and correction available in the included erratum. }\end{array}$ \\
\hline
\end{tabular}

Notes. Authors' judgement and support for judgement regarding Oertel 2015 [36].

Table C16. Limitations and imprecision assessment - Oliveira 2019

\begin{tabular}{|c|c|c|}
\hline Item & Authors' judgement & Support for judgement \\
\hline Limitations & Moderate & $\begin{array}{l}\text { More than two items of the CARE-Guideline regarding the domain 'follow-up and outcomes'. } \\
\text { Insufficient adherence to the CARE-domain 'patient perspective'. }\end{array}$ \\
\hline Imprecision & High & No operationalizable values and data available regarding outcomes. Results presented in prose. \\
\hline
\end{tabular}

Notes. Authors' judgement and support for judgement regarding Oliveira 2019 [72].

Table C17. Limitations and imprecision assessment - Pereira 2015

\begin{tabular}{|c|c|c|}
\hline Item & Authors' judgement & Support for judgement \\
\hline Limitations & High & $\begin{array}{l}\text { More than two items of the CARE-Guideline regarding each of the following domains not documented: } \\
\text { - diagnostic assessment } \\
\text { - follow-up and outcomes } \\
\text { Tiscussion } \\
\text { Insufficient adherence to the CARE-domain 'patient perspective'. }\end{array}$ \\
\hline Imprecision & High & No operationalizable values and data available regarding outcomes. Results presented in prose. \\
\hline
\end{tabular}

Notes. Authors' judgement and support for judgement regarding Pereira 2015 [22].

Table C18. Limitations and imprecision assessment - Pereira 2018

\begin{tabular}{|lll|}
\hline \multicolumn{2}{|l|}{ Authors' judgement } & Support for judgement \\
\hline Limitations & Moderate & $\begin{array}{l}\text { More than two items of the CARE-Guideline regarding the domain 'follow-up and outcomes'. } \\
\text { Insufficient adherence to the CARE-domain 'patient perspective'. }\end{array}$ \\
\hline Imprecision & High & No operationalizable values and data available regarding outcomes. Results presented in prose. \\
\hline
\end{tabular}

Notes. Authors' judgement and support for judgement regarding Pereira 2018 [167].

Table C19. Limitations and imprecision assessment - Wilson 2016

Page 39/66 


\begin{tabular}{|lll|}
\hline \multicolumn{2}{|l|}{ Authors' judgement } & Support for judgement \\
\hline Limitations & Moderate & $\begin{array}{l}\text { Insufficient adherence to the CARE-Guideline regarding the domain 'follow-up and outcomes'. } \\
\text { Insufficient adherence to the CARE-domain 'patient perspective'. }\end{array}$ \\
\hline Imprecision & High & No operationalizable values and data available regarding outcomes. Results presented in prose. \\
\hline
\end{tabular}

Notes. Authors' judgement and support for judgement regarding Wilson 2016 [46].

Table C20. Table of primary outcomes qualitatively described 


\begin{tabular}{|c|c|c|c|c|c|c|c|c|c|c|c|c|}
\hline \multirow[t]{2}{*}{ Item } & \multicolumn{3}{|c|}{ Primary outcomes } & \multirow[t]{2}{*}{$\Sigma$} & \multicolumn{4}{|l|}{ Studies } & \multicolumn{4}{|c|}{ Case Reports } \\
\hline & $\begin{array}{l}\text { early } \\
\text { response, } \\
\text { between } \\
\text { one and } \\
\text { four } \\
\text { weeks }\end{array}$ & $\begin{array}{l}\text { acute } \\
\text { phase } \\
\text { treatment } \\
\text { response } \\
\text { between } \\
\text { six and } \\
12 \text { weeks }\end{array}$ & $\begin{array}{l}\text { long- } \\
\text { term and } \\
\text { follow- } \\
\text { up } \\
\text { response } \\
\text { between } \\
\text { four and } \\
\text { six } \\
\text { months } \\
\text { (or } \\
\text { more) }\end{array}$ & & $\begin{array}{l}\text { Bellingen } \\
2017 \\
{[49]}\end{array}$ & $\begin{array}{l}\text { Lukowitz } \\
2019 \\
{[44]}\end{array}$ & $\begin{array}{l}\text { Pereira } \\
\text { et al. } \\
2015 \\
{[48]}\end{array}$ & $\begin{array}{l}\text { Rodenacker } \\
2007 \text { [55] }\end{array}$ & $\begin{array}{l}\text { Barbosa } \\
2019 \\
{[50]}\end{array}$ & $\begin{array}{l}\text { Braga } \\
2019 \\
{[51]}\end{array}$ & $\begin{array}{l}\text { Buson } \\
2019 \\
{[52]}\end{array}$ & $\begin{array}{l}\text { Carmo } \\
2019 \\
{[53]}\end{array}$ \\
\hline \multicolumn{13}{|l|}{ motoric functions } \\
\hline $\begin{array}{l}\text { impr of muscle } \\
\text { tone }\end{array}$ & $x$ & $x$ & $x$ & 5 & & & & $x$ & $x$ & & & \\
\hline $\begin{array}{l}\text { impr of motoric } \\
\text { development }\end{array}$ & $x$ & $x$ & $x$ & 4 & & & & & & $x$ & $x$ & \\
\hline $\begin{array}{l}\text { impr of } \\
\text { stiffness }\end{array}$ & $x$ & $x$ & $x$ & 3 & & & & & & & & $x$ \\
\hline impr of posture & & $x$ & $x$ & 3 & & & & & & & & $x$ \\
\hline $\begin{array}{l}\text { impr of cervical } \\
\text { control }\end{array}$ & & $x$ & $x$ & 2 & & & & & & & & $x$ \\
\hline $\begin{array}{l}\text { impr of eye- } \\
\text { hand- } \\
\text { coordination }\end{array}$ & & & $x$ & 2 & & & & & & & & \\
\hline $\begin{array}{l}\text { progr of } \\
\text { learning to } \\
\text { walk in c }\end{array}$ & $x$ & & $x$ & 2 & & & & & & & & \\
\hline $\begin{array}{l}\text { progr of } \\
\text { crawling in c }\end{array}$ & $x$ & & $x$ & 2 & & & & & & & & \\
\hline $\begin{array}{l}\text { progr of sitting } \\
\text { in c }\end{array}$ & $x$ & & $x$ & 2 & & & & & & & & \\
\hline less spasms & & & $x$ & 1 & & & & & & & & \\
\hline $\begin{array}{l}\text { less tension } \\
\text { and pain }\end{array}$ & & & $x$ & 1 & & & & & & & & \\
\hline $\begin{array}{l}\text { impr of } \\
\text { thoracical } \\
\text { control }\end{array}$ & & & $x$ & 1 & & & & & & & & \\
\hline $\begin{array}{l}\text { progr of rolling } \\
\text { in } \mathrm{C}\end{array}$ & & & $x$ & 1 & & & & & & & & \\
\hline \multirow[t]{2}{*}{$\begin{array}{l}\text { impr of axial } \\
\text { symmetry }\end{array}$} & & & $x$ & 1 & & & & & & & & \\
\hline & & & & & & & & & \multicolumn{4}{|c|}{ psychomotor development } \\
\hline $\begin{array}{l}\text { impr of } \\
\text { cognition }\end{array}$ & $x$ & $x$ & $x$ & 3 & & & & & & & $x$ & \\
\hline $\begin{array}{l}\text { impr of } \\
\text { interaction }\end{array}$ & $x$ & $x$ & $x$ & 3 & & & & & & & $x$ & \\
\hline $\begin{array}{l}\text { impr of } \\
\text { concentration }\end{array}$ & & & $x$ & 2 & & & & & $x$ & & & \\
\hline $\begin{array}{l}\text { impr of } \\
\text { comprehension }\end{array}$ & & & $x$ & 2 & & & & & $x$ & & & \\
\hline $\begin{array}{l}\text { watching } \\
\text { object }\end{array}$ & $x$ & & $x$ & 2 & & & & & & & & \\
\hline $\begin{array}{l}\text { psychomotor } \\
\text { skills }\end{array}$ & & $x$ & $x$ & 2 & & & & & & & $x$ & \\
\hline $\begin{array}{l}\text { impr of hearing } \\
\text { in newb }\end{array}$ & $x$ & $x$ & & 2 & & & $x$ & & & & & \\
\hline $\begin{array}{l}\text { impr of seeing } \\
\text { in newb }\end{array}$ & $x$ & $x$ & & 2 & & & $x$ & & & & & \\
\hline
\end{tabular}




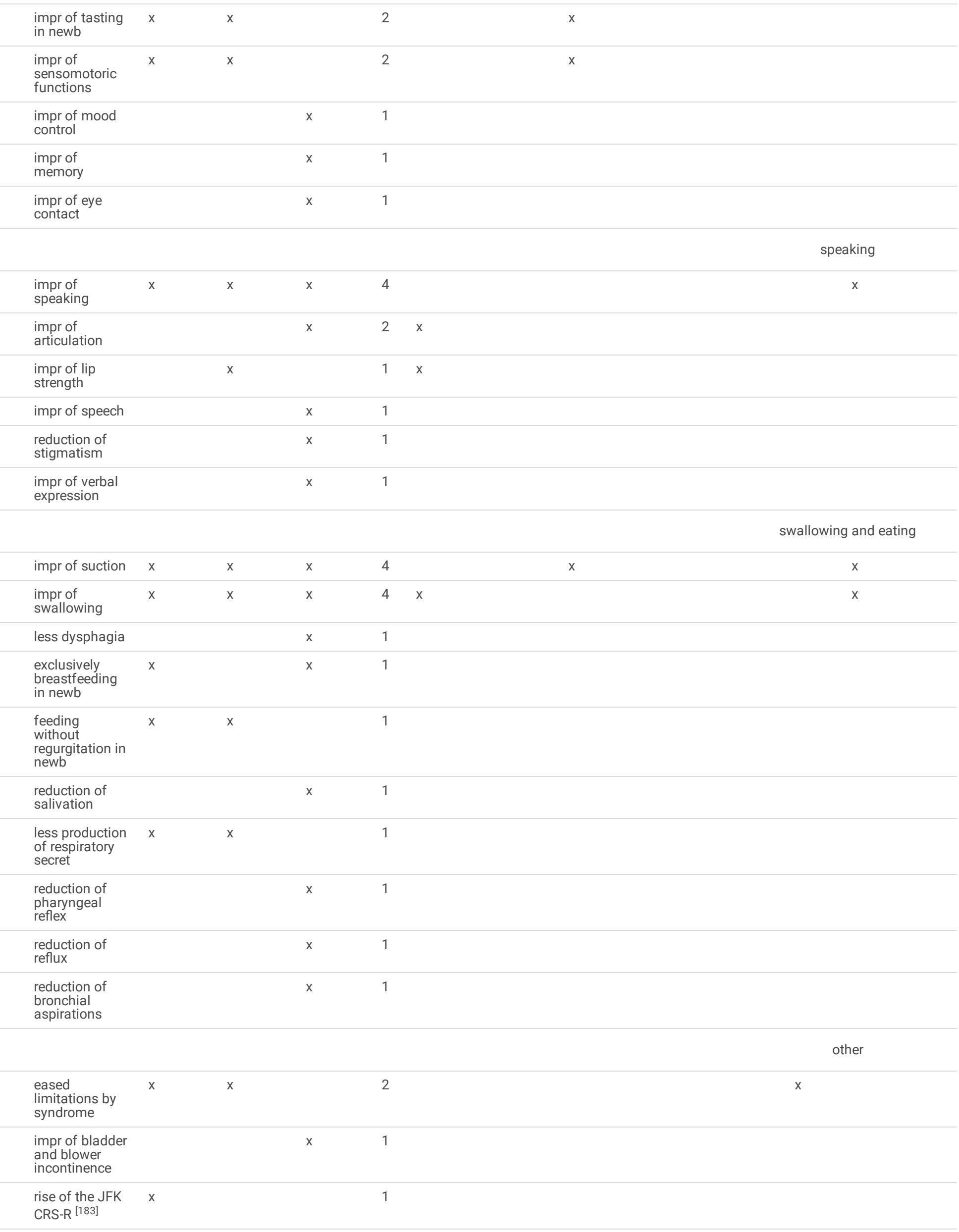




\begin{tabular}{|c|c|c|c|}
\hline $\begin{array}{l}\text { rise of the } \\
\text { WHIM }{ }^{[182]}\end{array}$ & $x$ & 1 & \\
\hline $\begin{array}{l}\text { shortening of } \\
\text { hospital stay }\end{array}$ & $x$ & 1 & $x$ \\
\hline $\begin{array}{l}\text { avoidance of } \\
\text { gastrostomy } \\
\text { and palliative } \\
\text { procedure of } \\
\text { feeding for } \\
\text { discharge of } \\
\text { the treated } \\
\text { new-borns }\end{array}$ & $x$ & 1 & $x$ \\
\hline
\end{tabular}

Notes. newb = new-born; c = in children; progr = progress; impr = improvement of motoric functions. Case Reports sorted by name of first author, items ordered in semi-logical order: psychomotor development, speaking, swallowing and eating, other and frequency of items.

Table C21. Table of secondary outcomes

$\begin{aligned} & \text { Secondary outcomes } \\ & \text { reasons for dropping out of studies }\end{aligned}$
$\begin{aligned} & n=24 \text { upper respiratory infections or recording of less than three hours } \\ & \text { of sleep [44], }\end{aligned} \begin{aligned} & n=7 \text { due to sepsis in the context of preterm } \\ & n=7 \text { due to sepsis in the context of preterm new-born [48] }\end{aligned}$
$n=6$ due to poor appointment-adherence $[36,49]$
$n=2$ transfer [48]
$n=1$ surgery [48]

Notes. Sorted by frequency. Numbers indicate the number of cases addressing the outcome. $\mathrm{NI}=$ No information provided.

Table C22. Outcomes assignment 


\begin{tabular}{|c|c|c|c|}
\hline Domain & Subdomain & Primary Outcomes & Studies \\
\hline A Motoric disfunction & $\begin{array}{l}\text { (A.i) Motoric development and } \\
\text { coordination }\end{array}$ & $\begin{array}{l}\text { impr of motoric development } \\
\text { impr of cervical control } \\
\text { impr of eye-hand-coordination } \\
\text { progr of learning to walk in c } \\
\text { impr of thoracial control } \\
\text { progr of rolling in c } \\
\text { progr of crawling in c } \\
\text { progr of sitting in c } \\
\text { watching object } \\
\text { psychomotor skills } \\
\text { impr of speaking } \\
\text { impr of articulation } \\
\text { impr of suction } \\
\text { impr of swallowing }\end{array}$ & $\begin{array}{l}\text { Pereira et al. 2015 [48] } \\
\text { Braga 2019 [51] } \\
\text { Buson 2019 [52] } \\
\text { Carmo } 2019 \text { [53] } \\
\text { Delmondes } 2018 \text { [47] } \\
\text { Froitzheim } 2010 \text { [164] } \\
\text { Großweischede 2000 } \\
\text { [165] } \\
\text { Menezes } 2019 \text { [54] } \\
\text { Oertel 2015 [36] } \\
\text { Oliveira 2019 [72] } \\
\text { Pereira 2018 [167] }\end{array}$ \\
\hline & $\begin{array}{l}\text { (A.ii) Posture and axial symmetry } \\
\text { impairment }\end{array}$ & $\begin{array}{l}\text { impr of muscle tone } \\
\text { impr of stiffness } \\
\text { impr of posture } \\
\text { impr of cervical control } \\
\text { less spasms } \\
\text { less tension and pain } \\
\text { impr of thoracial control } \\
\text { progr of sitting in c } \\
\text { impr of axial symmetry } \\
\text { reduction of bronchial aspirations }\end{array}$ & $\begin{array}{l}\text { Rodenacker } 2007 \text { [55] } \\
\text { Barbosa } 2019 \text { [50] } \\
\text { Carmo } 2019 \text { [53] } \\
\text { Delmondes } 2018 \text { [47] } \\
\text { Froitzheim } 2010 \text { [164] } \\
\text { Großweischede } 2000 \\
\text { [165] } \\
\text { Menezes } 2019 \text { [54] } \\
\text { Oertel 2015 [36] } \\
\text { Oliveira } 2019 \text { [72] } \\
\text { Pereira 2018 [167] }\end{array}$ \\
\hline
\end{tabular}




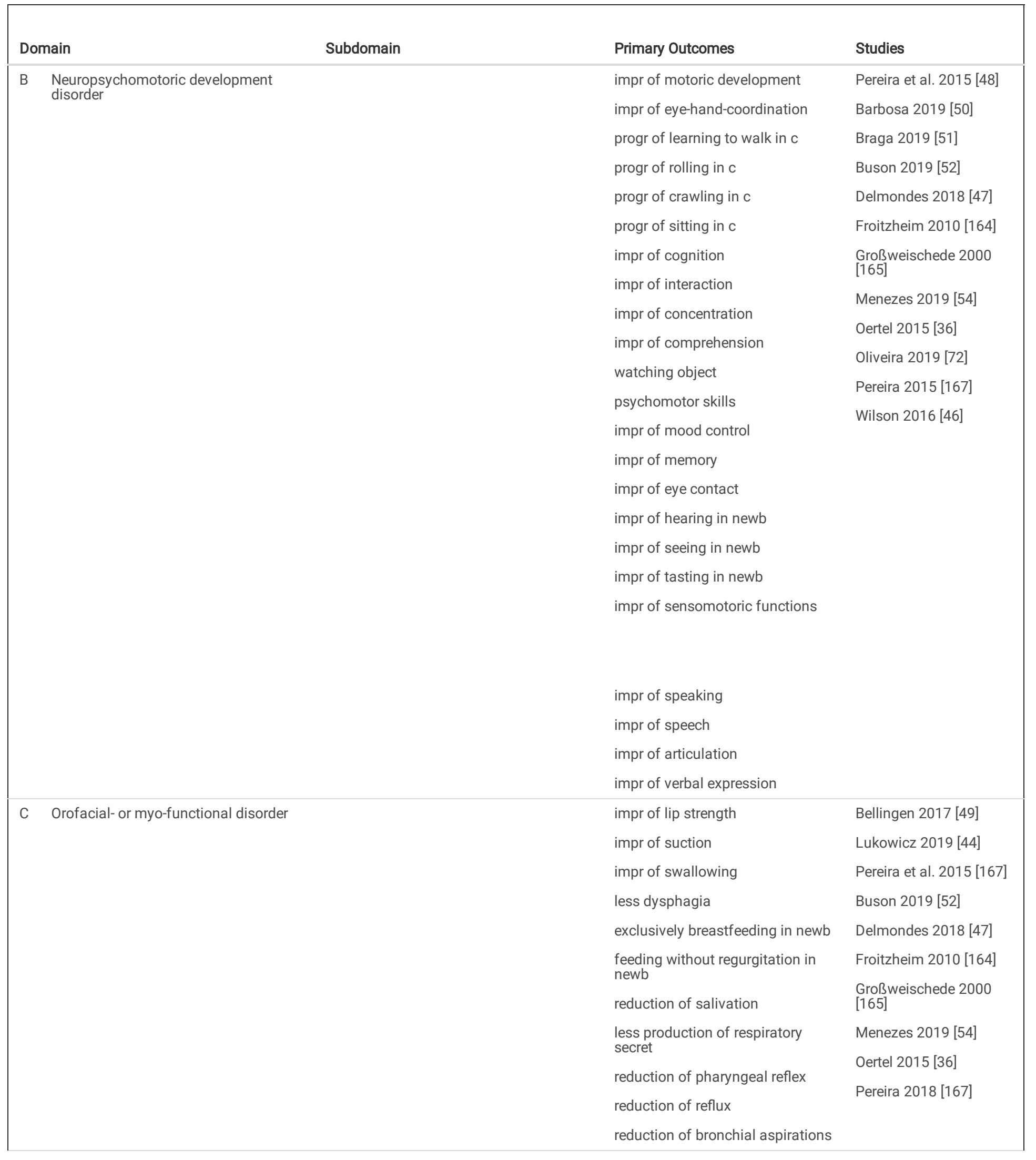




\begin{tabular}{|c|c|c|c|}
\hline \multicolumn{2}{|c|}{ Domain } & Primary Outcomes & Studies \\
\hline \multirow{6}{*}{\multicolumn{2}{|c|}{ D Speech or articulation difficulties }} & impr of speaking & Bellingen 2017 [49] \\
\hline & & impr of lip strength & Buson 2019 [52] \\
\hline & & impr of speech & Delmondes 2018 [47] \\
\hline & & impr of articulation & Froitzheim 2010 [164] \\
\hline & & reduction of stigmatism & $\begin{array}{l}\text { Großweischede } 2000 \\
\text { [165] }\end{array}$ \\
\hline & & impr of verbal expression & Wilson 2016 [46] \\
\hline
\end{tabular}

Notes. newb = new-born = in children; progr = progress; $\mathrm{impr}=$ improvement of motoric functions

Table C23. Target group 


\section{PICOT domain Changes}

$P$
Patient/Population

In any patients regardless sex and age patients with either one of the following conditions or any combination:

Disorders of the motoric system

cerebral palsy a,b,c

global and fine motor coordination ${ }^{\mathrm{C}}$

dyspraxia $^{c}$

stroke ${ }^{\mathrm{C}}$

motoric dysfunction ${ }^{\mathrm{a}}$

impaired laterality $\mathrm{a,b}$

impaired orientation in space ${ }^{b}$

impaired sense of rhythm ${ }^{b}$

impaired proprioception ${ }^{\mathrm{b}}$

impaired balance ${ }^{b}$

disorders regarding the ability to uplift ${ }^{a, b}$

Disorders of speech and language

articulatory disorders in general ${ }^{a, c}$ (exchanges, omissions and substitutions of phonemes, motor and sensory aphasias, language delay, stuttering, etc. $)^{c}$

learning disorders: attention deficit ${ }^{b, c}$ and concentration ${ }^{c}$, dyslexiac ${ }^{c}$, dyscalculia ${ }^{c}$ and dysgraphiac .

with orofacial or myofunctional disorders ${ }^{a}$

oral motricity: mouth breather ${ }^{c}$, atypical swallowing ${ }^{a, b, c}$, dysphagia ${ }^{a, b, c}$ (difficulty in swallowing) and bad oral habits ${ }^{a, b, c}$, drinking or eating difficulties ${ }^{a, b}$

\section{Neuro-motor disorders and syndromes}

neurologic disorders ${ }^{a}$

degenerative nervous system diseases ${ }^{c}$

Parkinson $^{\mathrm{b}, \mathrm{c}}$

Alzheimer's $^{c}$

dementia $^{c}$

down's syndrome ${ }^{a}$

microcephalia $^{a}$

panic syndrome ${ }^{c}$

Neuropsychiatric disorders

development disorders ${ }^{a}$

autism $^{\text {b,c }}$

hyperactivity $b, c$

chronic depression ${ }^{c}$

Other

dysphagia at icu station ${ }^{c}$

tracheostoma ${ }^{b}$

coma $^{a, b, c}$

preterm- newborn $^{a}$ 
Notes. Enumeration derived from Abad Bender, 2017 [10] and Treuenfels, 2003 [21] supplemented by results of the current systematic review.

${ }^{a}$ Included studies. ${ }^{b}$ Articles identified through research process not included into the analysis but giving indication to modify the search term [10, 21]. ${ }^{c}$ Website of the umbrella organisation of the Padovan-Method® [12] .

Table C24. Updated PICOT review question

\begin{tabular}{|c|c|c|}
\hline \multicolumn{2}{|c|}{ Description } & \multirow{2}{*}{$\begin{array}{l}\text { Term } \\
\text { In newborn, children and adults patients regardless sex and age with either one of the following conditions or any combination: }\end{array}$} \\
\hline$P$ & Patient/Population & \\
\hline & & [Disorders of the motoric system] \\
\hline & & $\begin{array}{l}\text { cerebral palsy, global and fine motor coordination, dyspraxia, stroke, motoric dysfunction, impaired laterality, impaired } \\
\text { orientation in space, impaired sense of rhythm, impaired proprioception, impaired balance, disorders regarding the ability to } \\
\text { uplift }\end{array}$ \\
\hline & & [Disorders of speech and language] \\
\hline & & $\begin{array}{l}\text { articulatory disorders in general (exchanges, omissions and substitutions of phonemes, motor and sensory aphasias, language } \\
\text { delay, stuttering, etc.), learning disorders: attention deficit and concentration, dyslexia, dyscalculia and dysgraphia, with } \\
\text { orofacial or myofunctional disorders, oral motricity: mouth breather, atypical swallowing, dysphagia (difficulty in swallowing) } \\
\text { and bad oral habits, drinking or eating difficulties }\end{array}$ \\
\hline & & [Neuro-motor disorders and syndromes] \\
\hline & & $\begin{array}{l}\text { neurologic disorders, degenerative nervous system diseases, Parkinson, Alzheimer's, dementia, down syndrome, microcephalia, } \\
\text { panic syndrome }\end{array}$ \\
\hline & & [Neuropsychiatric disorders] \\
\hline & & development disorders, autism, hyperactivity, chronic depression \\
\hline & & [Other] \\
\hline & & dysphagia at icu station, tracheostoma, coma, preterm- new-born \\
\hline I & $\begin{array}{l}\text { Intervention of } \\
\text { interest }\end{array}$ & how does an application of a therapy according to the Padovan-Method $\circledast$ by trained therapists with \\
\hline C & $\begin{array}{l}\text { Comparison } \\
\text { intervention }\end{array}$ & either no intervention, alternative as state of the art or placebo intervention \\
\hline 0 & Outcome(s) & modify the existing symptoms and quality of life \\
\hline$T$ & Time & within a 6-12-month setup \\
\hline
\end{tabular}

Notes. Intervention/Therapy PICOT question according to [93] and updated according to findings of this review.

\section{Tables}

Table 1. Characteristics of the sample 


\begin{tabular}{|c|c|c|c|c|c|c|c|c|c|c|c|}
\hline Author / Year & Status & $\begin{array}{l}\text { Country / } \\
\text { Language }\end{array}$ & $\begin{array}{l}\text { Sample } \\
n\end{array}$ & $\begin{array}{l}\text { Drop } \\
\text { out }\end{array}$ & Groups & Blinding & Age & $\begin{array}{l}\text { Diagnosis/ } \\
\text { Indication }\end{array}$ & $\begin{array}{l}\text { Diagnostic } \\
\text { instruments }^{a}\end{array}$ & Design & $\begin{array}{l}\text { Duration } \\
D_{s} \text { in } \\
\text { minutes }\end{array}$ \\
\hline $\begin{array}{l}\text { Barbosa } 2019 \\
\text { [50] }\end{array}$ & publ & $\mathrm{BRA} / \mathrm{pt}$ & 1 & NR & NR & NR & $2 y$ & microcephalia & $\begin{array}{l}\text { MRI, EEG, } \\
\text { audiometry }\end{array}$ & $\mathrm{CR}$ & $\mathrm{NI}$ \\
\hline $\begin{array}{l}\text { Braga } \\
2019[51]\end{array}$ & publ & $\mathrm{BRA} / \mathrm{pt}$ & 1 & NR & NR & NR & $2 ; 2 y$ & microcephalia & $\begin{array}{l}\text { ultrasonography } \\
\text { during } \\
\text { pregnancy ( } 31 \\
\text { weeks); CT scan } \\
\text { with } 5 \text { days of } \\
\text { life }\end{array}$ & $\mathrm{CR}$ & 60 \\
\hline $\begin{array}{l}\text { Buson } \\
2019 \text { [52] }\end{array}$ & publ & BRA/pt & 1 & NR & NR & NR & $\mathrm{NI}$ & microcephalia & $\begin{array}{l}\text { collection of } \\
\text { liquor and CT } \\
\text { scan within first } \\
3 \text { days of life }\end{array}$ & $\mathrm{CR}$ & 60 \\
\hline $\begin{array}{l}\text { Carmo } \\
2019 \text { [53] }\end{array}$ & publ & $\mathrm{BRA} / \mathrm{pt}$ & 1 & NR & NR & NR & $2 ; 5 y$ & microcephalia & $\begin{array}{l}\text { ultrasonography } \\
\text { during } \\
\text { pregnancy, } \\
\text { physical } \\
\text { examining with } \\
\text { inspection, } \\
\text { palpation, } \\
\text { respiratory } \\
\text { examination, } \\
\text { test of reflex } \\
\text { actions and } \\
\text { global } \\
\text { movements }\end{array}$ & $\mathrm{CR}$ & $\mathrm{NI}$ \\
\hline $\begin{array}{l}\text { Delmondes } \\
2018 \text { [47] }\end{array}$ & publ & BRA/en & 1 & NR & NR & NR & $6 d$ & $\begin{array}{l}\text { treacher collins } \\
\text { syndrome }\end{array}$ & $\mathrm{NI}$ & CR & $\mathrm{NI}$ \\
\hline $\begin{array}{l}\text { Froitzheim } \\
2010 \text { [166] }\end{array}$ & unp & $\mathrm{NI} / \mathrm{de}$ & 1 & NR & NR & NR & $\begin{array}{l}2,4 \\
y^{b}\end{array}$ & $\begin{array}{l}\text { tetra paresis, } \\
\text { open bite }\end{array}$ & $\mathrm{NI}$ & $\mathrm{CR}$ & $\mathrm{NI}$ \\
\hline $\begin{array}{l}\text { Großweischede } \\
2000 \text { [167] }\end{array}$ & unp & GER/de & 1 & NR & NR & NR & $8 ; 9$ y & $\begin{array}{l}\text { audiogenic } \\
\text { dyslalia }\end{array}$ & patients' records & $\mathrm{CR}$ & $\mathrm{NI}$ \\
\hline $\begin{array}{l}\text { Kunert } \\
2003 \text { [168] }\end{array}$ & publ & GER/de & 1 & NR & NR & NR & $6 y$ & $\begin{array}{l}\text { speech } \\
\text { development } \\
\text { disorder }\end{array}$ & $\mathrm{NI}$ & CR & $\mathrm{NI}$ \\
\hline $\begin{array}{l}\text { Menezes } \\
2019 \text { [54] }\end{array}$ & publ & $\mathrm{BRA} / \mathrm{pt}$ & 9 & $\mathrm{NI}$ & NR & NR & $\begin{array}{l}M= \\
10 \\
\mathrm{~m} \\
S D= \\
5,4 \\
\mathrm{~m} \\
\text { Min } \\
=0 ; 3 \\
\mathrm{y} \\
\text { Max } \\
=1 ; 7 \\
\mathrm{y}\end{array}$ & microcephalia & AIMS[171] & CS & $\mathrm{NI}$ \\
\hline
\end{tabular}




\begin{tabular}{|c|c|c|c|c|c|c|c|c|c|c|c|}
\hline Author / Year & Status & $\begin{array}{l}\text { Country / } \\
\text { Language }\end{array}$ & $\begin{array}{l}\text { Sample } \\
n\end{array}$ & $\begin{array}{l}\text { Drop } \\
\text { out }\end{array}$ & Groups & Blinding & Age & $\begin{array}{l}\text { Diagnosis/ } \\
\text { Indication }\end{array}$ & $\begin{array}{l}\text { Diagnostic } \\
\text { instruments }\end{array}$ & Design & $\begin{array}{l}\text { Duration } \\
D_{s} \text { in } \\
\text { minutes }\end{array}$ \\
\hline $\begin{array}{l}\text { Oertel } \\
2015 \text { [36] }\end{array}$ & unp & GER/de & 8 & 5 & NR & none & $\begin{array}{l}M= \\
8 \mathrm{y} \\
S D= \\
8,3 \text { y } \\
\text { Min } \\
=4 \text { y } \\
\text { Max } \\
=29 \\
y\end{array}$ & $\begin{array}{l}\text { myo-functional } \\
\text { disorder }\end{array}$ & $\begin{array}{l}\text { Logopaedic } \\
\text { assessment tool } \\
\text { (,Kölner } \\
\text { Diagnostik } \\
\text { Bogen') [131, } \\
\text { 172], sheet for } \\
\text { therapeutic } \\
\text { objective } \\
\text { clarification } \\
\text { [173], results } \\
\text { and progress } \\
\text { log (IPVP [131, } \\
\text { 172]) }\end{array}$ & CS & $45-60$ \\
\hline $\begin{array}{l}\text { Oliveira } \\
2019 \text { [72] }\end{array}$ & publ & $\mathrm{BRA} / \mathrm{pt}$ & 1 & NR & NR & NR & $2 ; 4$ y & microcephalia & $\begin{array}{l}\text { ultrasonography } \\
\text { during } \\
\text { pregnancy; } \\
\text { physical } \\
\text { examining, } \\
\text { behaviour, } \\
\text { respiratory } \\
\text { examination, } \\
\text { test of reflex } \\
\text { actions and } \\
\text { global } \\
\text { movements }\end{array}$ & $\mathrm{CR}$ & 60 \\
\hline $\begin{array}{l}\text { Pereira } \\
2015 \text { [22] }\end{array}$ & publ & BRA/en & 11 & $\mathrm{NI}$ & NR & NR & $\begin{array}{l}\text { Min } \\
=5 \mathrm{~d} \\
\text { Max } \\
= \\
5 ; 12 \\
\mathrm{~m}^{\mathrm{b}}\end{array}$ & $\begin{array}{l}\text { neonatal } \\
\text { hypoxic- } \\
\text { ischemic } \\
\text { encephalopathy } \\
\text { (10), } \\
\text { neurological } \\
\text { alteration by } \\
\text { kernicterus (1) }\end{array}$ & $\mathrm{NI}$ & CS & $\mathrm{NI}$ \\
\hline $\begin{array}{l}\text { Pereira } \\
2018 \text { [169] }\end{array}$ & publ & BRA/pt & 2 & $\mathrm{NI}$ & NR & NR & $\begin{array}{l}3 ; 5 \\
m, \\
24 d\end{array}$ & $\begin{array}{l}\text { foetal alcohol } \\
\text { syndrome }\end{array}$ & $\begin{array}{l}\text { physical } \\
\text { examination }\end{array}$ & CS & $\mathrm{NI}$ \\
\hline $\begin{array}{l}\text { Wilson } \\
2016 \text { [46] }\end{array}$ & publ & GBR/en & 1 & NR & NR & NR & $28 y$ & brain injury & CT scan & $\mathrm{CR}$ & $45-60$ \\
\hline $\begin{array}{l}\text { Bellingen } \\
2017 \text { [49] }\end{array}$ & publ & GER/de & 12 & 1 & $\begin{array}{l}8 \mathrm{ig} / 4 \\
\mathrm{cg}\end{array}$ & none & $\begin{array}{l}M_{l g} \\
= \\
11.1 \\
\mathrm{y} \\
S D_{l g} \\
=2.6 \\
\mathrm{y} \\
M_{C g} \\
=8.8 \\
\mathrm{y} \\
S D_{C g} \\
=1.4 \\
\mathrm{y}\end{array}$ & $\begin{array}{l}\text { myo-functional } \\
\text { disorders }\end{array}$ & $\begin{array}{l}\text { IOPI [175], BOT- } \\
2 \text { [176], LPB } \\
\text { [177], mouth } \\
\text { strengthening } \\
\text { tool ('MFT- } \\
\text { Lippenwaage') } \\
\text { [178], therapists } \\
\text { observation } \\
\text { parental } \\
\text { questionnaire } \\
\text { [49] }\end{array}$ & pseudo-RCT & 45 \\
\hline $\begin{array}{l}\text { Lukowicz } \\
2019[44]\end{array}$ & publ & GER/en & 42 & 24 & $\mathrm{NI}$ & NR & $\begin{array}{l}M= \\
6.3 y \\
S D= \\
2.5 \\
y^{b}\end{array}$ & $\begin{array}{l}\text { down syndrome } \\
\text { with obstructive } \\
\text { sleep apnoea }\end{array}$ & $\begin{array}{l}\text { MOAH [179], } \\
\mathrm{DI}_{3 / 90}[44], \mathrm{SpO}\end{array}$ & CBA & 45 \\
\hline $\begin{array}{l}\text { Pereira et al. } \\
2015 \text { [48] }\end{array}$ & publ & BRA/en & 92 & 10 & $\mathrm{NI}$ & NR & $\begin{array}{l}\text { Min } \\
=2 \mathrm{~d} \\
\operatorname{Max} \\
= \\
102 \\
\mathrm{~d}^{\mathrm{b}}\end{array}$ & $\begin{array}{l}\text { new-borns with } \\
\text { symptoms } \\
\text { summarised as } \\
\text { alterations in } \\
\text { neurological } \\
\text { examination or } \\
\text { presenting } \\
\text { difficulties in } \\
\text { sucking }\end{array}$ & $\begin{array}{l}\text { neurological } \\
\text { examinations }\end{array}$ & $\begin{array}{l}\text { retrospective } \\
\text { self- } \\
\text { controlled } \\
\text { cohort study }\end{array}$ & $\mathrm{NI}$ \\
\hline
\end{tabular}




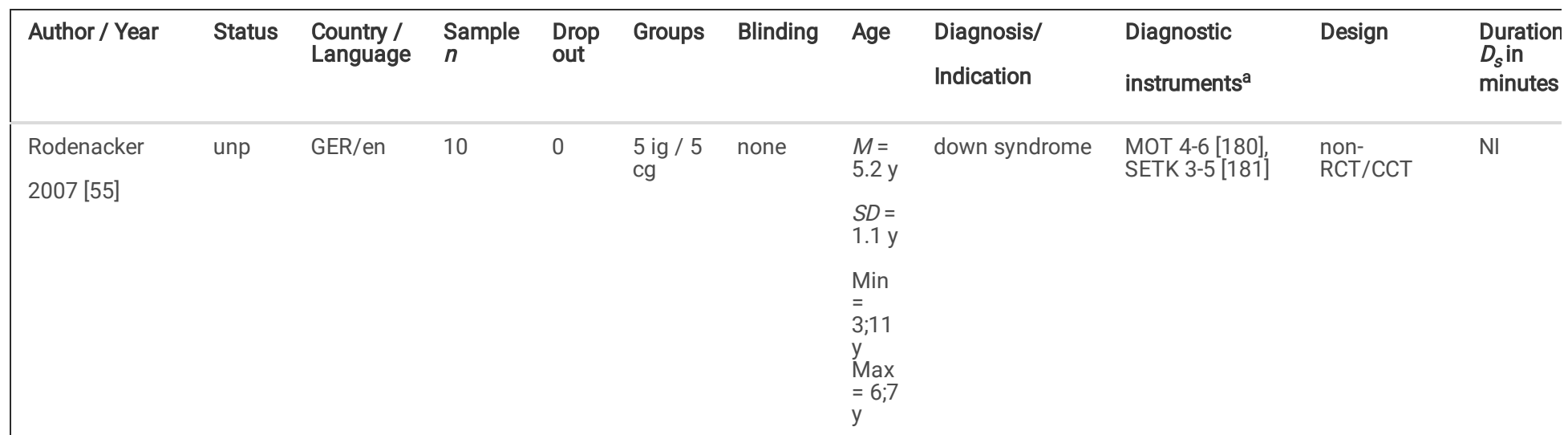

Notes. pub = published; unp = unpublished; $M=$ mean; $S D=$ standard deviation; $Y$ years; $\mathrm{m}=$ months; $\mathrm{w}=$ weeks; $\mathrm{d}=$ days; $\mathrm{BRA}=\mathrm{Brazil} ; \mathrm{GBR}=\mathrm{United}$ Kingdom of Great Britain and Northern Ireland; GER = Germany; en = English; pt = Portuguese; de = German; NI = no information given; NR = not relevant; Ig = intervention group; $\mathrm{Cg}$ = control group; $\mathrm{MRI}=$ magnetic resonance imaging; $\mathrm{CT}=$ computer tomography; $\mathrm{EEG}=$ electroencephalogram $; \mathrm{CR}=\mathrm{case}$ report; $\mathrm{CS}=$ case series; RCT = randomised controlled trial; $\mathrm{CCT}=$ controlled clinical trials; $\mathrm{q}=$ qualified; univ = university; ip = inpatient; amb = ambulatory; $\mathrm{ci}=\mathrm{co}-$ interventions; LWZ = lip-cheek-tongue trainer ('Lippen-Wangen-Zungen (LWZ)-Trainer') [174]. For main outcomes and numerical results please see Table 2.

a See Table D1 (Appendix D). ${ }^{b}$ As stated in original document.

Table 5. Adherence of the included CR and CS to the CARE-Guidelines 


\begin{tabular}{|c|c|c|c|c|c|c|c|c|c|}
\hline \multirow[t]{2}{*}{ Author / Year } & \multirow{2}{*}{$\begin{array}{l}\begin{array}{l}\text { Keywords } \\
\text { available }\end{array} \\
\begin{array}{l}\text { Keywords } \\
\text { available? }\end{array}\end{array}$} & \multicolumn{3}{|l|}{ Abstract } & \multirow{2}{*}{$\begin{array}{l}\begin{array}{l}\text { Intro- } \\
\text { duction }\end{array} \\
\begin{array}{l}\text { Background } \\
\text { of the case, } \\
\text { referencing }\end{array} \\
\text { relevant } \\
\text { medical } \\
\text { literature }\end{array}$} & \multicolumn{3}{|c|}{ Patient information } & \multirow{2}{*}{$\begin{array}{l}\begin{array}{l}\text { Clinical } \\
\text { findings }\end{array} \\
\begin{array}{l}\text { Describe the } \\
\text { relevant } \\
\text { physical }\end{array} \\
\text { examination } \\
\text { (PE) } \\
\text { findings }\end{array}$} \\
\hline & & $\begin{array}{l}\text { Introduction } \\
\text { - what does } \\
\text { this case } \\
\text { add? }\end{array}$ & $\begin{array}{l}\text { Case } \\
\text { presentation } \\
\text { (symptoms, } \\
\text { findings, } \\
\text { diagnoses, } \\
\text { intervention, } \\
\text { outcomes) }\end{array}$ & $\begin{array}{l}\text { Conclusion } \\
\text { - what } \\
\text { were the } \\
\text { main 'take- } \\
\text { away' } \\
\text { lessons? }\end{array}$ & & $\begin{array}{l}\text { Demographic } \\
\text { information } \\
\text { of the patient } \\
\text { (age, gender, } \\
\text { ethnicity, } \\
\text { occupation) }\end{array}$ & $\begin{array}{l}\text { Main } \\
\text { symptoms } \\
\text { of the } \\
\text { patient } \\
\text { (his or her } \\
\text { chief } \\
\text { complaints) }\end{array}$ & $\begin{array}{l}\text { Medical, } \\
\text { family, and } \\
\text { psychosocial } \\
\text { history - } \\
\text { including } \\
\text { diet, lifestyle, } \\
\text { and genetic } \\
\text { information } \\
\text { whenever } \\
\text { possible and } \\
\text { details about } \\
\text { relevant } \\
\text { comorbidities } \\
\text { and past } \\
\text { interventions } \\
\text { and their } \\
\text { outcomes }\end{array}$ & \\
\hline $\begin{array}{l}\text { Barbosa } 2019 \\
\text { [50] }\end{array}$ & $Y$ & PN & $\mathrm{Y}$ & $\mathrm{Y}$ & $\mathrm{Y}$ & $Y$ & $Y$ & $Y$ & $Y$ \\
\hline $\begin{array}{l}\text { Braga } 2019 \\
{[51]}\end{array}$ & $Y$ & PY & PY & PY & $\mathbf{Y}$ & $Y$ & $Y$ & $\mathrm{Y}$ & $Y$ \\
\hline $\begin{array}{l}\text { Buson } 2019 \\
\text { [52] }\end{array}$ & $\mathbf{N}$ & PY & PY & PY & $Y$ & PY & $Y$ & PY & PY \\
\hline $\begin{array}{l}\text { Carmo } 2019 \\
\text { [53] }\end{array}$ & $Y$ & PN & $Y$ & PY & $Y$ & $Y$ & $Y$ & $Y$ & PY \\
\hline $\begin{array}{l}\text { Delmondes } \\
2018 \text { [47] }\end{array}$ & $Y$ & $Y$ & $Y$ & $Y$ & PY & PY & PY & PN & $\mathbf{N}$ \\
\hline $\begin{array}{l}\text { Froitzheim } \\
2010 \text { [166] }\end{array}$ & $\mathbf{N}$ & $\mathrm{NI}$ & NI & NI & PN & PY & $Y$ & PN & $N$ \\
\hline $\begin{array}{l}\text { Großweischede } \\
2000 \text { [167] }\end{array}$ & $\mathbf{N}$ & $\mathbf{N}$ & $\mathbf{N}$ & $\mathbf{N}$ & $\mathbf{Y}$ & $\mathbf{Y}$ & $Y$ & $Y$ & $Y$ \\
\hline $\begin{array}{l}\text { Kunert } 2003 \\
\text { [168] }\end{array}$ & $\mathbf{N}$ & $\mathbf{N}$ & $\mathbf{N}$ & $\mathbf{N}$ & $\mathbf{N}$ & $\mathbf{N}$ & PY & PN & NI \\
\hline $\begin{array}{l}\text { Menezes } 2019 \\
\text { [54] }\end{array}$ & $Y$ & $\mathrm{Y}$ & $Y$ & $\mathrm{Y}$ & $\mathrm{Y}$ & $Y$ & $Y$ & $\mathbf{N}$ & PN \\
\hline $\begin{array}{l}\text { Oertel } 2015 \\
\text { [36] }\end{array}$ & $\mathbf{N}$ & $\mathbf{N}$ & $\mathbf{N}$ & $\mathbf{N}$ & $\mathrm{Y}$ & $Y$ & $Y$ & $Y$ & $Y$ \\
\hline $\begin{array}{l}\text { Oliveira } 2019 \\
\text { [72] }\end{array}$ & $Y$ & $Y$ & $Y$ & $Y$ & $\mathrm{Y}$ & $Y$ & $Y$ & $Y$ & $Y$ \\
\hline $\begin{array}{l}\text { Pereira } 2015 \\
\text { [22] }\end{array}$ & $Y$ & PY & PN & $Y$ & PY & $\mathbf{N}$ & PY & $\mathbf{N}$ & $\mathbf{N}$ \\
\hline $\begin{array}{l}\text { Pereira } 2018 \\
\text { [169] }\end{array}$ & $Y$ & PN & $Y$ & $Y$ & $Y$ & $Y$ & $Y$ & $Y$ & $Y$ \\
\hline $\begin{array}{l}\text { Wilson } 2016 \\
\text { [46] }\end{array}$ & $\mathbf{N}$ & $\mathbf{N}$ & $\mathbf{N}$ & $\mathbf{N}$ & $Y$ & $Y$ & $Y$ & $Y$ & $Y$ \\
\hline
\end{tabular}

Notes. Table according to the CARE-Guidelines [106]. $\mathbf{Y}=$ yes; $\mathbf{P Y}=$ partly yes; $\mathbf{P N}=$ partly no; $\mathbf{N}=$ no; $\mathrm{NI}=$ no information provided

Table 6. Assessment of ethics in included items 


\begin{tabular}{|c|c|c|c|c|c|c|c|c|}
\hline \multirow[t]{3}{*}{ Author / Year } & \multicolumn{5}{|l|}{$\begin{array}{l}\text { Goal related } \\
\text { considerations }\end{array}$} & \multirow{3}{*}{\begin{tabular}{|l|}
$\begin{array}{l}\text { Duty related } \\
\text { considerations }\end{array}$ \\
$\begin{array}{l}\text { Is the trial } \\
\text { published }\end{array}$ \\
\end{tabular}} & \multicolumn{2}{|l|}{$\begin{array}{l}\text { Rights related } \\
\text { considerations }\end{array}$} \\
\hline & \multicolumn{4}{|c|}{ Justification } & \multicolumn{2}{|r|}{ 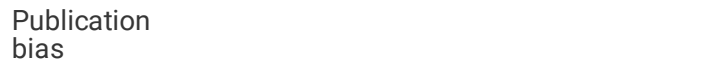 } & & Safe \\
\hline & $\begin{array}{l}\text { Is there a clear } \\
\text { declaration on } \\
\text { financial } \\
\text { support in all } \\
\text { trials? }\end{array}$ & $\begin{array}{l}\text { Is there a } \\
\text { statement } \\
\text { that } \\
\text { relates to } \\
\text { potential } \\
\text { conflicts } \\
\text { of interest } \\
\text { in all } \\
\text { trials? }\end{array}$ & $\begin{array}{l}\text { Could the } \\
\text { results have } \\
\text { been } \\
\text { obtained by } \\
\text { laboratory or } \\
\text { animal } \\
\text { experiments? }\end{array}$ & $\begin{array}{l}\text { Were any of } \\
\text { the trials } \\
\text { superfluous? }\end{array}$ & $\begin{array}{l}\text { Was the } \\
\text { size of the } \\
\text { study } \\
\text { sufficient } \\
\text { to achieve } \\
\text { adequate } \\
\text { statistical } \\
\text { power? }\end{array}$ & & $\begin{array}{l}\text { Were the } \\
\text { comparators } \\
\text { appropriate? If } \\
\text { a placebo was } \\
\text { used, was it } \\
\text { justified? }\end{array}$ & $\begin{array}{l}\text { Was } \\
\text { risk } 1 \\
\text { parti } \\
\text { appr } \\
\text { to th } \\
\text { impc } \\
\text { of th } \\
\text { rese: }\end{array}$ \\
\hline $\begin{array}{l}\text { Bellingen } 2017 \\
{[49]}\end{array}$ & $\mathbf{N}$ & $N$ & $\mathbf{N}$ & $\mathrm{PN}^{\mathrm{a}}$ & $\mathbf{N}$ & $Y$ & $Y$ & PY \\
\hline $\begin{array}{l}\text { Lukowicz } 2019 \\
\text { [44] }\end{array}$ & $Y^{b}$ & $Y^{b}$ & $\mathbf{N}$ & $P Y^{c}$ & $\mathrm{~N}$ & $Y$ & $N R^{d}$ & $\mathrm{~N}^{\mathrm{e}}$ \\
\hline $\begin{array}{l}\text { Pereira et al. } \\
2015 \text { [48] }\end{array}$ & $\mathbf{N}$ & $N$ & $\mathbf{N}$ & $\mathrm{PN}^{\mathrm{a}}$ & N & $Y$ & $N R^{d}$ & PY \\
\hline $\begin{array}{l}\text { Rodenacker } \\
2007 \text { [55] }\end{array}$ & $\mathbf{N}$ & $\mathbf{N}$ & $\mathbf{N}$ & $\mathrm{PN}^{\mathrm{a}}$ & N & $\mathbf{N}$ & $Y$ & PY \\
\hline $\begin{array}{l}\text { Barbosa } 2019 \\
{[50]}\end{array}$ & $\mathbf{N}$ & $\mathbf{N}$ & $\mathbf{N}$ & $\mathrm{PN}^{\mathrm{a}}$ & N & $Y$ & $N R^{d}$ & PY \\
\hline $\begin{array}{l}\text { Braga } 2019 \\
\text { [51] }\end{array}$ & $\mathbf{N}$ & $\mathbf{N}$ & $\mathbf{N}$ & $\mathrm{PN}^{\mathrm{a}}$ & N & $Y$ & $N R^{d}$ & PY \\
\hline $\begin{array}{l}\text { Buson } 2019 \\
\text { [52] }\end{array}$ & $\mathbf{N}$ & $N$ & $\mathbf{N}$ & $\mathrm{PN}^{\mathrm{a}}$ & N & $Y$ & $N R^{d}$ & PY \\
\hline $\begin{array}{l}\text { Carmo } 2019 \\
\text { [53] }\end{array}$ & $\mathbf{N}$ & $\mathbf{N}$ & $\mathbf{N}$ & $\mathrm{PN}^{\mathrm{a}}$ & $\mathbf{N}$ & $Y$ & $N R^{d}$ & PY \\
\hline $\begin{array}{l}\text { Delmondes } \\
2018 \text { [47] }\end{array}$ & $\mathbf{N}$ & $N$ & $N$ & $\mathrm{PN}^{\mathrm{a}}$ & N & $Y$ & $N R^{d}$ & PY \\
\hline $\begin{array}{l}\text { Froitzheim } \\
2010[166]\end{array}$ & $\mathbf{N}$ & $\mathbf{N}$ & $\mathbf{N}$ & $\mathrm{PN}^{\mathrm{a}}$ & N & $\mathbf{N}$ & $N R^{d}$ & PY \\
\hline $\begin{array}{l}\text { Großweischede } \\
2000[167]\end{array}$ & $\mathbf{N}$ & $\mathbf{N}$ & $\mathbf{N}$ & $\mathrm{PN}^{\mathrm{a}}$ & N & $\mathbf{N}$ & $N R^{d}$ & PY \\
\hline $\begin{array}{l}\text { Kunert } 2003 \\
\text { [168] }\end{array}$ & $\mathbf{N}$ & $N$ & $\mathbf{N}$ & $\mathrm{PN}^{\mathrm{a}}$ & N & $Y$ & $N R^{d}$ & PY \\
\hline $\begin{array}{l}\text { Menezes } 2019 \\
\text { [54] }\end{array}$ & $\mathbf{N}$ & $N$ & $\mathbf{N}$ & $\mathrm{PN}^{\mathrm{a}}$ & N & $Y$ & $N R^{d}$ & PY \\
\hline $\begin{array}{l}\text { Oertel } 2015 \\
\text { [36] }\end{array}$ & $\mathbf{N}$ & $N$ & $\mathbf{N}$ & $\mathrm{PN}^{\mathrm{a}}$ & N & $\mathbf{N}$ & $N R^{d}$ & PY \\
\hline $\begin{array}{l}\text { Oliveira } 2019 \\
\text { [72] }\end{array}$ & $\mathbf{N}$ & $\mathbf{N}$ & $\mathbf{N}$ & $\mathrm{PN}^{\mathrm{a}}$ & $\mathbf{N}$ & $Y$ & $N R^{d}$ & PY \\
\hline $\begin{array}{l}\text { Pereira } 2015 \\
\text { [22] }\end{array}$ & $\mathbf{N}$ & $N$ & $\mathbf{N}$ & $\mathrm{PN}^{\mathrm{a}}$ & N & $Y$ & $N R^{d}$ & PY \\
\hline $\begin{array}{l}\text { Pereira } 2018 \\
\text { [169] }\end{array}$ & $\mathbf{N}$ & $N$ & $\mathbf{N}$ & $\mathrm{PN}^{\mathrm{a}}$ & N & $Y$ & $N R^{d}$ & PY \\
\hline $\begin{array}{l}\text { Wilson } 2016 \\
\text { [46] }\end{array}$ & $\mathbf{N}$ & $\mathbf{N}$ & $\mathbf{N}$ & N & N & $Y$ & $N R^{d}$ & PY \\
\hline
\end{tabular}

Notes. Table according to [107]. $\mathbf{Y}=$ yes; $\mathbf{P Y}=$ partly yes; $\mathrm{PN}=$ partly no; $\mathbf{N}=$ no; $\mathrm{NI}=$ no information provided; $\mathrm{NR}=$ not relevant.

${ }^{a}$ Not superfluous, but reporting has methodological flaws. ${ }^{b}$ None declared. ${ }^{c}$ The intervention protocol was set up too short and known in advance as described by the authors. ${ }^{d}$ No control group. ${ }^{e}$ Study period too short and too intensive leading to inappropriate burden for the patients. ${ }^{f}$ Stated by the author as not to necessary. ${ }^{9}$ Status of patient was coma when treatment was applied.

Table 7. GRADE evidence profile for conditions I-IV: condition improvement or alleviation of symptoms 


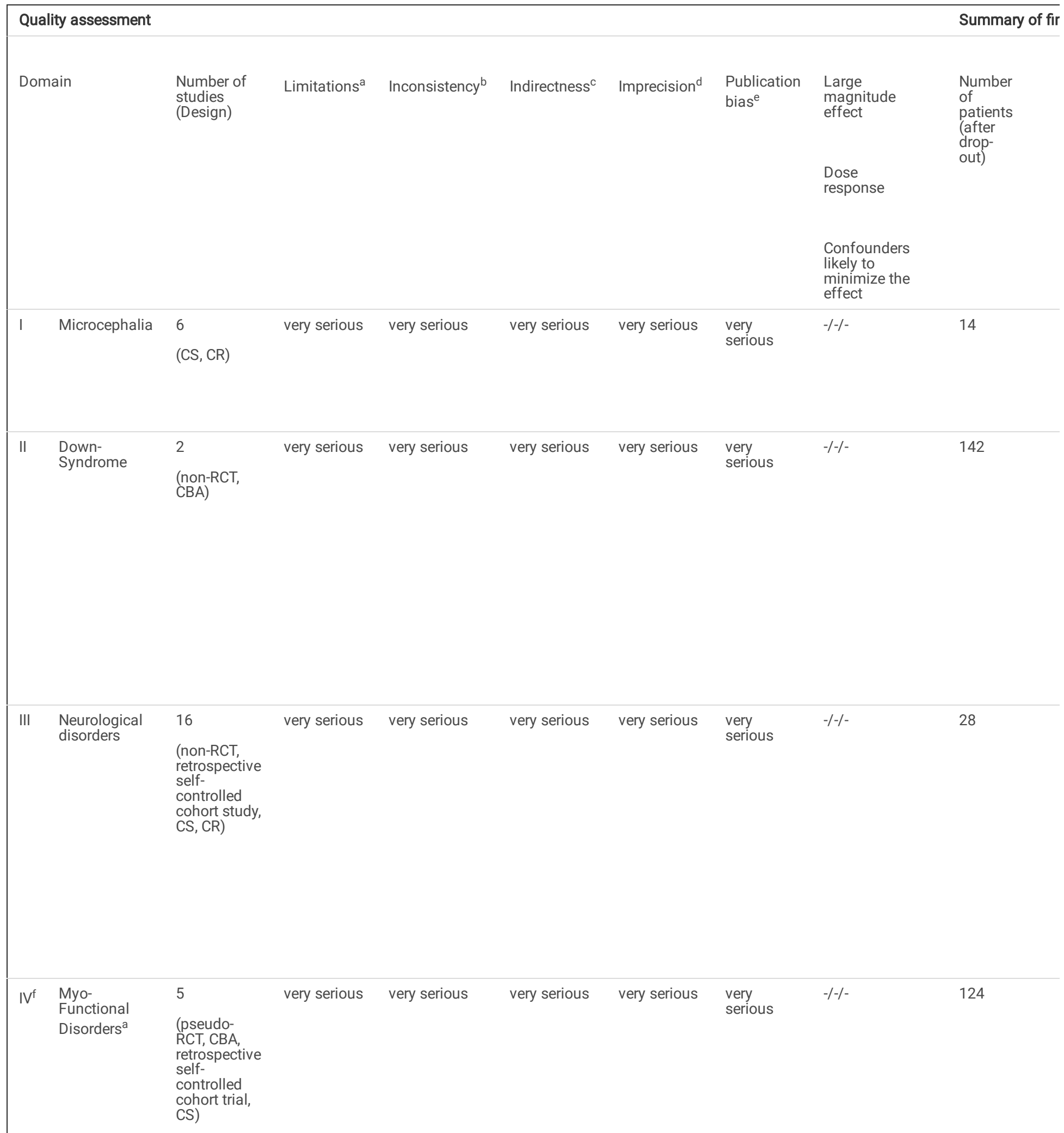


Page 55/66 
Notes. GRADE rates decrease for limitations, inconsistency, indirectness, imprecision and publication bias (serious -1 , very serious - 2 ), and increase in case of large magnitude, dose response or if confounders likely to minimize the effect. The lowest assessment of each set of studies was used.

aSee results chapter and Tables 3 and 5 for details. ${ }^{b}$ High heterogeneity in participants and inclusion criteria. ${ }^{c}$ Differences in study population, intervention protocol, outcome measurements. ${ }^{\mathrm{d}}$ No precise outcome measurements available in the majority of each set of studies. ${ }^{\mathrm{e}}$ Reporting bias likely as documentation of outcomes and follow-up were poor in the majority of each set of studies. ${ }^{f}(\mathrm{IV})$ is included in (C) (see Table 8).

Table 8. GRADE evidence profile for outcomes $A-D$ 


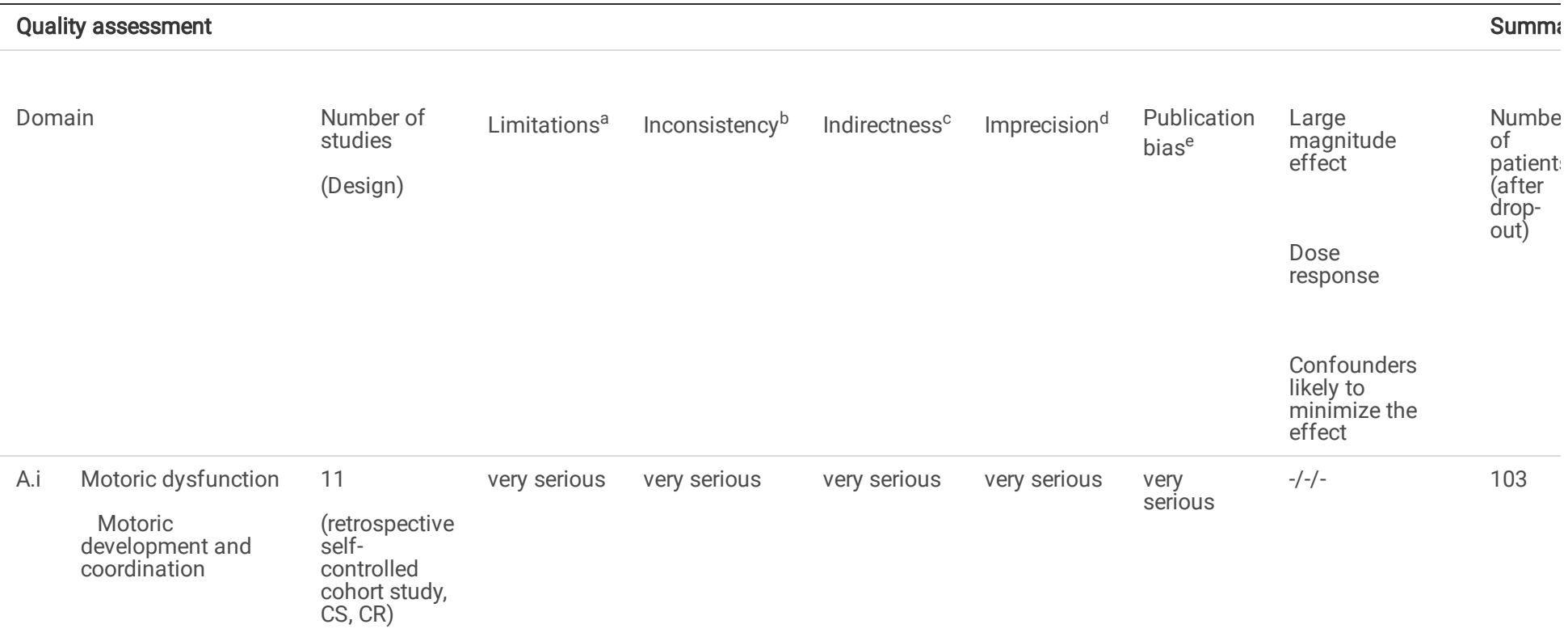

$\begin{array}{lllllll}\text { A.ii } \begin{array}{c}\text { Posture and axial } \\ \text { symmetry } \\ \text { impairment }\end{array} & 10 & \text { very serious } & \text { very serious } & \text { very serious } & \text { very serious } & \text { very } \\ \text { (non-RCT, CS, } & & & & \text { serious } & & \end{array}$

\begin{tabular}{|c|c|c|c|c|c|c|c|c|}
\hline $\begin{array}{l}\text { Neuropsychomotoric } \\
\text { development } \\
\text { disorder }\end{array}$ & $\begin{array}{l}12 \\
\text { (retrospective } \\
\text { self- } \\
\text { controlled } \\
\text { cohort study, } \\
\text { CS, CR) }\end{array}$ & very serious & very serious & very serious & very serious & $\begin{array}{l}\text { very } \\
\text { serious }\end{array}$ & $-/-1$ & 113 \\
\hline
\end{tabular}




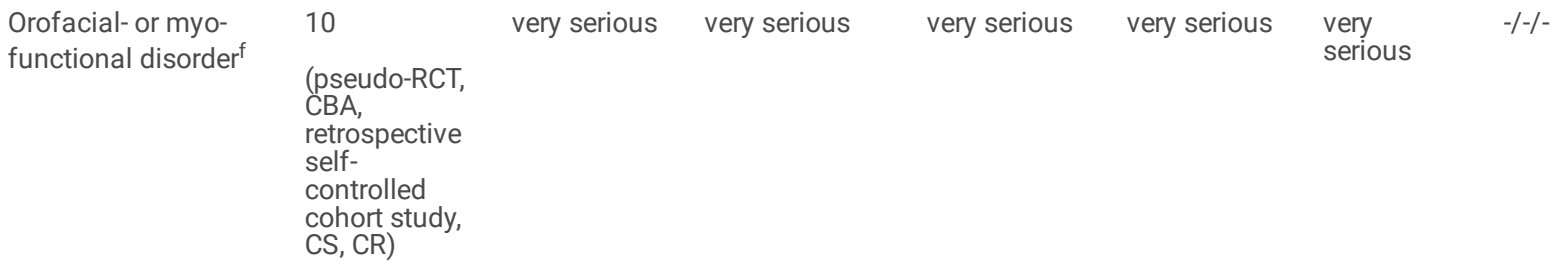


Notes. GRADE rates decrease for limitations, inconsistency, indirectness, imprecision and publication bias (serious -1 , very serious -2), and increase in case of large magnitude, dose response or if confounders likely to minimize the effect. The lowest assessment of each set of studies was used.

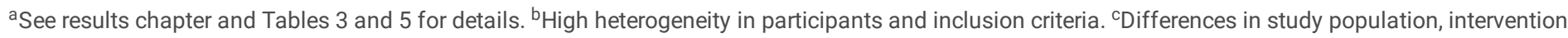
protocol, outcome measurements. ${ }^{\mathrm{d}}$ No precise outcome measurements available in the majority of each set of studies. ${ }^{\mathrm{e}}$ Reporting bias likely as

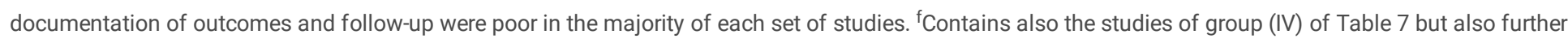
studies.

Table 9. Summary of findings - patients with microcephalia

\section{Therapy according to Padovan-Method for patients with microcephalia}

Patient or population: In newborn, children and adults patients regardless sex and age(i) in a neuro-rehabilitative setting due to neuropsychomotoric disfunctions or development disorders OR (ii) with orofacial or myofunctional disorders OR (iii) with any other not yet listed diagnosis

\section{Settings: ambulatory, inpatients}

Intervention: Therapy sessions according to Padovan-Method®

\begin{tabular}{|c|c|c|c|c|c|c|}
\hline \multirow[t]{2}{*}{ Outcomes } & \multicolumn{2}{|l|}{$\begin{array}{l}\text { Estimated } \\
\text { comparative } \\
\text { risks } \\
(95 \% \mathrm{Cl})\end{array}$} & \multirow[t]{2}{*}{$\begin{array}{l}\text { Relative } \\
\text { effect } \\
(95 \% \mathrm{Cl})\end{array}$} & \multirow[t]{2}{*}{$\begin{array}{l}\text { No of } \\
\text { participants } \\
\text { (studies) }\end{array}$} & \multirow[t]{2}{*}{$\begin{array}{l}\text { Quality of } \\
\text { evidence } \\
\text { (GRADE) }\end{array}$} & \multirow[t]{2}{*}{ Comment } \\
\hline & Control risk & Intervention risk & & & & \\
\hline $\begin{array}{l}\text { Response to treatment } \\
\text { Condition } \\
\text { improvement or } \\
\text { alleviation of } \\
\text { symptoms }\end{array}$ & $\begin{array}{l}\text { No study } \\
\text { had a } \\
\text { control } \\
\text { group }\end{array}$ & Not estimable ${ }^{a}$ & $\begin{array}{l}\text { Not } \\
\text { estimable }^{a}\end{array}$ & $14(6)$ & very low ${ }^{b}$ & \\
\hline \multicolumn{7}{|l|}{ Follow-up: } \\
\hline \multicolumn{7}{|l|}{2 months to 1 year } \\
\hline $\begin{array}{l}\text { Death due to } \\
\text { intervention side } \\
\text { effects }\end{array}$ & $\begin{array}{l}\text { See } \\
\text { comment }\end{array}$ & See comment & $\begin{array}{l}\text { Not } \\
\text { estimable }^{\mathrm{c}}\end{array}$ & - & $\begin{array}{l}\text { See } \\
\text { comment }\end{array}$ & $\begin{array}{l}\text { No study reported on this } \\
\text { outcome }\end{array}$ \\
\hline Quality of life & $\begin{array}{l}\text { No study } \\
\text { had a } \\
\text { control } \\
\text { group }\end{array}$ & $\begin{array}{l}\text { improvements of quality of life } \\
\text { described qualitatively in some } \\
\text { studies }\end{array}$ & $\begin{array}{l}\text { Not } \\
\text { estimable }\end{array}$ & - & low & $\begin{array}{l}\text { Improvements of quality of } \\
\text { life described qualitatively in } \\
\text { some studies }\end{array}$ \\
\hline $\begin{array}{l}\text { Acceptability of } \\
\text { treatment }\end{array}$ & NR & 0 from $1000(0)$ & NR & $14(6)$ & moderate $e^{b, d, e}$ & \\
\hline $\begin{array}{l}\text { Drop-out for any } \\
\text { reason }\end{array}$ & & & & & 0000 & \\
\hline \multicolumn{7}{|l|}{ Follow-up: } \\
\hline \multicolumn{7}{|l|}{2 months to 1 year } \\
\hline Overall tolerability & NR & 0 from $1000(0)$ & NR & $14(6)$ & moderate $\mathrm{b}^{\mathrm{b}, \mathrm{e}}$ & \\
\hline $\begin{array}{l}\text { Drop-out due to } \\
\text { adverse events }\end{array}$ & & & & & 0000 & \\
\hline \multicolumn{7}{|l|}{ Follow-up: } \\
\hline 2 months to 1 year & & & & & & \\
\hline
\end{tabular}


Notes. GRADE Working Group grades of evidence. See Table B2 (Appendix B) for details. NR = not relevant.

${ }^{a}$ Outcomes were mainly qualitatively described or statistical outcomes had serious inconsistency, indirectness and risk of publication bias. ${ }^{b}$ Methodological weakness of study design, unclear intervention protocol, poor outcome statistics. ${ }^{c}$ Not a single study reported on this outcome. ${ }^{\mathrm{d}}$ Acceptability of treatment was measured indirectly by the number of participants leaving the studies prematurely. ${ }^{e}$ Due to small sample size.

Table 10. Summary of findings - patients with down syndrome

\section{Therapy according to Padovan-Method for patients with down-syndrome}

Patient or population: In newborn, children and adults patients regardless sex and age (i) in a neuro-rehabilitative setting due to neuropsychomotoric disfunctions or development disorders OR (ii) with orofacial or myofunctional disorders OR (iii) with any other not yet listed diagnosis

\section{Settings: ambulatory, inpatients}

Intervention: Therapy sessions according to Padovan-Method $B$

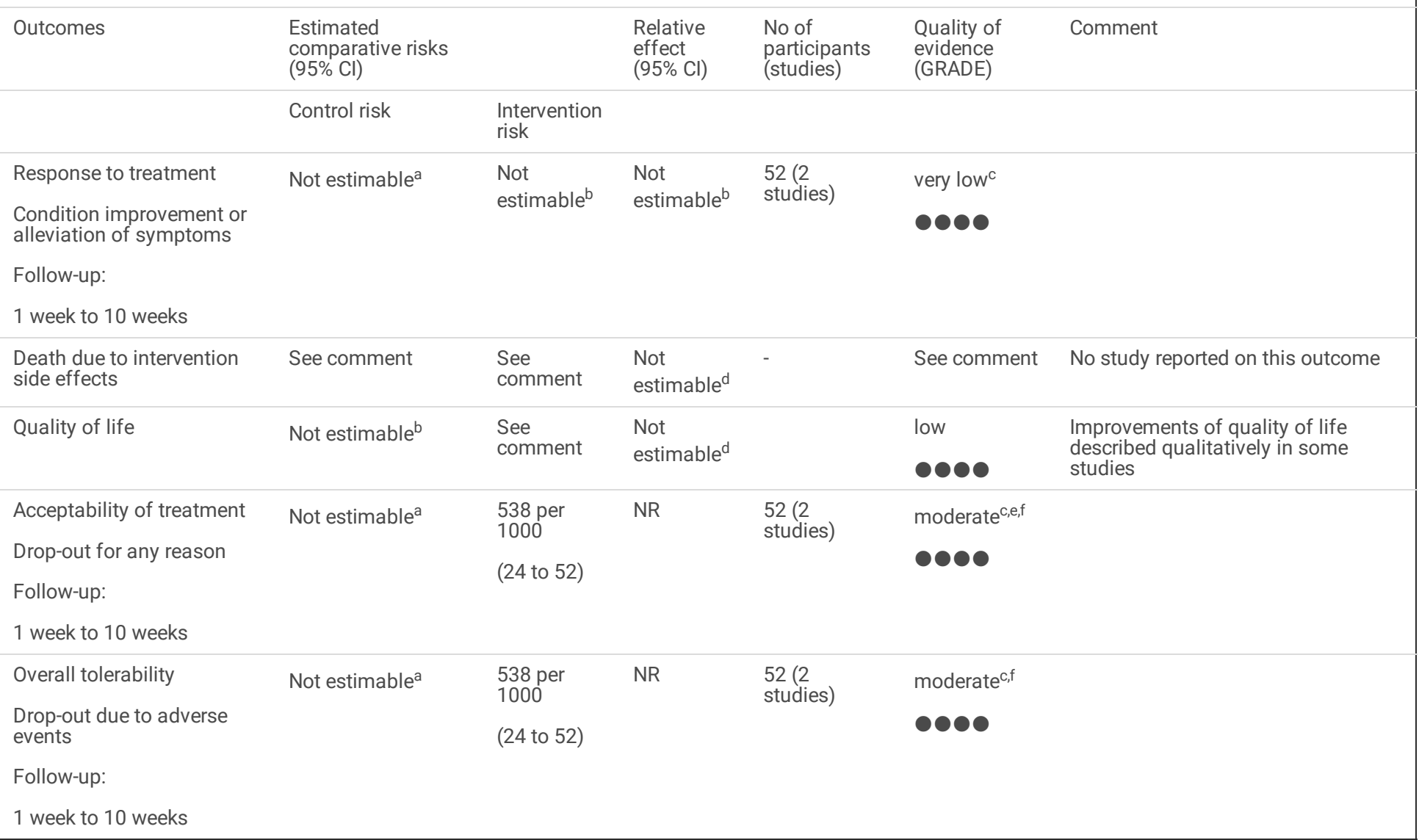

Notes. GRADE Working Group grades of evidence. See Table B2 (Appendix B) for details. NR = not relevant.

${ }^{\mathrm{a}} \mathrm{A}$ control group was not available to all included items. ${ }^{\mathrm{b}}$ Outcomes were mainly qualitatively described or statistical outcomes had serious inconsistency, indirectness and risk of publication bias. ${ }^{c}$ Methodological weakness of study design, unclear intervention protocol, poor outcome statistics. ${ }^{\mathrm{d}}$ Not a single study reported on this outcome. ${ }^{e}$ Acceptability of treatment was measured indirectly by the number of participants leaving the studies prematurely. ${ }^{f} D u e$ to small sample size.

Table 11. Summary of findings - patients with neurological disorders 


\begin{tabular}{|c|c|c|c|c|c|c|}
\hline \multicolumn{7}{|c|}{$\begin{array}{l}\text { Patient or population: In newborn, children and adults patients regardless sex and age (i) in a neuro-rehabilitative setting due to neuropsychomotoric } \\
\text { disfunctions or development disorders OR (ii) with orofacial or myofunctional disorders OR (iii) with any other not yet listed diagnosis }\end{array}$} \\
\hline \multirow{2}{*}{\multicolumn{7}{|c|}{$\begin{array}{l}\text { Settings: ambulatory, inpatients } \\
\text { Intervention: Therapy sessions according to Padovan-Method® }\end{array}$}} \\
\hline & & & & & & \\
\hline \multirow[t]{2}{*}{ Outcomes } & $\begin{array}{l}\text { Estimated } \\
\text { comparative risks } \\
(95 \% \mathrm{Cl})\end{array}$ & & $\begin{array}{l}\text { Relative } \\
\text { effect } \\
(95 \% \mathrm{Cl})\end{array}$ & $\begin{array}{l}\text { No of } \\
\text { participants } \\
\text { (studies) }\end{array}$ & $\begin{array}{l}\text { Quality of } \\
\text { evidence } \\
\text { (GRADE) }\end{array}$ & Comment \\
\hline & Control risk & $\begin{array}{l}\text { Intervention } \\
\text { risk }\end{array}$ & & & & \\
\hline $\begin{array}{l}\text { Response to treatment } \\
\text { Condition improvement or } \\
\text { alleviation of symptoms }\end{array}$ & Not estimable ${ }^{\mathrm{a}}$ & $\begin{array}{l}\text { Not } \\
\text { estimable }\end{array}$ & $\begin{array}{l}\text { Not } \\
\text { estimable }^{b}\end{array}$ & $\begin{array}{l}176(16 \\
\text { studies })\end{array}$ & very low ${ }^{c}$ & \\
\hline $\begin{array}{l}\text { Follow-up: } 2 \text { days to } 2 \\
\text { years }\end{array}$ & & & & & & \\
\hline $\begin{array}{l}\text { Death due to intervention } \\
\text { side effects }\end{array}$ & See comment & $\begin{array}{l}\text { See } \\
\text { comment }\end{array}$ & $\begin{array}{l}\text { Not } \\
\text { estimable }^{d}\end{array}$ & - & $\begin{array}{l}\text { See } \\
\text { comment }\end{array}$ & No study reported on this outcome \\
\hline Quality of life & Not estimable ${ }^{b}$ & $\begin{array}{l}\text { See } \\
\text { comment }\end{array}$ & $\begin{array}{l}\text { Not } \\
\text { estimable }^{d}\end{array}$ & - & low & $\begin{array}{l}\text { Improvements of quality of life } \\
\text { described qualitatively in some } \\
\text { studies }\end{array}$ \\
\hline $\begin{array}{l}\text { Acceptability of treatment } \\
\text { Drop-out for any reason } \\
\text { Follow-up: } 2 \text { days to } 2 \\
\text { years }\end{array}$ & Not estimable & $\begin{array}{l}807 \text { per } \\
1000 \\
(34 \text { to } 176)\end{array}$ & NR & $\begin{array}{l}176(16 \\
\text { studies) }\end{array}$ & moderate ${ }^{\mathrm{c}, \mathrm{e}, \mathrm{f}}$ & \\
\hline $\begin{array}{l}\text { Overall tolerability } \\
\text { Drop-out due to adverse } \\
\text { events }\end{array}$ & Not estimable & $\begin{array}{l}807 \text { per } \\
1000 \\
(34 \text { to } 176)\end{array}$ & NR & $\begin{array}{l}176(16 \\
\text { studies })\end{array}$ & moderate ${ }^{c, f}$ & \\
\hline $\begin{array}{l}\text { Follow-up: } 2 \text { days to } 2 \\
\text { years }\end{array}$ & & & & & & \\
\hline
\end{tabular}

Notes. GRADE Working Group grades of evidence. See Table B2 (Appendix B) for details. NR = not relevant.

${ }^{a} \mathrm{~A}$ control group was not available to all included items. ${ }^{\mathrm{b}}$ Outcomes were mainly qualitatively described or statistical outcomes had serious inconsistency, indirectness and risk of publication bias. ${ }^{C}$ Methodological weakness of study design, unclear intervention protocol, poor outcome statistics. ${ }^{\mathrm{d}}$ Not a single study reported on this outcome. ${ }^{e}$ Acceptability of treatment was measured indirectly by the number of participants leaving the studies prematurely. ${ }^{f}$ Due to small sample size.

Table 12. Summary of findings - patients with motoric dysfunction 


\section{Therapy according to Padovan-Method for patients with motoric dysfunction}

Patient or population: In newborn, children and adults patients regardless sex and age (i) in a neuro-rehabilitative setting due to neuropsychomotoric disfunctions or development disorders OR (ii) with orofacial or myofunctional disorders OR (iii) with any other not yet listed diagnosis

\section{Settings: ambulatory, inpatients}

Intervention: Therapy sessions according to Padovan-Method®

\begin{tabular}{|c|c|c|c|c|c|c|}
\hline \multirow[t]{2}{*}{ Outcomes } & \multicolumn{2}{|l|}{$\begin{array}{l}\text { Estimated } \\
\text { comparative } \\
\text { risks }(95 \% \\
\mathrm{Cl})\end{array}$} & \multirow[t]{2}{*}{$\begin{array}{l}\text { Relative } \\
\text { effect } \\
(95 \% \mathrm{Cl})\end{array}$} & \multirow[t]{2}{*}{$\begin{array}{l}\text { No of } \\
\text { participants } \\
\text { (studies) }\end{array}$} & \multirow[t]{2}{*}{$\begin{array}{l}\text { Quality of } \\
\text { evidence } \\
\text { (GRADE) }\end{array}$} & \multirow[t]{2}{*}{ Comment } \\
\hline & Control risk & $\begin{array}{l}\text { Intervention } \\
\text { risk }\end{array}$ & & & & \\
\hline $\begin{array}{l}\text { Response to } \\
\text { treatment }\end{array}$ & $\begin{array}{l}\text { Not } \\
\text { estimable }\end{array}$ & $\begin{array}{l}\text { Not } \\
\text { estimable }\end{array}$ & $\begin{array}{l}\text { Not } \\
\text { estimable }\end{array}$ & $\begin{array}{l}129(13 \\
\text { studies) }\end{array}$ & very low ${ }^{c}$ & \\
\hline
\end{tabular}

Condition estimable $^{\mathrm{a}} \quad$ estimable $^{\mathrm{b}} \quad$ estimable $^{\mathrm{b}} \quad$ studies)

improvement or

alleviation of

symptoms

Follow-up: 2 days

to 2 years

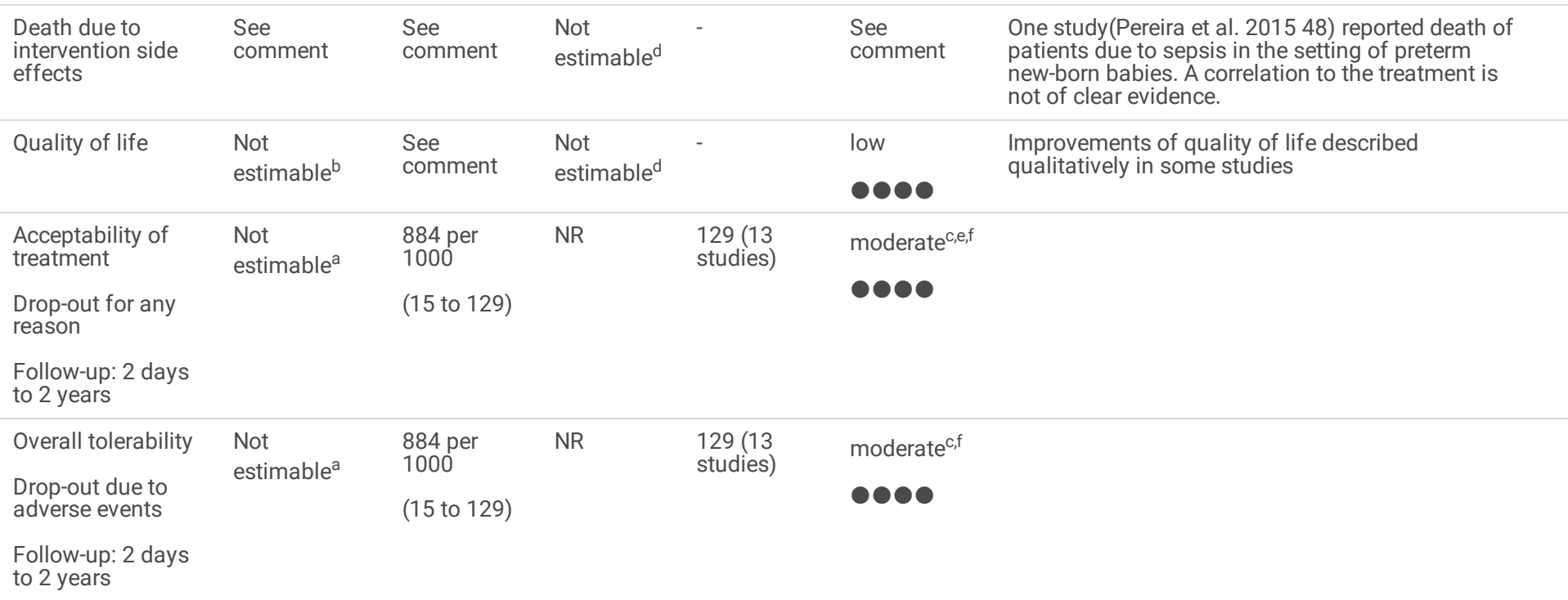

Notes. GRADE Working Group grades of evidence. See Table B2 (Appendix B) for details. NR = not relevant.

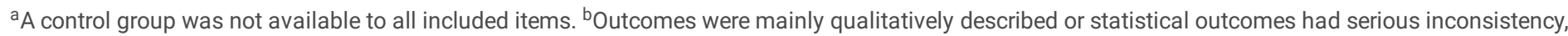
indirectness and risk of publication bias. ${ }^{C}$ Methodological weakness of study design, unclear intervention protocol, poor outcome statistics. ${ }^{\mathrm{d}} \mathrm{Not}$ a single study reported on this outcome. ${ }^{e}$ Acceptability of treatment was measured indirectly by the number of participants leaving the studies prematurely. ${ }^{f}$ Due to small sample size.

Table 13. Summary of findings - patients with neuropsychomotoric development disorder 


\begin{tabular}{|c|c|c|c|c|c|c|}
\hline \multicolumn{7}{|c|}{$\begin{array}{l}\text { Therapy according to Padovan-Method for patients with } \\
\text { neuropsychomotoric development disorder }\end{array}$} \\
\hline \multicolumn{7}{|c|}{$\begin{array}{l}\text { Patient or population: In newborn, children and adults patients regardless sex and age (i) in a neuro-rehabilitative setting due to neuropsychomotoric } \\
\text { disfunctions or development disorders OR (ii) with orofacial or myofunctional disorders OR (iii) with any other not yet listed diagnosis }\end{array}$} \\
\hline \multicolumn{7}{|c|}{ Settings: ambulatory, inpatients } \\
\hline \multicolumn{7}{|c|}{ Intervention: Therapy sessions according to Padovan-Method® } \\
\hline \multirow[t]{2}{*}{ Outcomes } & $\begin{array}{l}\text { Estimated } \\
\text { comparative } \\
\text { risks }(95 \% \mathrm{Cl})\end{array}$ & & $\begin{array}{l}\text { Relative } \\
\text { effect } \\
(95 \% \mathrm{Cl})\end{array}$ & $\begin{array}{l}\text { No of } \\
\text { participants } \\
\text { (studies) }\end{array}$ & $\begin{array}{l}\text { Quality of } \\
\text { evidence } \\
\text { (GRADE) }\end{array}$ & Comment \\
\hline & Control risk & $\begin{array}{l}\text { Intervention } \\
\text { risk }\end{array}$ & & & & \\
\hline $\begin{array}{l}\text { Response to } \\
\text { treatment }\end{array}$ & $\begin{array}{l}\text { Not } \\
\text { estimable }\end{array}$ & $\begin{array}{l}\text { Not } \\
\text { estimable }\end{array}$ & $\begin{array}{l}\text { Not } \\
\text { estimable }\end{array}$ & $128(12)$ & very low ${ }^{\mathrm{c}}$ & \\
\hline $\begin{array}{l}\text { Condition } \\
\text { improvement or } \\
\text { alleviation of } \\
\text { symptoms }\end{array}$ & & & & & 0000 & \\
\hline \multicolumn{7}{|l|}{$\begin{array}{l}\text { Follow-up: } 2 \text { days } \\
\text { to } 2 \text { years }\end{array}$} \\
\hline $\begin{array}{l}\text { Death due to } \\
\text { intervention side } \\
\text { effects }\end{array}$ & $\begin{array}{l}\text { See } \\
\text { comment }\end{array}$ & $\begin{array}{l}\text { See } \\
\text { comment }\end{array}$ & $\begin{array}{l}\text { Not } \\
\text { estimable }^{d}\end{array}$ & - & $\begin{array}{l}\text { See } \\
\text { comment }\end{array}$ & $\begin{array}{l}\text { One study(Pereira et al. } 201548 \text { ) reported death of } \\
\text { patients due to sepsis in the setting of preterm new- } \\
\text { born babies. A correlation to the treatment is not of } \\
\text { clear evidence. }\end{array}$ \\
\hline Quality of life & $\begin{array}{l}\text { Not } \\
\text { estimable }\end{array}$ & $\begin{array}{l}\text { See } \\
\text { comment }\end{array}$ & $\begin{array}{l}\text { Not } \\
\text { estimable }^{d}\end{array}$ & - & low & $\begin{array}{l}\text { Improvements of quality of life described qualitatively } \\
\text { in some studies }\end{array}$ \\
\hline $\begin{array}{l}\text { Acceptability of } \\
\text { treatment }\end{array}$ & $\begin{array}{l}\text { Not } \\
\text { estimable }\end{array}$ & $\begin{array}{l}883 \text { per } \\
1000\end{array}$ & NR & $128(12)$ & moderate ${ }^{\mathrm{c}, \mathrm{e}, \mathrm{f}}$ & \\
\hline $\begin{array}{l}\text { Drop-out for any } \\
\text { reason }\end{array}$ & & (15 to 128$)$ & & & 0000 & \\
\hline \multicolumn{7}{|l|}{$\begin{array}{l}\text { Follow-up: } 2 \text { days } \\
\text { to } 2 \text { years }\end{array}$} \\
\hline Overall tolerability & $\begin{array}{l}\text { Not } \\
\text { estimable }\end{array}$ & $\begin{array}{l}883 \text { per } \\
1000\end{array}$ & NR & $128(12)$ & moderate ${ }^{c, f}$ & \\
\hline $\begin{array}{l}\text { Drop-out due to } \\
\text { adverse events }\end{array}$ & & (15 to 128 ) & & & 0000 & \\
\hline $\begin{array}{l}\text { Follow-up: } 2 \text { days } \\
\text { to } 2 \text { years }\end{array}$ & & & & & & \\
\hline
\end{tabular}

Notes. GRADE Working Group grades of evidence. See Table B2 (Appendix B) for details. NR = not relevant.

${ }^{a}$ A control group was not available to all included items. ${ }^{b}$ Outcomes were mainly qualitatively described or statistical outcomes had serious inconsistency, indirectness and risk of publication bias. ${ }^{C}$ Methodological weakness of study design, unclear intervention protocol, poor outcome statistics. ${ }^{\mathrm{d}}$ Not a single study reported on this outcome. ${ }^{e}$ Acceptability of treatment was measured indirectly by the number of participants leaving the studies prematurely. ${ }^{f}$ Due to small sample size.

Table 14. Summary of findings - patients with orofacial or myo-functional disorders 


\begin{tabular}{|c|c|c|c|c|c|c|}
\hline \multicolumn{7}{|c|}{$\begin{array}{l}\text { Therapy according to Padovan-Method for patients with } \\
\text { orofacial or myo-functional disorders }\end{array}$} \\
\hline \multicolumn{7}{|c|}{$\begin{array}{l}\text { Patient or population: In newborn, children and adults patients regardless sex and age (i) in a neuro-rehabilitative setting due to neuropsychomotoric } \\
\text { disfunctions or development disorders OR (ii) with orofacial or myofunctional disorders OR (iii) with any other not yet listed diagnosis }\end{array}$} \\
\hline \multicolumn{7}{|c|}{ Settings: ambulatory, inpatients } \\
\hline \multicolumn{7}{|c|}{ Intervention: Therapy sessions according to Padovan-Method ${ }^{\circledR}$} \\
\hline \multirow[t]{2}{*}{ Outcomes } & $\begin{array}{l}\text { Estimated } \\
\text { comparative } \\
\text { risks }(95 \% \mathrm{Cl})\end{array}$ & & $\begin{array}{l}\text { Relative } \\
\text { effect } \\
(95 \% \mathrm{Cl})\end{array}$ & $\begin{array}{l}\text { No of } \\
\text { participants } \\
\text { (studies) }\end{array}$ & $\begin{array}{l}\text { Quality of } \\
\text { evidence } \\
\text { (GRADE) }\end{array}$ & Comment \\
\hline & Control risk & $\begin{array}{l}\text { Intervention } \\
\text { risk }\end{array}$ & & & & \\
\hline $\begin{array}{l}\text { Response to } \\
\text { treatment }\end{array}$ & $\begin{array}{l}\text { Not } \\
\text { estimable }^{a}\end{array}$ & $\begin{array}{l}\text { Not } \\
\text { estimable }^{b}\end{array}$ & $\begin{array}{l}\text { Not } \\
\text { estimable }^{b}\end{array}$ & $\begin{array}{l}169(10 \\
\text { studies) }\end{array}$ & very low ${ }^{c}$ & \\
\hline $\begin{array}{l}\text { Condition } \\
\text { improvement or } \\
\text { alleviation of } \\
\text { symptoms }\end{array}$ & & & & & 0000 & \\
\hline \multicolumn{7}{|l|}{$\begin{array}{l}\text { Follow-up: } 2 \text { days } \\
\text { to } 2 \text { years }\end{array}$} \\
\hline $\begin{array}{l}\text { Death due to } \\
\text { intervention side } \\
\text { effects }\end{array}$ & $\begin{array}{l}\text { See } \\
\text { comment }\end{array}$ & $\begin{array}{l}\text { See } \\
\text { comment }\end{array}$ & $\begin{array}{l}\text { Not } \\
\text { estimable }^{d}\end{array}$ & - & $\begin{array}{l}\text { See } \\
\text { comment }\end{array}$ & $\begin{array}{l}\text { One study(Pereira et al. } 201548 \text { ) reported death of } \\
\text { patients due to sepsis in the setting of preterm new- } \\
\text { born babies. A correlation to the treatment is not of } \\
\text { clear evidence. }\end{array}$ \\
\hline Quality of life & $\begin{array}{l}\text { Not } \\
\text { estimable }\end{array}$ & $\begin{array}{l}\text { See } \\
\text { comment }\end{array}$ & $\begin{array}{l}\text { Not } \\
\text { estimable }^{d}\end{array}$ & - & low & $\begin{array}{l}\text { Improvements of quality of life described qualitatively } \\
\text { in some studies }\end{array}$ \\
\hline $\begin{array}{l}\text { Acceptability of } \\
\text { treatment }\end{array}$ & $\begin{array}{l}\text { Not } \\
\text { estimable }\end{array}$ & $\begin{array}{l}763 \text { per } \\
1000\end{array}$ & NR & $\begin{array}{l}169(10 \\
\text { studies) }\end{array}$ & moderate ${ }^{\mathrm{c}, \mathrm{e}, \mathrm{f}}$ & \\
\hline $\begin{array}{l}\text { Drop-out for any } \\
\text { reason }\end{array}$ & & (40 to 169 ) & & & 0000 & \\
\hline \multicolumn{7}{|l|}{$\begin{array}{l}\text { Follow-up: } 2 \text { days } \\
\text { to } 2 \text { years }\end{array}$} \\
\hline Overall tolerability & Not & $\begin{array}{l}763 \text { per } \\
1000\end{array}$ & NR & $\begin{array}{l}169 \text { (10 } \\
\text { studies) }\end{array}$ & moderate ${ }^{\mathrm{c}, \mathrm{f}}$ & \\
\hline $\begin{array}{l}\text { Drop-out due to } \\
\text { adverse events }\end{array}$ & & (40 to 169 ) & & & 0000 & \\
\hline $\begin{array}{l}\text { Follow-up: } 2 \text { days } \\
\text { to } 2 \text { years }\end{array}$ & & & & & & \\
\hline
\end{tabular}

Notes. GRADE Working Group grades of evidence. See Table B2 (Appendix B) for details. NR = not relevant.

${ }^{a}$ A control group was not available to all included items. ${ }^{b}$ Outcomes were mainly qualitatively described or statistical outcomes had serious inconsistency, indirectness and risk of publication bias. ${ }^{C}$ Methodological weakness of study design, unclear intervention protocol, poor outcome statistics. ${ }^{\mathrm{d}}$ Not a single study reported on this outcome. ${ }^{e}$ Acceptability of treatment was measured indirectly by the number of participants leaving the studies prematurely. ${ }^{f}$ Due to small sample size.

Table 15. Summary of findings - patients with speech or articulation difficulties 


\begin{tabular}{|c|c|c|c|c|c|c|}
\hline \multicolumn{6}{|c|}{ Therapy according to Padovan-Method for patients with } & \\
\hline \multicolumn{7}{|c|}{$\begin{array}{l}\text { Patient or population: In newborn, children and adults patients regardless sex and age (i) in a neuro-rehabilitative setting due to neuropsychomotoric } \\
\text { disfunctions or development disorders OR (ii) with orofacial or myofunctional disorders OR (iii) with any other not yet listed diagnosis }\end{array}$} \\
\hline \multicolumn{7}{|c|}{ Settings: ambulatory, inpatients } \\
\hline \multicolumn{7}{|c|}{ Intervention: Therapy sessions according to Padovan-Method $®$} \\
\hline \multirow[t]{2}{*}{ Outcomes } & $\begin{array}{l}\text { Estimated } \\
\text { comparative risks } \\
(95 \% \mathrm{Cl})\end{array}$ & & $\begin{array}{l}\text { Relative } \\
\text { effect } \\
(95 \% \mathrm{Cl})\end{array}$ & $\begin{array}{l}\text { No of } \\
\text { participants } \\
\text { (studies) }\end{array}$ & $\begin{array}{l}\text { Quality of } \\
\text { evidence } \\
\text { (GRADE) }\end{array}$ & Comment \\
\hline & Control risk & $\begin{array}{l}\text { Intervention } \\
\text { risk }\end{array}$ & & & & \\
\hline Response to treatment & Not estimable ${ }^{a}$ & Not & Not & $\begin{array}{l}17(6 \\
\text { studies })\end{array}$ & very low ${ }^{\mathrm{c}}$ & \\
\hline $\begin{array}{l}\text { Condition improvement or } \\
\text { alleviation of symptoms }\end{array}$ & & & & & 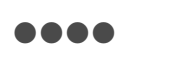 & \\
\hline \multicolumn{7}{|l|}{$\begin{array}{l}\text { Follow-up: } 5 \text { days to } 2 \\
\text { years }\end{array}$} \\
\hline $\begin{array}{l}\text { Death due to intervention } \\
\text { side effects }\end{array}$ & See comment & $\begin{array}{l}\text { See } \\
\text { comment }\end{array}$ & $\begin{array}{l}\text { Not } \\
\text { estimable }^{d}\end{array}$ & - & See comment & No study reported on this outcome \\
\hline Quality of life & Not estimable ${ }^{b}$ & $\begin{array}{l}\text { See } \\
\text { comment }\end{array}$ & $\begin{array}{l}\text { Not } \\
\text { estimable }^{d}\end{array}$ & - & $\begin{array}{l}\text { low } \\
\text { ○०॰ }\end{array}$ & $\begin{array}{l}\text { Improvements of quality of life } \\
\text { described qualitatively in some } \\
\text { studies }\end{array}$ \\
\hline Acceptability of treatment & Not estimable ${ }^{a}$ & $\begin{array}{l}941 \text { per } \\
1000\end{array}$ & NR & $\begin{array}{l}17(6 \\
\text { studies })\end{array}$ & moderate $e^{c, e, f}$ & \\
\hline Drop-out for any reason & & (1 to 17$)$ & & & $\bullet \bullet 00$ & \\
\hline $\begin{array}{l}\text { Follow-up: } 5 \text { days to } 2 \\
\text { years }\end{array}$ & & & & & & \\
\hline Overall tolerability & Not estimable ${ }^{a}$ & $\begin{array}{l}941 \text { per } \\
1000\end{array}$ & NR & $\begin{array}{l}17(6 \\
\text { studies })\end{array}$ & moderate $e^{\mathrm{c}, \mathrm{f}}$ & \\
\hline $\begin{array}{l}\text { Drop-out due to adverse } \\
\text { events }\end{array}$ & & & & & $\bullet \bullet \bullet \bullet$ & \\
\hline $\begin{array}{l}\text { Follow-up: } 5 \text { days to } 2 \\
\text { years }\end{array}$ & & & & & & \\
\hline
\end{tabular}

Notes. GRADE Working Group grades of evidence. See Table B2 (Appendix B) for details. NR = not relevant.

${ }^{\mathrm{a} A}$ control group was not available to all included items. ${ }^{\mathrm{b}}$ Outcomes were mainly qualitatively described or statistical outcomes had serious inconsistency, indirectness and risk of publication bias. ${ }^{c}$ Methodological weakness of study design, unclear intervention protocol, poor outcome statistics. ${ }^{\mathrm{d}}$ Not a single study reported on this outcome. ${ }^{\mathrm{e} A c c e p t a b i l i t y ~ o f ~ t r e a t m e n t ~ w a s ~ m e a s u r e d ~ i n d i r e c t l y ~ b y ~ t h e ~ n u m b e r ~ o f ~ p a r t i c i p a n t s ~ l e a v i n g ~ t h e ~ s t u d i e s ~ p r e m a t u r e l y . ~}{ }^{\mathrm{f}} \mathrm{Due}$ to small sample size.

\section{Figures}




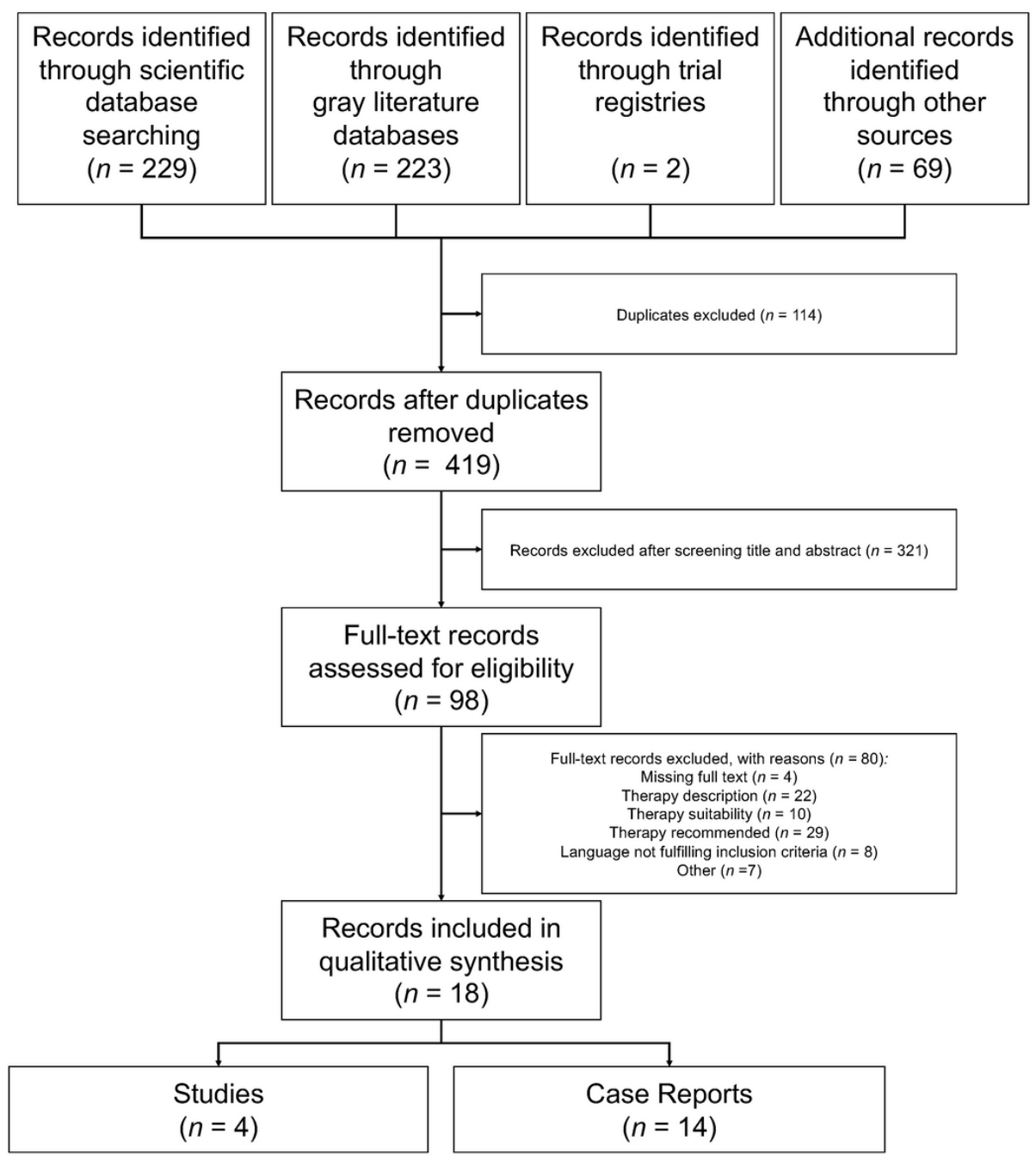

Figure 1

PRISMA Flowchart of the literature selection process

\section{Supplementary Files}

This is a list of supplementary files associated with this preprint. Click to download.

- PRISMAchecklistPadovan.docx 